\title{
Structure and chronology of Russian hunting stations on the Sørkappland and Hornsund coasts (Spitsbergen)
}

\begin{abstract}
Excavations conducted in $1982-1987$ by a Polish archaeological expedition from the Jagiellonian University in the Sørkappland and Hornsund coasts of Spitsbergen encompassed the three Pomor hunting stations of Bjørnbeinflyene, Palffyodden, and Schönningholmane, and included relics from the landing site on the Tørrflya coast used by the Pomors. The wood recovered during the excavations, originating from wooden dwellings, monumental crosses, and a shipwreck, was subjected to dendrochronological and radiocarbon analyses. The chronological position of the remaining sequences was established by means of wiggle-matching. The results suggest that the youngest rings of the larch sequence cannot be older than $\mathrm{AD} 1751$, and the youngest rings of the pine sequence date within one of three periods: AD 1718-1760, 1772-1808, or 1825-1869. Absolute dates obtained for the wood from the huts from the northern part of Sørkappland are consistent with the chronological framework established based on historical data.
\end{abstract}

Keywords: Spitsbergen, Russian hunting stations, dendrochronology, ${ }^{14} \mathrm{C}$ dating, wiggle-matching

\section{The beginnings of the Pomor promysl in the southern part of Sørkappland}

Sørkappland, the southern peninsula of Spitsbergen separated from the rest of the island by the Hornsund fiord, is the part of the Svalbard archipelago closest to the continent and most easily accessible for sailors. This is mainly due to the West Spitsbergen current, a branch of the Gulfstream flowing poleward past Sørkappland's western coast, whose warmer waters create in the Greenland Sea a "bay", reaching far to the north, which in summer is free of large icefields (Hacquebord 1984, fig. 5). When the Artic was under exploration in the $16^{\text {th }}$ and $17^{\text {th }}$ centuries, even in harsher climatic conditions of the Little Ice $\mathrm{Age}^{3}$, the accessibility of these

1 Institute of Archaeology, Jagiellonian University; 11 Gołębia St., 31-007 Kraków, Poland; j.chochorowski@uj.edu.pl

${ }^{2}$ Faculty of Geology, Geophysics and Environmental Protection, AGH - University of Science and Technology; Al. Mickiewicza 30, 30-059 Kraków, Poland; mkrapiec@agh.edu.pl

${ }^{3}$ In Scandinavia its peak came in the second half of the $17^{\text {th }}$ and first half of the $18^{\text {th }}$ century (Grove 1988, 64-107), with a particularly harsh episode in the 1660s and 1670s (Kotljakov, Gordienko 1982, 236). 
waters allowed sailors to travel much further north than in other Arctic regions (Chochorowski 2002, 87). It was exactly in this region where the first historically attested landing of Western European sailors took place on the shores of the "New Land" ("Nieuve land"), as Svalbard was known after its discovery by Willem Barents in 1596 (Hacquebord 1981). The credit goes to the crew of the Amitie, a small 70-ton ship of the London-based Muscovy Company under the command of Captain Jonas Pool, who came ashore on the $6^{\text {th }}$ of May, 1610. Approaching from the direction of Bear Island, the sailors first noticed a tall mountain, which they named MuscovyCompany's Mount (today Horsundtind - $1431 \mathrm{~m}$ a.s.1.) ${ }^{4}$, and after four more miles the entrance to a fiord. When the crew of a boat sent to the shore returned with a reindeer antler, the fiord was given the name Horn Sound (Conway 1906, 33). Soon afterwards (from 1613), Hornsund became the place of intensive whaling operations, carried out by first Dutch and later mainly English whalers (Chochorowski 1989, 21-42; 2008, 246). The testimony of this activity are ruins of a large whaling station (remains of kilns used for boiling whale blubber into oil, ruins of stone houses, and graves covered with stone pavements) in Gåshamna Bay (Chochorowski 1989, figs 1-6; Helberg 1998, 47-48), along with single features (remains of a kiln for boiling blubber, ruins of a house, graves, and a look-out) in the Höferpynten-Hansenodden/Schönningholmane complex (Chochorowski 1989, fig. 9; 1989a, 183-208), on the southern side of the Hornsund mouth.

To a certain degree, the milder climate also favoured the sailing operations of Russian walrus hunters from the coasts of the White Sea (known as the Pomors), who - perhaps - visited these waters even before Barents (Heintz 1966, 93-118)5. The discussion on possible "Pre-Barents" activity of the Pomors in Spitsbergen ${ }^{6}$ waters became particularly vivid after Russian scholars published dendrochronological dates from the remains of Pomor hunting stations on Spitsbergen's southern and western coasts (Fig. 1). Five sites (Gravsjøn = 1593 AD, Stabbelva $=1589$ AD, Mosvatnet $2=1588$ AD, Sørneset $=1563$ AD, and Gravsjøn $1=1548$ AD) produced dates falling in the middle and second half of the $16^{\text {th }}$ century (Starkov, Korjakin, Zav'jalov 1983, 110; Chernykh 1987, 252-259; 1990, 107-123; 1996, 159, pl. 6; Starkov 1987, 236-241; 1990, 124-133; 1998, pl. 3, 47-58). Two of these stations: Sørneset and Mosvatnet 2 in Sørkappøya (dated to "1563" and "1588" respectively ${ }^{7}$ ) are situated on the southern end of Sørkappland

\footnotetext{
${ }^{4}$ On Hessel Garritsz's Niev lant dit Spitsberghe map from 1613 it features as Moscovit Mont (Schilder 1988, fig. 15).

${ }^{5}$ The publication discusses historic arguments quoted in various studies by Russian and Soviet archaeologists, which in their opinion argue for the presence of Russian sailors on Spitsbergen (Gruland/Grumant - Heintz 1966, 94-106) waters prior to the Barent's discovery. However, it should be clearly emphasised that the knowledge of these waters and the awareness of the existence of land in this part of the Arctic is not tantamount to undertaking by Russian sailors (the Pomors) of hunting activity in this area. The successful application of hunting strategies developed by the Pomors in the White Sea and Nova Zemlja required information on conditions specific to Svalbard Archipelago, which they could collect either during their own "pioneering" (perhaps even accidental) journeys, or from other (e.g. West European) sailors. In the latter context one should take into account in particular the information from the shipwreck survivors from the Barent's expedition who, after wintering in Nova Zemlja, returned home via Kola Peninsula (Hacquebord 1981, 16; Braat, 1984, 474).

${ }^{6}$ See e.g. Albrethsen, Arlov 1988, 105-110; Starkov 1988, 111-116; Chernikh 1988, 117-118; Chochorowski 1992, 53-62; 1999, 71-90; Jasinski 1993, 191-266; Starkov 1998, 46-58; Hultgreen 2000, $41-73$ and $256-284$.

${ }^{7}$ The dates quoted after: Starkov 1998, pl. 3 and 4. In V. F. Starkov's publication from 1990 (pl. I) they figure as "1586" (as "Mosvatnet 2a") and "1561". In turn, in her publication from 1987 N. B. Chernykh (pl. II) presents the dates as "1558", and "1545" and "1562" (i.e. two dates for the second of the sites in
} 


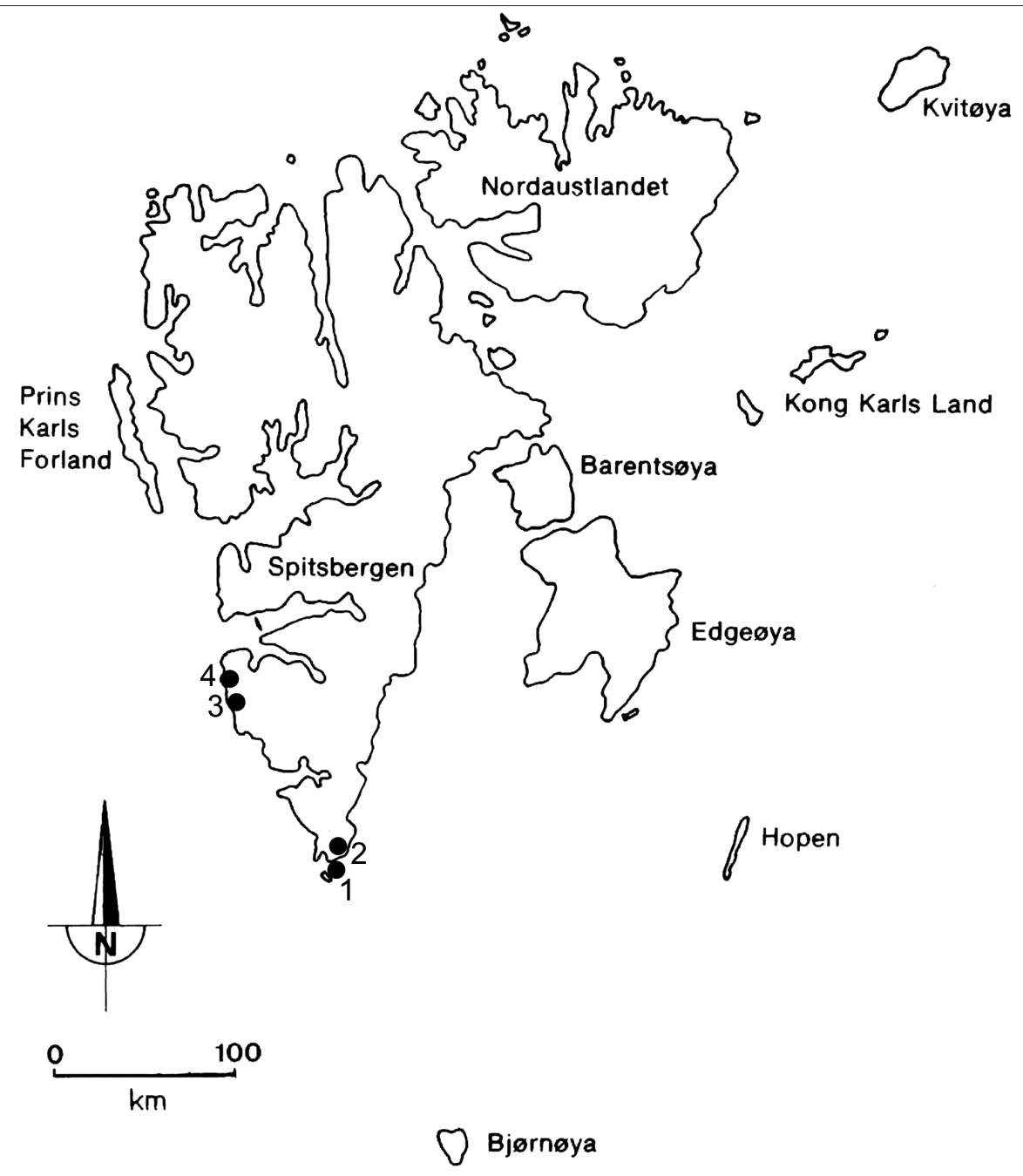

Fig. 1. Russian hunting stations in south and west coasts on Spitsbergen which according to V. F. Starkov are dated dendrochronologically to the $16^{\text {th }}$ century: 1 - Mosvatnet, 2 - Sørneset, 3 - Gravsjøn (residential chamber and bath), 4 - Stabbelva

(Fig. 2), which means close to the sailing routes leading from the Barents Sea and from the direction of Bear Island ${ }^{8}$. Furthermore, from Sørkappland and the Hornsund fiord, relics of other Russian stations are known as well, which also date quite early, namely to the first half of the $17^{\text {th }}$

question), while in her study from 1990 (p. 117) as "1588", and "1547" and "1563" (?!). Furthermore, in the latter study one can find (Chernykh 1990, 117) a date of "1565" for the Sørkappvatnet site in Sørkappøya (repeated as "Sørkappvatnet a" in: Starkov 1990, pl. I), which is lacking in the publications by the same author from 1987 and 1996, and in V. F. Starkov's publication from 1998.

${ }^{8}$ In the opinion of Russian scholars (Zav'jalov, Starkov 1987, 247), Sørkappøya was one the regions where Pomor hunting operations (known as promysl) started the earliest in Svalbard. 


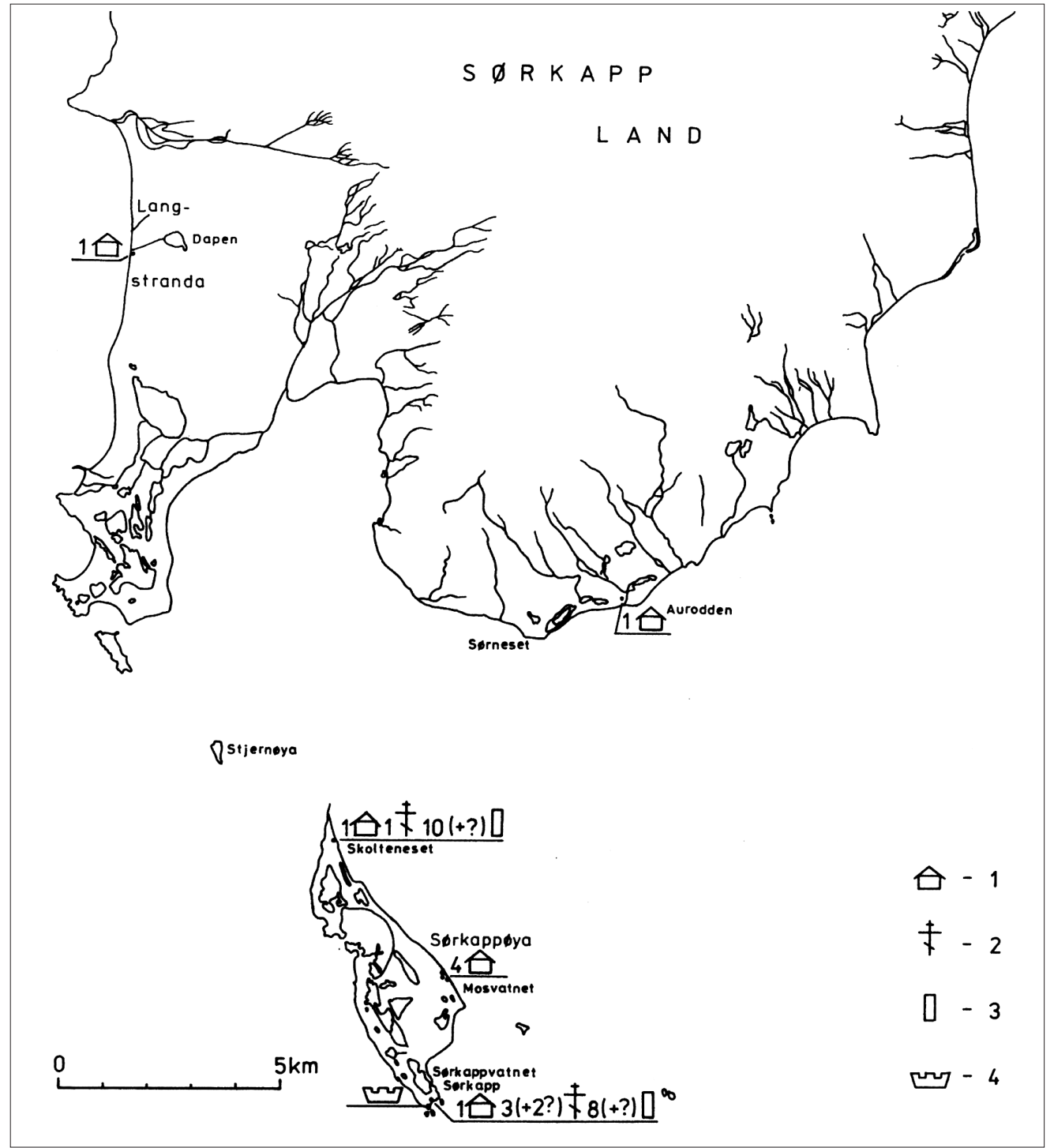

Fig. 2. Remains of Russian hunting stations in the southern part of Sørkappland; 1 - remains of buildings, 2 - remains of monumental crosses, 3 - graves, 4 - whalers' observation post (look-out). Numerals accompanying signatures indicate the number of features

century (Starkov 1998, pl. 3-4, fig. 36). These are: Langstranda (“1621” - Chernykh 1990, 117; Starkov 1998, pl. 4) $)^{9}$ to the south of the Olsokbreen glacier in the southern part of Sørkappland, and Ariebukta at the mouth of the Revelva River, on the northern side of the Hornsund mouth

\footnotetext{
${ }^{9}$ In Starkov 1990, pl. I, the site is given the date of "1630", while in Chernykh 1987, pl. 2 it probably figures as "Sørkappland - 1621?", and in a summary list published in 1996 (Chernykh 1996, 159, pl. 6) as "Langstrand - 1621".
} 


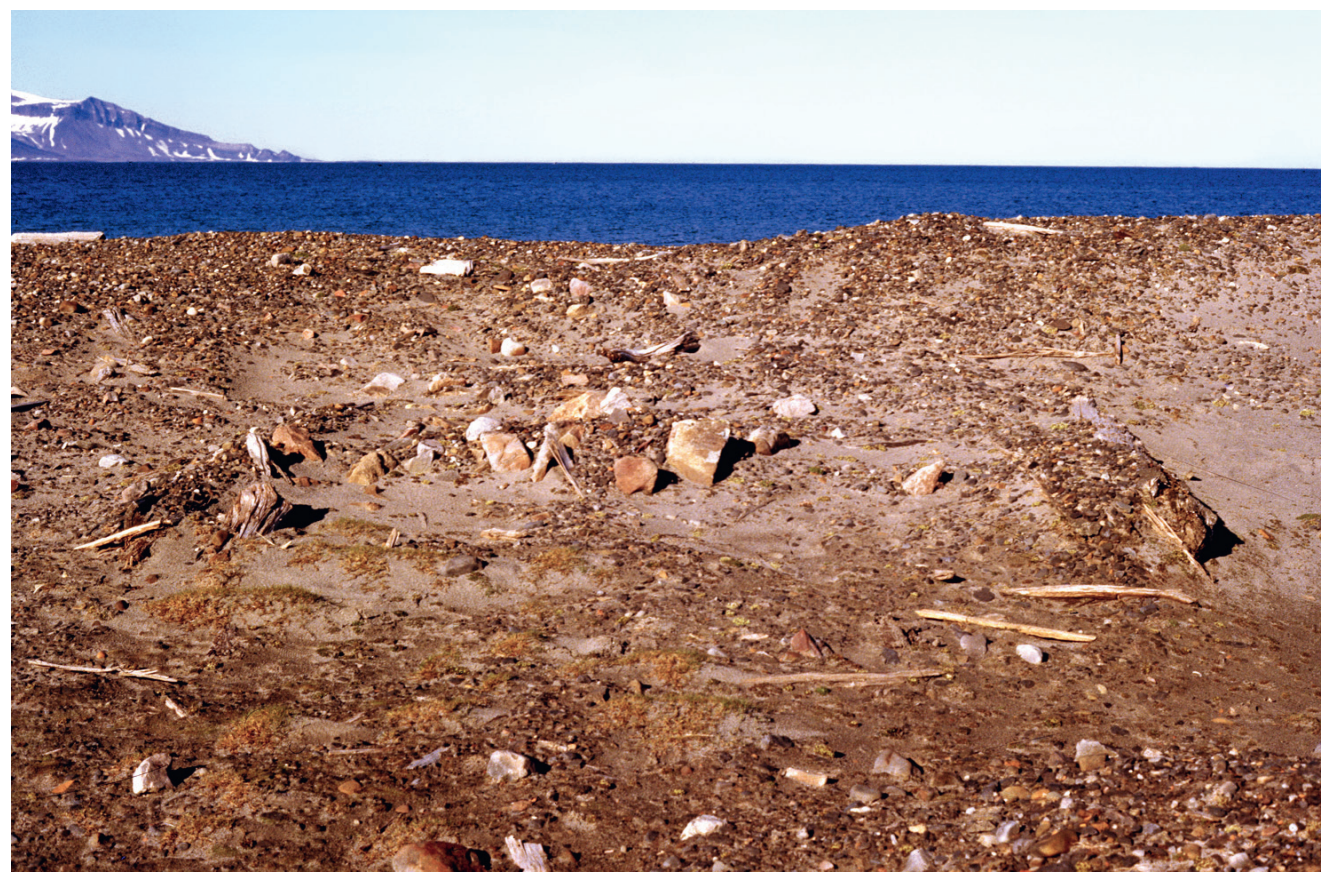

Fig. 3. Remains of a building with stone stove/hearth (bath) at Mosvatnet 2

(“1639” - Chernykh 1987, pl. 2; Starkov 1998, pl. 3-4) ${ }^{10}$. Dates falling within the $17^{\text {th }}$ century were also obtained for the already mentioned site of Mosvatnet 2 ("1649" and "1673"), and for Sørkappvatnet ("1630”), both sites situated on Sørkappøya (Starkov 1990, pl. I) ${ }^{11}$.

Aside from Sørkappvatnet, all the mentioned sites lie very low above the sea level (Starkov 1998, pl. 4; Chochorowski 1999, figs 1, 3-4, 59-60). They were situated either behind (and below) the berm crest, in areas now surrounded by marshes or even flooded, or on beaches, within the reach of storm waves (Starkov, Korjakin, Zav'jalov 1983, 109-110; Starkov 1998, 49). The remains of the wooden buildings have survived in generally very poor shape. These typically were single, one-room cabins. Only in Mosvatnet were four buildings discovered (Fig. 3), but only two of them (a residential chamber and bath from Mosvatnet 2) were probably used contemporarily as elements of one, functionally connected complex (Zav'jalov, Starkov 1987, 242-245). Chronological positions of the remaining buildings, at a distance of $27 \mathrm{~m}$ (Mosvatnet 1) and $250 \mathrm{~m}$ (Mosvatnet 3) from Mosvatnet 2, are difficult to establish (Zav'jalov, Starkov 1987, 242) ${ }^{12}$. The ruins of a cabin at Sørneset (Aurodden), about $10 \mathrm{~m}^{2}$ in area, lie on a very low (lower than the current berm crest) old terrace, in the forks of a small creek (Fig. 4), approximately $100 \mathrm{~m}$ from today's shoreline (Chochorowski 2002, figs 11 and 15) ${ }^{13}$. Situated

${ }^{10}$ This date does not appear in Starkov 1990, pl. I.

${ }^{11}$ In Starkov 1998, pl. 4, the site of Mosvatnet is dated to "1648", and the date for Sørkappvatnet has not been given at all. In the lists published by N. B. Chernykh (1987, pl. 2 and 1990, 117) Mosvatnet 2 is marked as " 1648 ", and no information is provided regarding the younger date for Sørkappvatnet.

${ }^{12}$ Within the building designated as Mosvatnet 1 there are remains of a stone kiln-hearth typical of a steam bath; perhaps the structure was not a residential one.

${ }^{13}$ As during a visit by J. Chochorowski and M. E. Jasiński in 1990. 


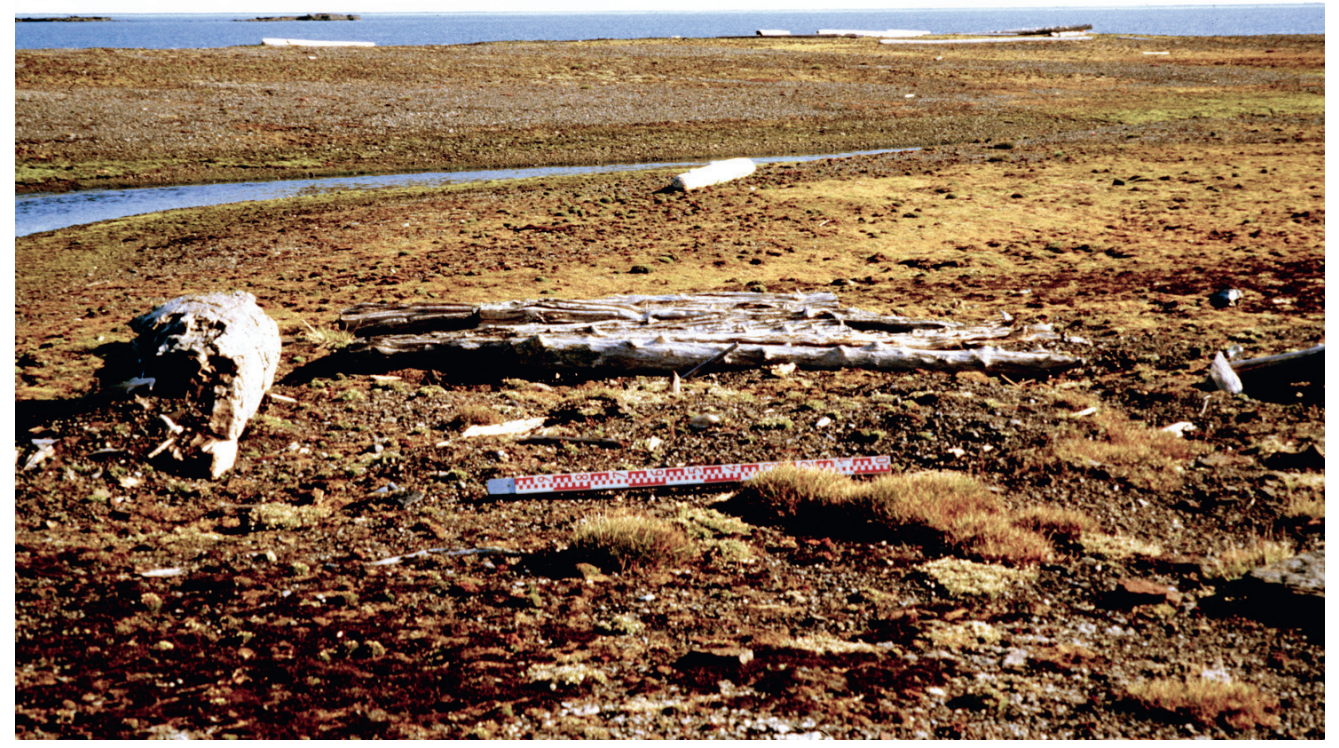

Fig. 4. Remains of a cabin in Aurodden (Sørneset), situated more than $100 \mathrm{~m}$ from today's shoreline, in the place now flooded by surface waters

on a rocky headland (Sørkapp), on a high (6-8 m) terrace, the site of Sørkappvatnet (Fig. 5) represents a more complex layout. It is comprised of the ruins of a cabin (most likely with a small entrance hall), remains of five monumental crosses, and at least eight graves (Chochorowski, Jasinski 1993, fig. 2; Chochorowski 1999, photo 2). The small cabin, about $8 \mathrm{~m}^{2}$ in floor surface, was built of driftwood. According to the explorers of the site (Zav'jalov, Starkov 1987, 245-246), it may have been erected in place of an older building. Apart from the mentioned dendrochronological dates of " 1556 " and "1630", the cabin has been historically dated to 1784 and 1794 (Conway 1906, 259 and 268; Chochorowski 1999, 15, footnote 3). A complex of a similar nature and sharing a similarly high location ${ }^{14}$ is known from Skolteneset, the northern promontory of Sørkappøya (Chochorowski 1999, photos 11-12). It comprises of ruins of a large cabin (about $40 \mathrm{~m}^{2}$ in floor surface) and the shaft of a monumental cross (Figs 6 and 7), beneath which a deposit of nine human skulls has been found, possibly a secondary burial. The one-room cabin was built from regular timbers, perhaps kind of "prefabricates" brought from the continent ${ }^{15}$. Apart from a dendro date of " 1761 " acquired for the shaft of the monumental $\operatorname{cross}^{16}$ (36 $\mathrm{cm}$ in diameter), the site also yielded a bone comb with an inscription reading "in the year of 1837" (Zav'jalov, Starkov 1987, 247). What we know about the wintering of

\footnotetext{
${ }^{14}$ Six metre terrace, today undercut by a 2 metre high cliff.

${ }^{15}$ This was a widespread solution among the Pomors (Starkov 1998, 48), an important element of their hunting strategy oriented on the maximization (within the short polar summer season) of spoils, in particular walrus tusks valued in jewellery (Tegengren 1962, 312-337).

${ }^{16}$ Which in the opinion of the site's explorers (Zav'jalov, Starkov 1987, 247) means the Skolteneset cabin was built: "no later than the second half of the $18^{\text {th }}$ century".
} 


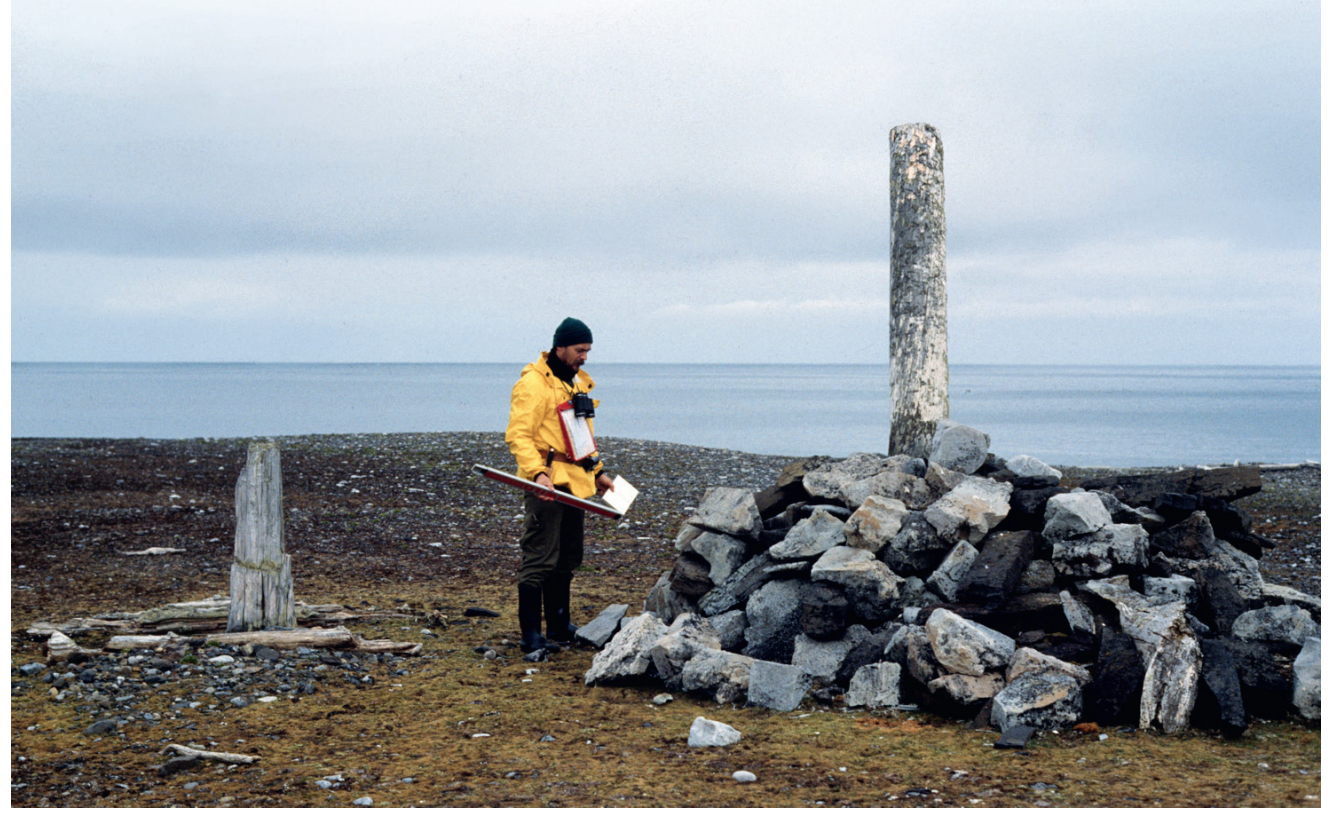

Fig. 5. Remains of the monumental cross (left) and later navigational mark at Sørkappvatnet (Sørkapp)

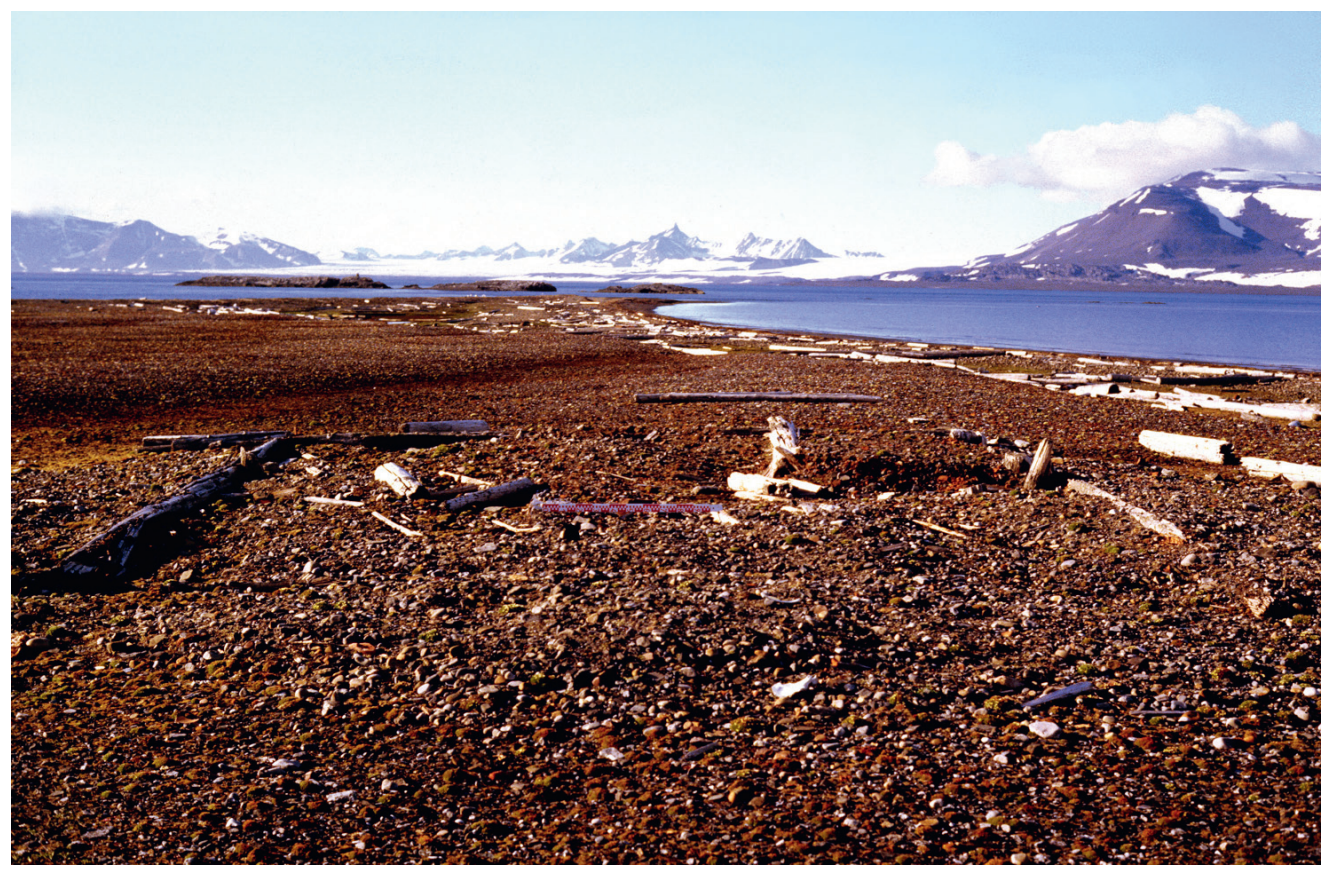

Fig. 6. Remains of the cabin at Skolteneset (Sørkappøya) built from carefully hewn 'prefabricates' 


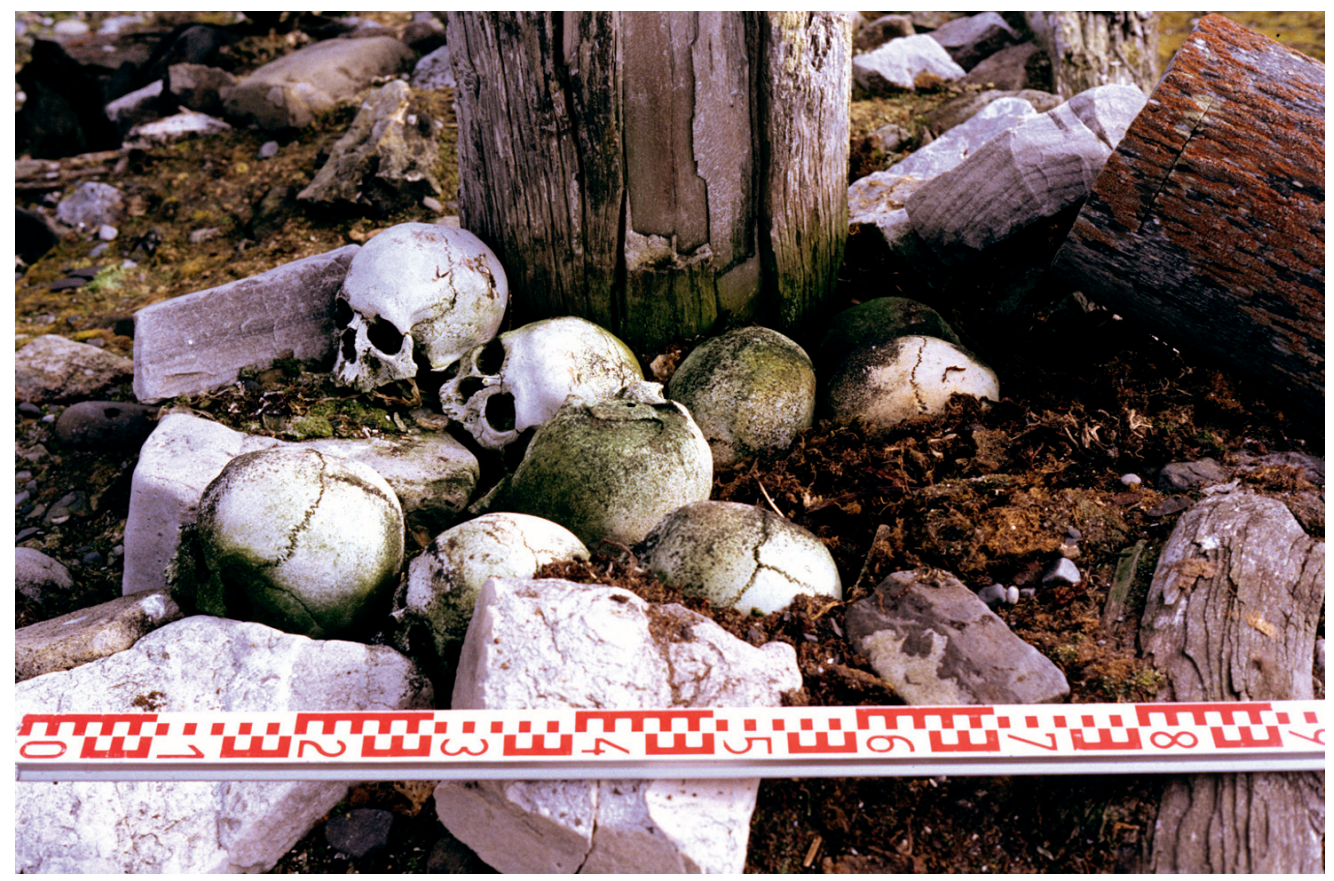

Fig. 7. Remains of the monumental cross with deposit of skulls (secondary burial) near the Skolteneset cabin

a group (artel) of 18 Russians in South Cape (i.e. Sørkappøya) in 1837, when all the hunters died, should most likely also be linked to the Skolteneset station (Conway 1906, 274). It should be noted that all the Pomor stations in this region ${ }^{17}$, both on Sørkappøya and Sørneset, were situated in places difficult to navigate due to skerries and shoals. On the other hand, these were places where walrus colonies were abundant, as reflected by the historically attested efficiency of walrus hunting in the region (Conway 1906, 259-260) and by the huge amount of bone remains which can be found there even today (e.g. on Stjernøya).

\section{Architecture and structure of hunting stations in northern Sørkappland}

Interesting information on the differentiation of Pomor stations in the analysed region can be derived from analysis of the timber from which they were built. For instance, the Pomor cabin on Bjørnbeinflyene (Fig. 8), known from Polish excavations (Chochorowski 1989a, 208-246), was made from materials of very diverse origin. First, massive round timbers, probably driftwood, were set from the northern and southern sides (Fig. 9). It was only on these that carefully worked timbers (obviously prefabricates) were fixed as sill beams for the western and eastern

\footnotetext{
${ }^{17}$ It remains unclear whether there was any connection (and if so, of what nature) between the stations from that region and a large Pomor station (five cabins, shaft of a monumental cross, and a mooring post) in Bettybukta, an easily navigable bay on the Sørkappland's eastern coast (known to the authors from personal information from its discoverer, Professor W. Ziaja from the Jagiellonian University (cf. also Ziaja 1993, 121-123, 1995, figs 2-5).
} 


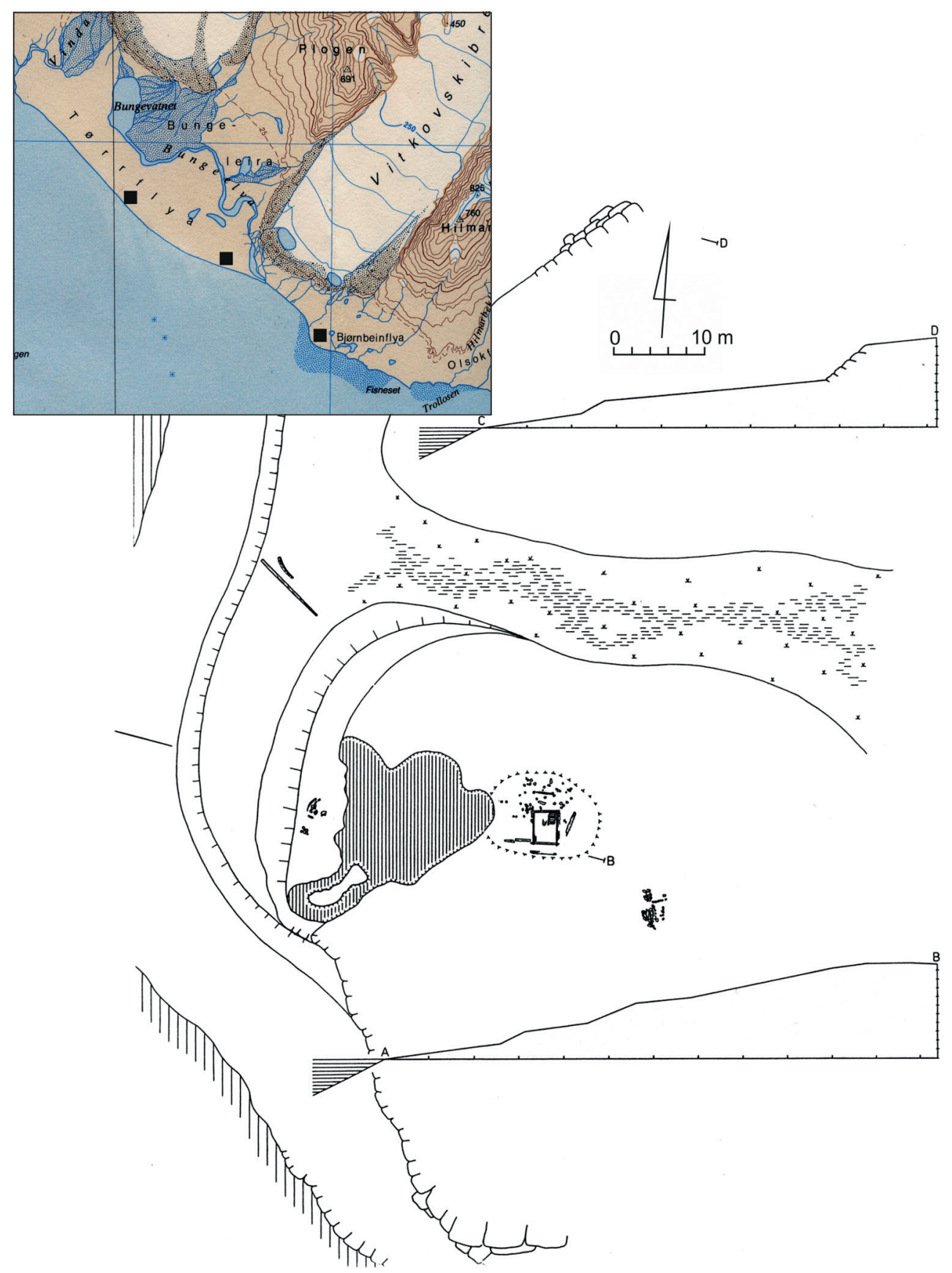

Fig. 8. Location and arrangement of features in the Bjørnbeinflyene site situated near the remains of a landing place on the Tørrflya coast 

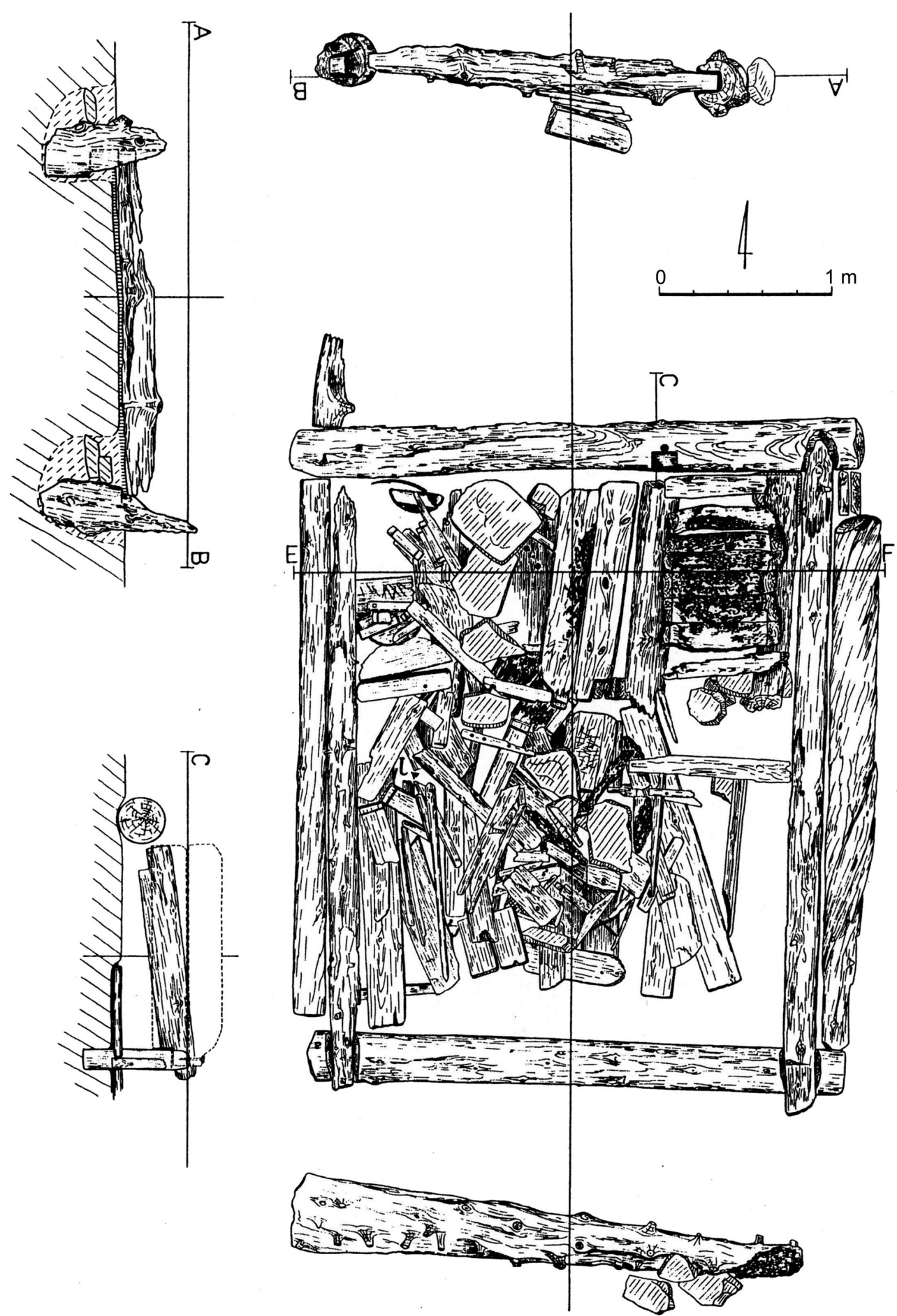

Fig. 9. Sill beams and ruined interior of the cabin at Bjørnbeinflyene built from hewn 'prefabricates' and drift-wood 


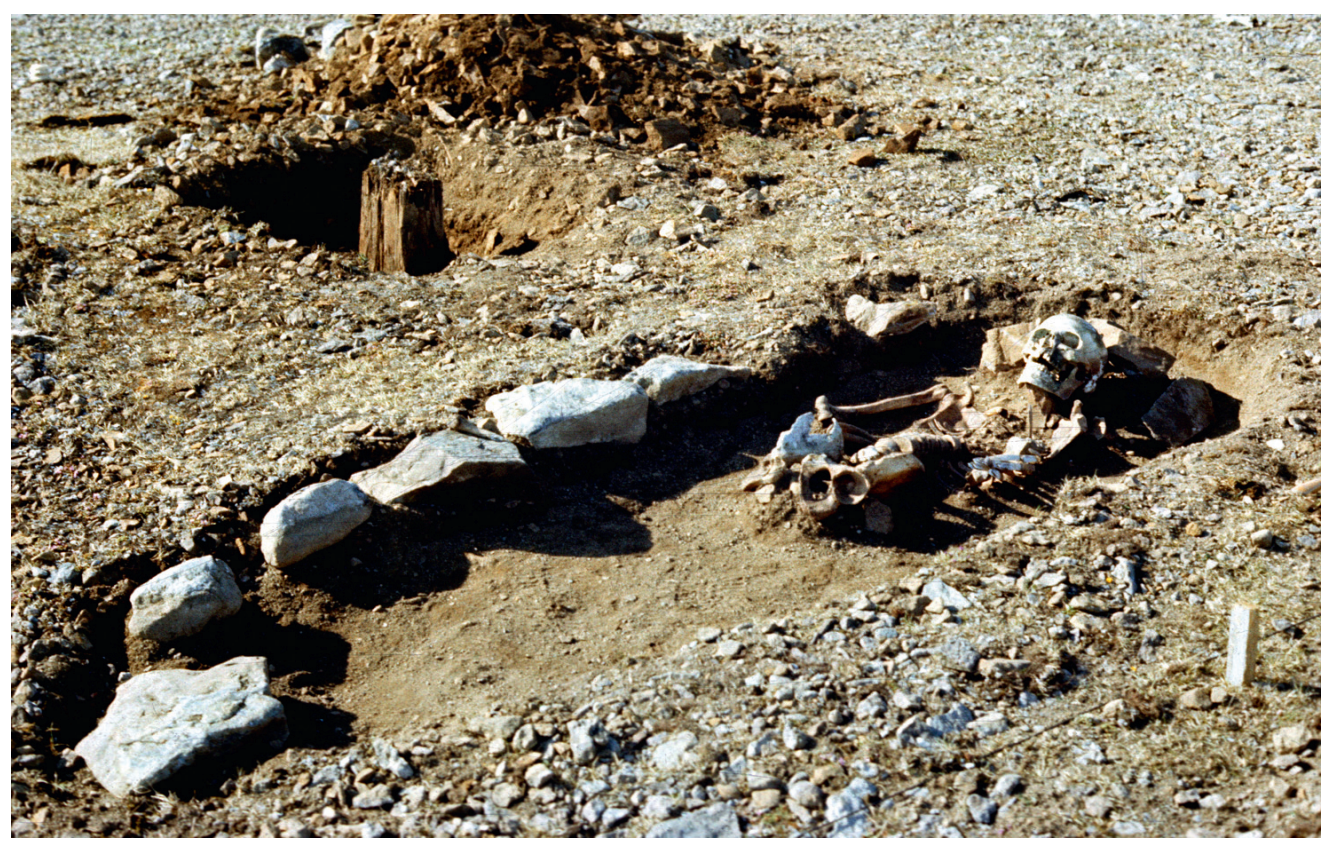

Fig. 10. Remains of the monumental cross and a burial damaged by animals in the vicinity of the Bjørnbeinflyene cabin

walls. To seal and stabilise the construction, the walls were additionally lined with more robust, round, drift wood timbers, partly dug into the ground. As well, wood from a damaged or dismantled ship ${ }^{18}$ was re-used in the cabin's construction: the central part of the floor was made from planks bearing the remains of characteristic pegs which originally attached the deck to the hull frame. The room, $8.3 \mathrm{~m}^{2}$ in floor surface, had a brick stove/hearth in a corner. An outhouse (entrance hall of a kind) was added from the north, whose longer wall was also built from driftwood in the timber-frame construction. Remains of a monumental cross were discovered near the cabin, with the shaft made from a hewn beam (Fig. 10). The nature of cultural remains (e.g. the size and thickness of the rubbish layer) is indicative of quite long, or intensive, exploitation of the site. The discovery of a kaolin tobacco pipe (Fig. 11) allowed this site to be approximately dated to $1770-1810$, with the focus on the late $18^{\text {th }}$ century (Chochorowski 1988, 128-129).

The cabin on Bjørnbeinflyene was built on a high (11 $\mathrm{m}$ a.s.1.) promontory hardly accessible from the sea due to numerous skerries. The approach was much easier in the north-western section of the Tørrflya coast, beyond the mouth of the Bungeelva (Fig. 8), where the traces of a landing-place were discovered, in the form of the remains of three mooring posts fixed into the ground and reinforced with small piles of stones (Chochorowski 1988, 131-132, fig. 8; 1989a, 248-251; Chochorowski, Jasinski 1988, 52-54). Another mooring post was identified in the middle part of the Tørrflya coast, near which structural elements (frames, clamps, deck planks, hull planks) from a damaged boat (Figs 12 and 13) or possibly small ship were found.

\footnotetext{
${ }^{18}$ According to V. F. Starkov $(1998,48)$, the Pomors acquired such wood dismantling old ships in Spitsbergen.
} 
It cannot be ruled out that these were the exact landing places used by Pomor sailors and hunters operating in this part of the coast.

The relics of the Pomor station on Palffyodden on the southern side of the Hornsund mouth are more complex (Fig. 14). They are situated in a place hardly accessible from the sea (Chochorowski 1988, 125-127), and consist of the ruins of three cabins (Fig. 15), of which one (A) was built on an old berm crest 6 metres high, while two $(B, C)$ on a lower, 3-metre high terrace (Chochorowski 1999, fig. 18). Nearby, a small cemetery consisting of five graves covered with stone pavements was found (Figs 16 and 17). The ground beams of cabin A, $17.4 \mathrm{~m}^{2}$ in floor

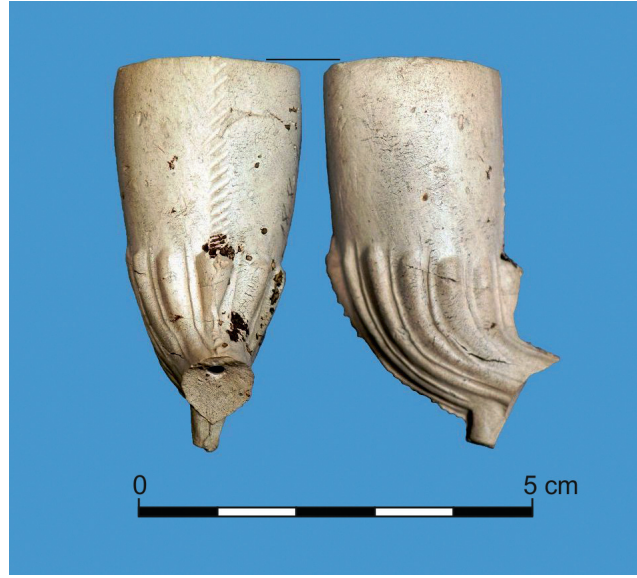

Fig. 11. Kaolinite pipe head found in the cabin ruins at Bjørnbeinflyene

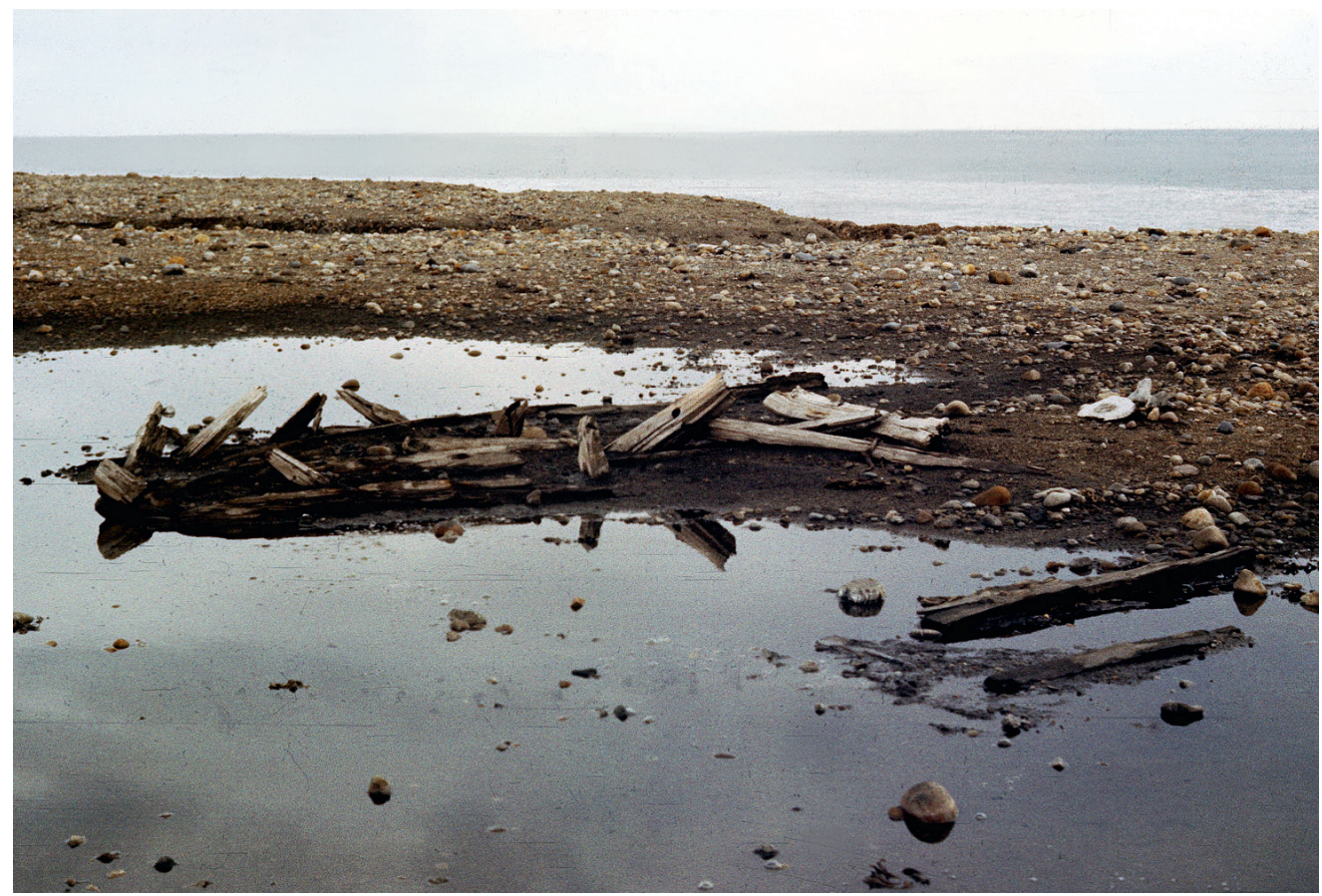

Fig. 12. Remains of a wrecked Pomor ship (lodja?) on the Tørrflya coast (landing place no. 1)

surface (Figs 18 and 19), were carefully worked, prefabricated beams, not particularly thick (Fig. 20). The floor in the cabin's centre was made from planks undoubtedly originating from a shipwreck. Analogically to the Bjørnbeinflyene cabin, a brick stove/hearth was situated next to the entrance, on a wooden plinth flanked from the inside of the room by a post fixed in the 


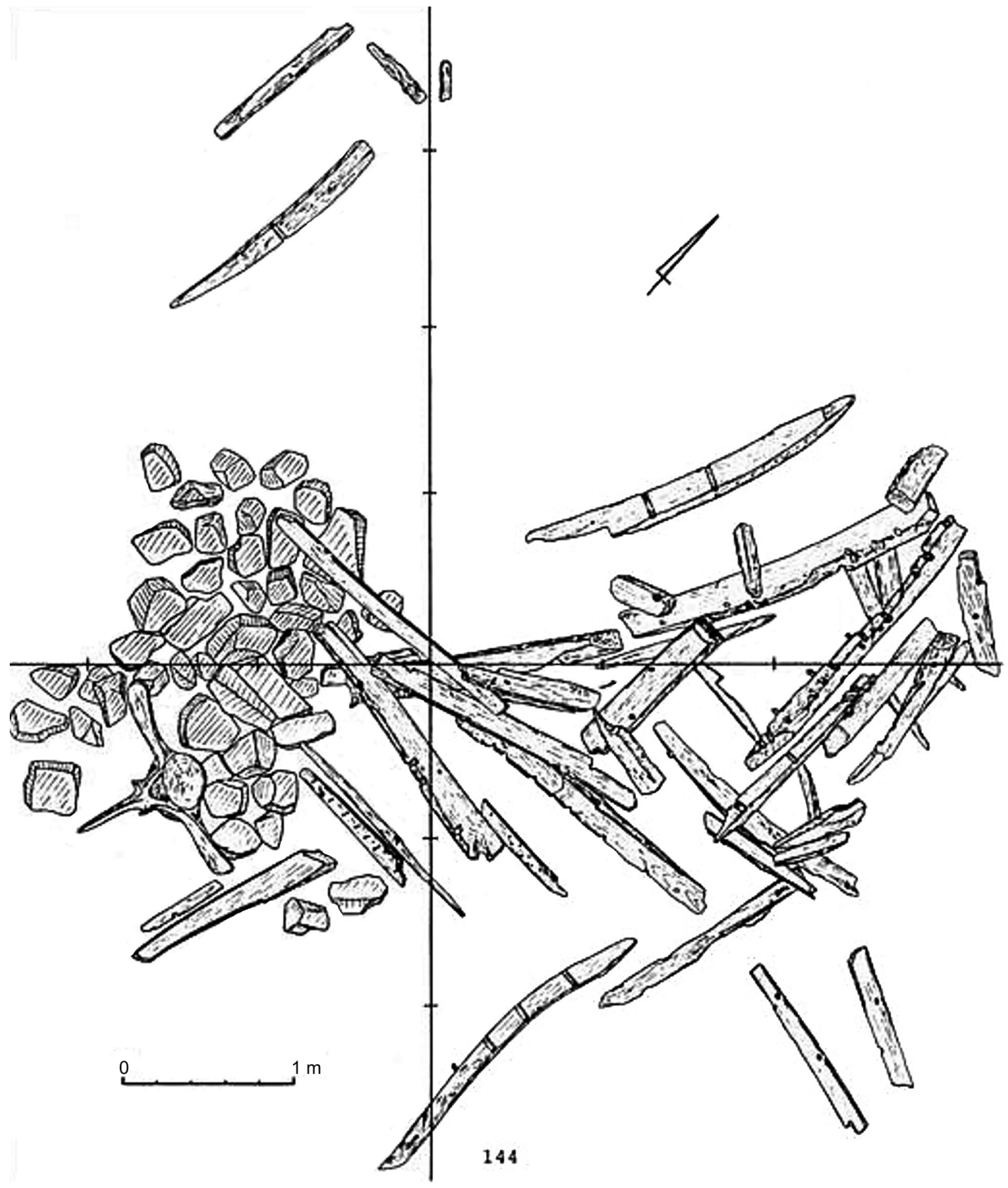

Fig. 13. Landing place with a whale vertebra as a mooring post, and structural elements of a shipwrecked 'lodja' in the Tørrflya 1 site

ground $^{19}$. A fragment of a kaolinite pipe stem found in the ruins suggests the cabin was used around 1720 (Chochorowski 1988, 126) ${ }^{20}$. Cabin B was situated in a place protected from the NW by a monadnock (Fig. 21), which means it was sheltered from vexing winds blowing from

\footnotetext{
${ }^{19}$ The floor, ground beams, as well as other, loose structural elements discovered in this cabin bear traces of a fire.

${ }^{20}$ In this context it seems interesting that semi-translucent muscovite plates were discovered in cabin A, which the Pomors used instead of window glass. It is possible that this is a feature typical of more archaic
} 


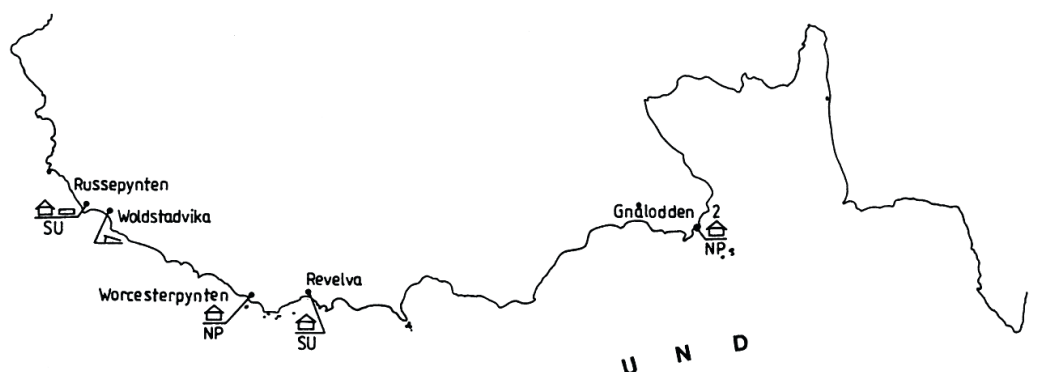

$A-\Delta$
$B-\square$
$C-\ddagger$
$D-\downarrow$
$E-D$

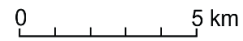
$5 \mathrm{~km}$

R

s

U N D 


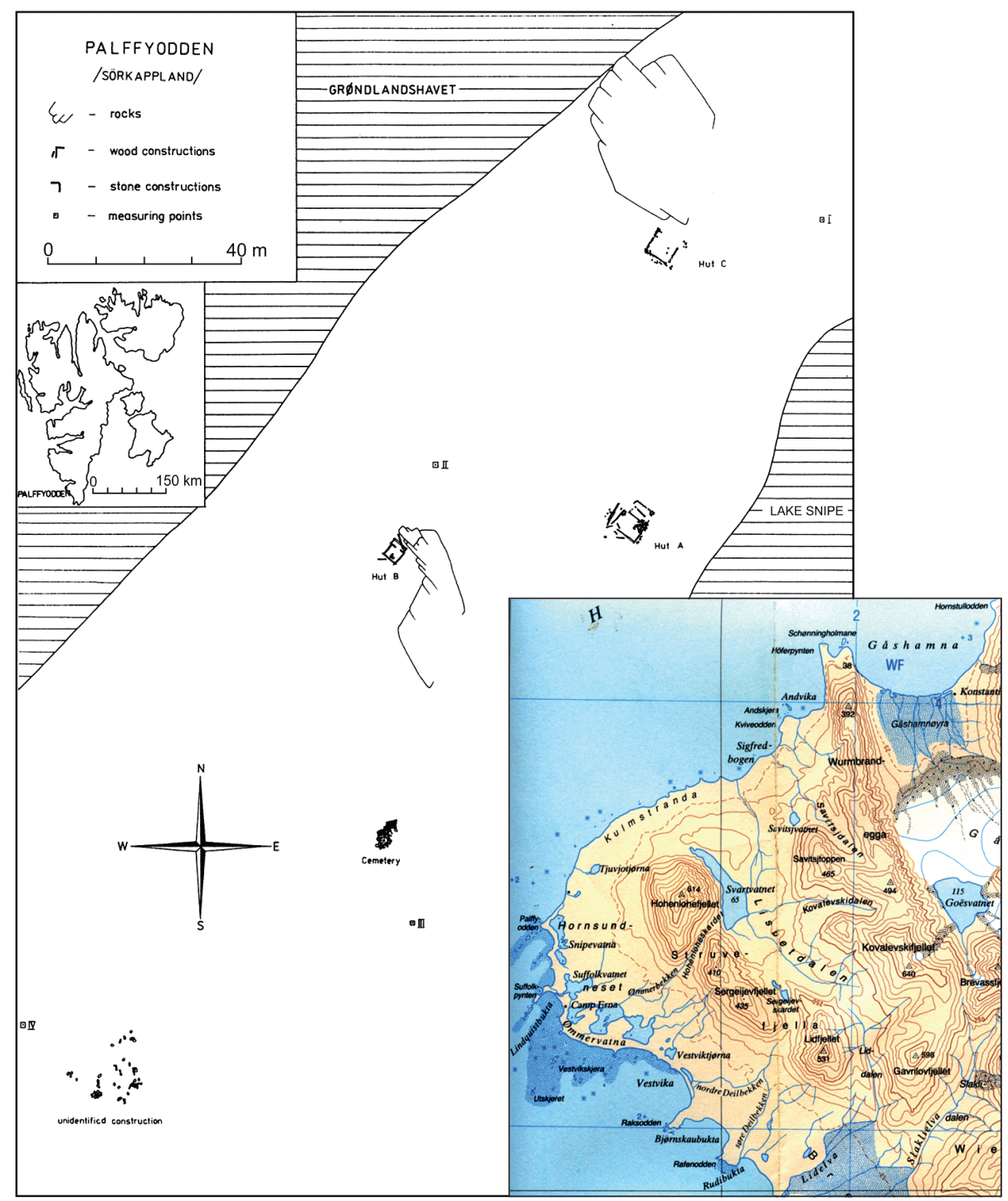

Fig. 15. Topography and arrangement of features in the Palffyodden site investigated by the expedition from the Jagiellonian University in 1982-1985

was added from the side of the monadnock (Fig. 22) ${ }^{21}$. The layout and constructional solutions make cabin B similar to the Bjørnbeinflyene hut. However, the material used (in particular its diversity) suggests it was a kind of makeshift construction, probably erected from the locally available drift material. Little can be said about the construction of cabin $\mathrm{C}$, also partly sheltered from the north by a monadnock (Fig. 15). All that survived is the cabin's outline (which

${ }^{21}$ This is not the most typical variant of the solution, as one of the ends of the horizontal beam had a semicircular indentation made in order to fix it between the corner posts (Fig. 22). 


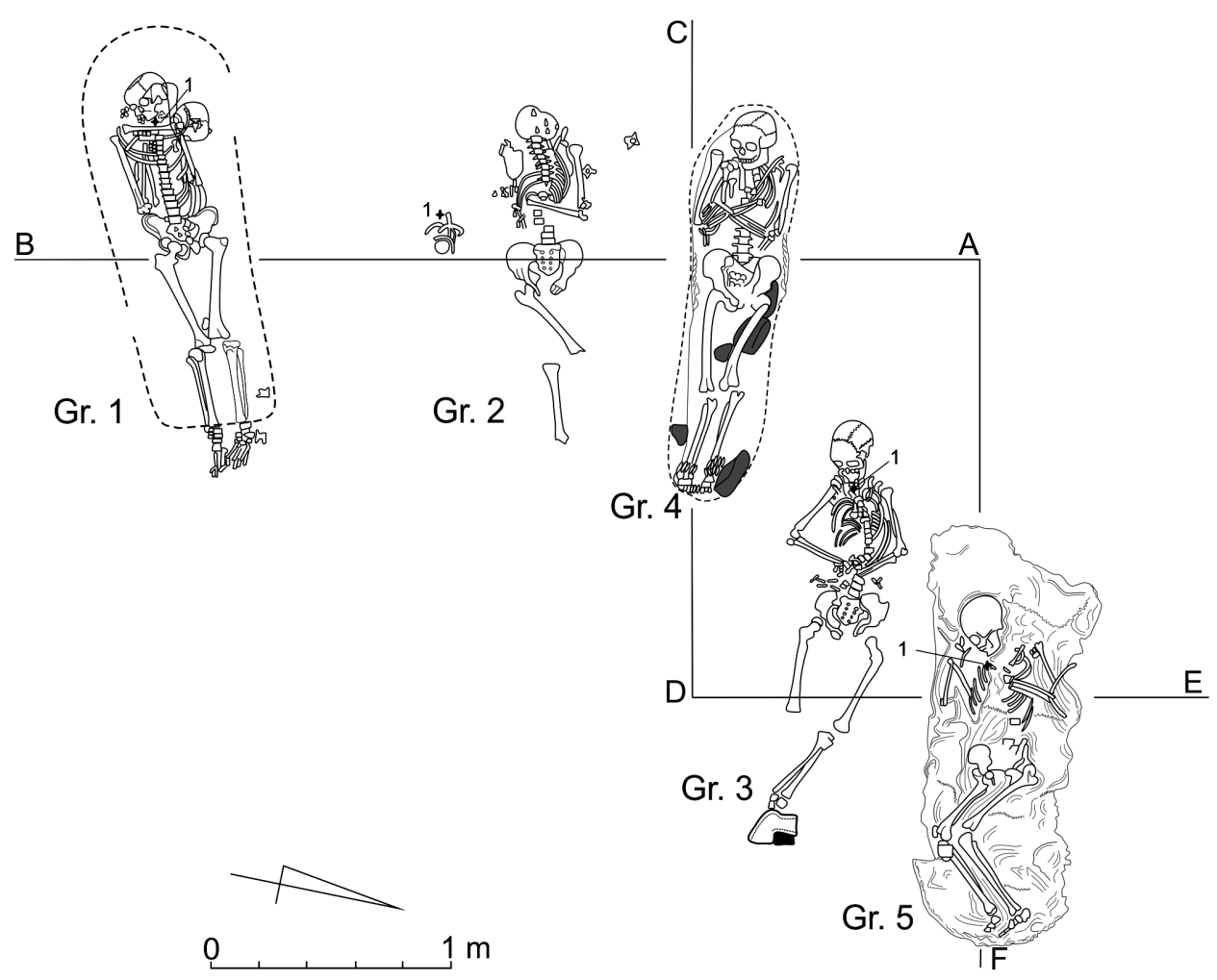

Fig. 16. Distribution of burials within the cemetery at Palffyodden

allowed the floor surface to be determined as about $15 \mathrm{~m}^{2}$ ), the remains of stones originally facing the ground beams, and fragments of bricks from the stove/hearth. The finds of kaolinite pipe fragments date the time when the structure was used to around mid-18 ${ }^{\text {th }}$ century $(1750-1760)$ (Chochorowski 1988, 127). The thickness of cultural deposits indicates that cabin $\mathrm{C}$ was used for the longest time. In general, everything indicates that the cabins in Palffyodden were not built at the same time. They most likely were built in succession, perhaps because a certain tradition developed of returning to places which were convenient from the point of view of hunting strategies ${ }^{22}$.

\section{Architecture and structure of hunting stations in the Hornsund fiord}

The Pomor station in Schönningholmane, on the southern side of Hornsund, has an equally complex structure (Fig. 23). It is also comprised of three buildings, of which two (cabins B and $\mathrm{C}$ ) were built close to each other, vis-à-vis a rocky promontory, while the third one (cabin A) approximately 80 metres further to the west, vis-à-vis a narrow canal leading between the rocks to a sandy beach (Chochorowski 1989, fig. 9). Cabins B and C (Fig. 24), investigated

\footnotetext{
${ }^{22}$ This could be due to its strategical location within the region (including the southern Hornsund coast), and to numerous skerries and shoals being natural walrus habitats.
} 


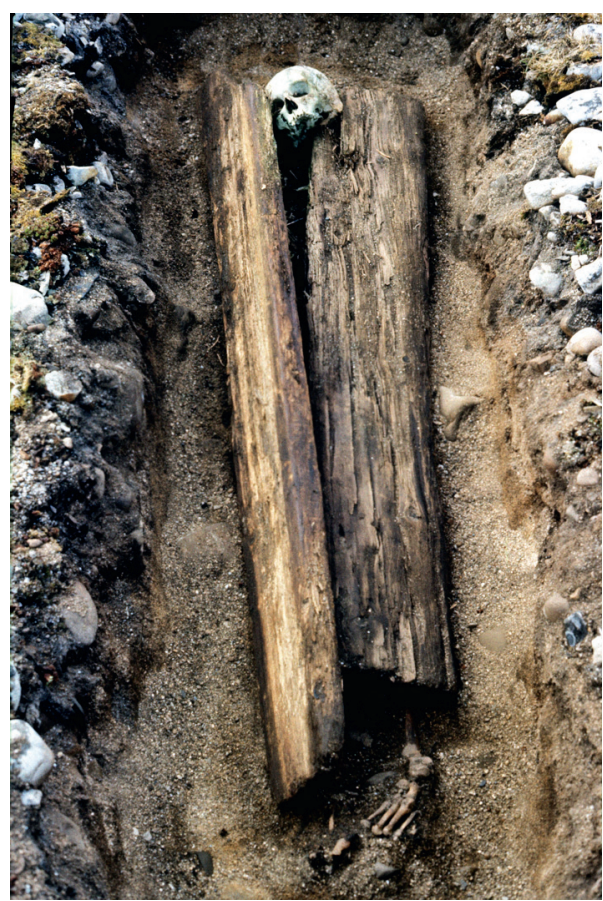

Fig. 17. Burial boarded with planks in grave 1 at Palffyodden

in detail during the Polish excavations of 1987 (Chochorowski 1988, 129-131), were erected from carefully prepared beams (prefabricates) fitted to each other in a typically Pomor manner ( $v$ oblo $s$ ostatkom $)^{23}$ and sealed with moss. Even in the floors no secondarily used elements were recorded. Cabin B (Fig. 25) stands out with its dimensions ( $31 \mathrm{~m}^{2}$ in floor surface), and was surely intended as a base for a large group of hunters (known in Russian as artel). However, it was used relatively briefly, and traces of burning on some of the structural elements may even suggest that this hunting party, and/ or the building itself, met with a violent end. The nearby cabin $\mathrm{C}\left(14 \mathrm{~m}^{2}\right.$ in floor surface; it touches cabin B with its corner) was provided with a stone stove (Fig. 26), which means it originally played the role of a bath (bania). It was only later that a smaller room was added to it (built on the already formed cultural layer) and the function was probably changed to a dwelling. In addition, it is possible that the small room was built from the remains of cabin $\mathrm{B}$, since its surviving structural elements also bear traces of burning ${ }^{24}$. The rich inventory recovered from the layer of destruction and the

floor of cabin C leaves no doubt that the building was used as a dwelling and, most likely, was not fully evacuated. Aside from firearms, the recovered artefacts comprised nearly a full set of hunting and personal equipment (e.g. a bag with lumps of sulphur and flints for a flint-lock rifle, a lump of lead for casting rifle balls, a beautifully adorned snuff-box made from birch bark, a fur glove, and a wool cap), as well as pieces of broken furniture. Pieces of window glass and fragments of wax votive candles, lying on the floor by the south-west wall, deserve particular attention. They probably mark the place where there originally was a window, perhaps with an icon above it. On a small hill near cabin B a shaft of a monumental cross was uncovered, set deep in the ground, next to which there was a grave, marked on the surface with a setting of stones and bricks.

The test excavations of cabin A (carefully built, floor surface of $22 \mathrm{~m}^{2}$ - Fig. 27) carried out by a Norwegian-Polish expedition in 1989 (Chochorowski, Jasinski 1993a, 23-33) revealed that the building was identical with cabins $\mathrm{B}$ and $\mathrm{C}$ in terms of both the material used and the technique of construction. The cabin's corner closest to the brick stove/hearth bears traces of

\footnotetext{
${ }^{23}$ A technique typical of the Pomor architecture, in which each horizontal beam has a semi-circular groove made along the whole length of its bottom side, which fits the natural, upper edge of the beam below (e.g. Starkov 1987, 246-247). Apart from making a building highly impermeable, such a solution prevents rain water from soaking between the beams.

${ }^{24}$ However, the stove/hearth was interestingly not rebuilt into a brick one, typical of dwellings; perhaps the cabin's user or users acted under the pressure of time.
} 


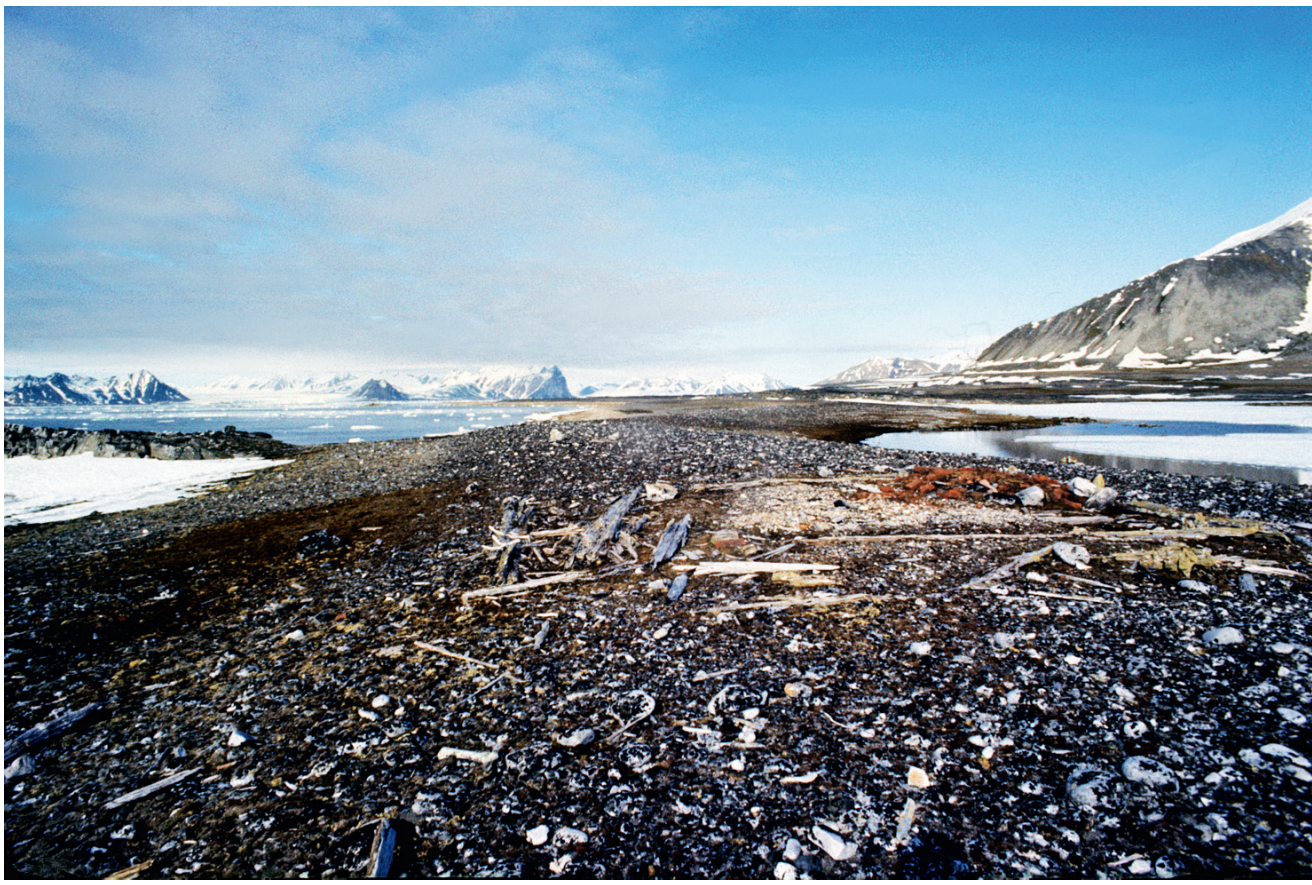

Fig. 18. Palffyodden, cabin A; state of preservation at the ground surface level, prior to the excavations

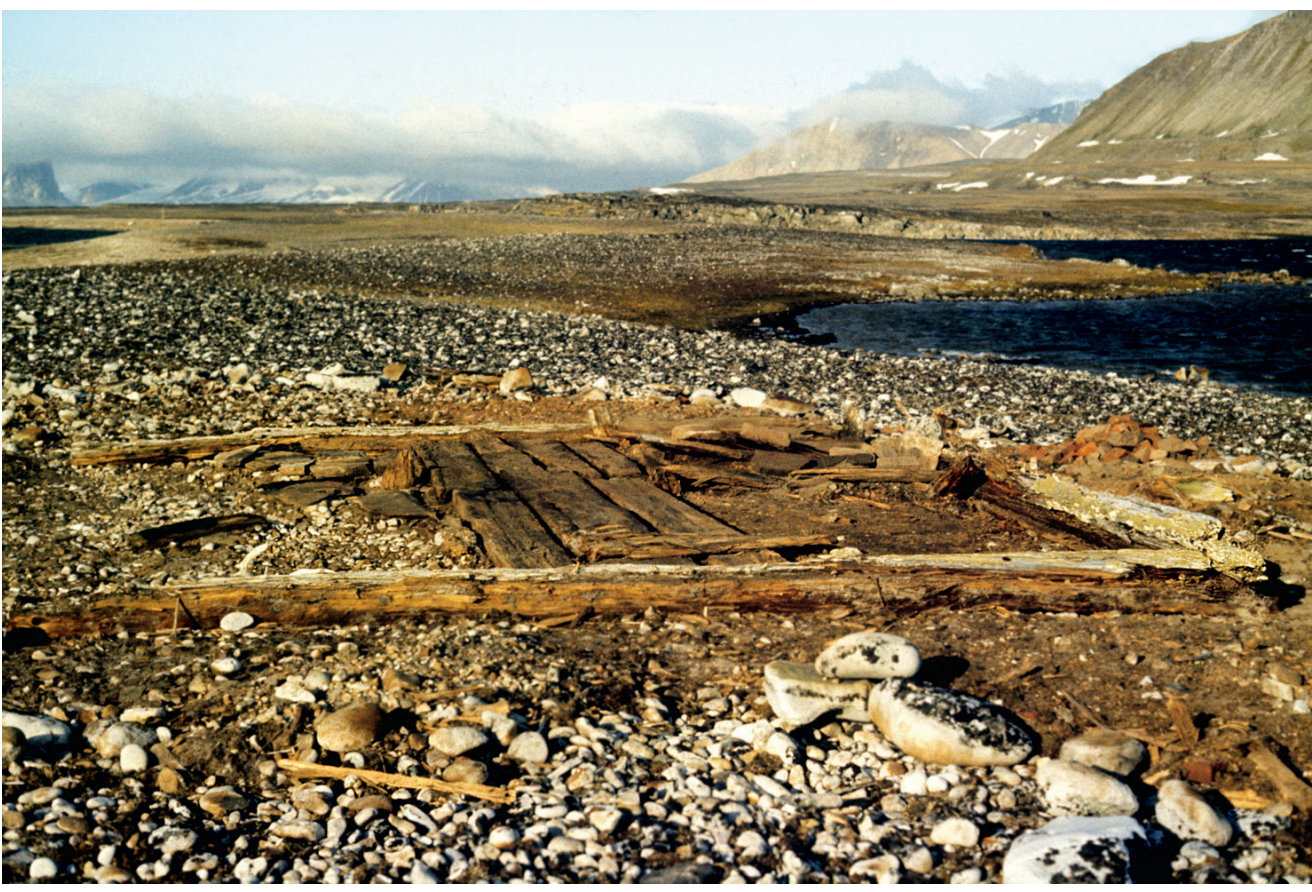

Fig. 19. Palffyodden, cabin A; sill beams, floor, and ruins of the stove - view after cleaning 


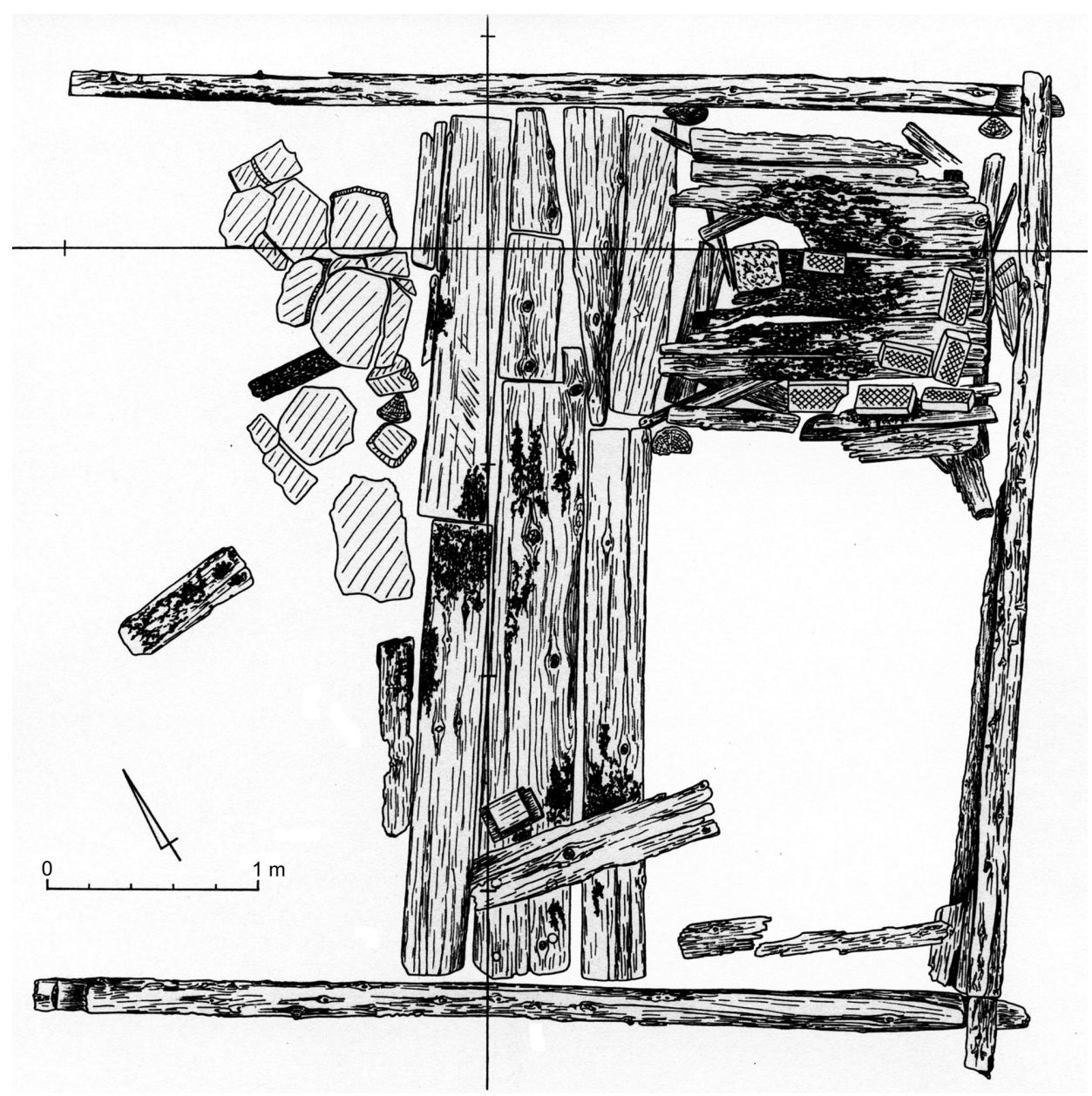

Fig. 20. Palffyodden, cabin A; Remains of the building - the foundation of the stove, floor planks, and sill beams bear traces indicative of the exposition to fire

burning, but other parts of the ground level and the damaged pieces of furniture, discovered both on the wooden floor and earthen floor, did not show traces indicative of a fire. In front of the entrance to cabin A, an atypical feature was uncovered: the relics of a stone stove/hearth, functioning in the open air though possibly roofed or sheltered by some structure supported by three posts. This supports the view about a unique role of cabin A. It was no doubt a dwelling, but its chronological relationship to cabins $\mathrm{B}$ and $\mathrm{C}$ cannot be archaeologically determined. Nevertheless, its location opposite the landing place, and the presence of additional features, suggest that cabin A could have been the house of the skipper (kormshchik) who directed the entire hunting enterprise. The characteristics of the construction material used indicates that all the three buildings were erected within the same episode and originally formed a functionallyrelated complex.

On a hill (37.6 $\mathrm{m}$ a.s.1.) dominating over the station ruins, and which offered a view of the entire surrounding area (the entrance to the fiord in particular), a shaft of another monumental 


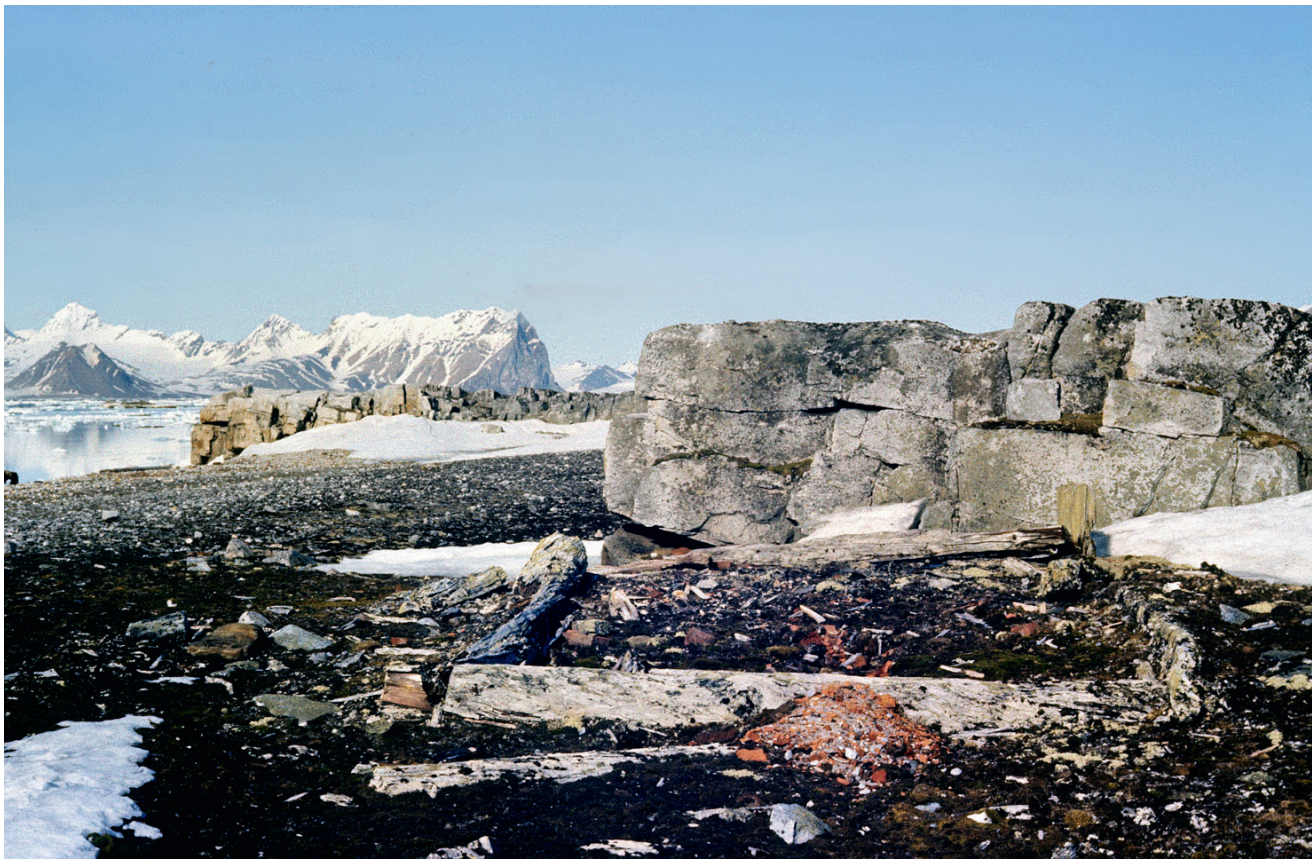

Fig. 21. Palffyodden, cabin B situated on a low terrace but above today's berm crest, in a place sheltered by a monadnock

cross was found, set in the ground and reinforced with a stone mound (Figs 28 and 29). The cross had been most likely deliberately cut down ${ }^{25}$, and its arms were found in a deep ravine, approximately 80-90 m to the north-west of the shaft. Fortunately, the longer arm (nearly $2 \mathrm{~m}$ in length) was lying with its front side down, which prevented this part from complete decay, making it possible to partly decipher the letters cut into the arm's surface (Fig. 30). Admittedly, the inscription is not fully legible, but scribal abbreviations I? ИС and XC (Іисусь Христось) and a title $С \ldots$ БЖИ (Сынъ Божий) could be identified at the ends, flanking two lines of a prayer: КРЕСТУ ТВОЕМУ ПОКЛАНЯЕМСЯ В...? (the upper line), and - ...ТВОЕ ПОЕМЬ I? СЛАВИМЪ? (the lower line) ${ }^{26}$. Traces of some inscriptions (or more likely scribal abbreviations, perhaps the letter ' $M$ ") can also be seen on the cross's diagonal arm (podnozhe), but these are virtually illegible. It is also telling that the lower termination of the cross's shaft, fixed into the ground, was carefully modelled into a shape resembling a dome of an Orthodox church, only turned upside down (Fig. 29). It seems beyond any doubt that this is a re-used detail from some other structure ${ }^{27}$. The cross itself was most likely erected after the artel of hunters had landed and the decision to found the station (or spend a winter) had been made, as a symbolical

\footnotetext{
${ }^{25}$ The same applies to two monumental crosses from the Sørkappvatnet site (Zav'jalov, Starkov 1987, 245), a cross from Sletneset at the mouth of Bellsund (Ovsjannikov, Starkov 1982, 78, fig. 7), or a cross from Diskobukta on Edgeøya (Chochorowski 2012, 675, fig. 13).

${ }^{26}$ The full text probably read as follows: "КРЕСТУ ТВОЕМУ ПОКЛАНЯЕМСЯ ВЛАДЫКО И СВЯТОЕ ВОСКРЕСЕНЇЕ ТВОЕ СЛАВИМ", which means "We bow before your Cross, O Lord, and we glorify your holy Resurrection" (see Chochorowski 2012, 673).

${ }^{27}$ Because it seems little likely that such a modelling would be applied for aesthetic purposes to the lower end of the cross's shaft, which remained invisible once the cross had been set into the ground.
} 


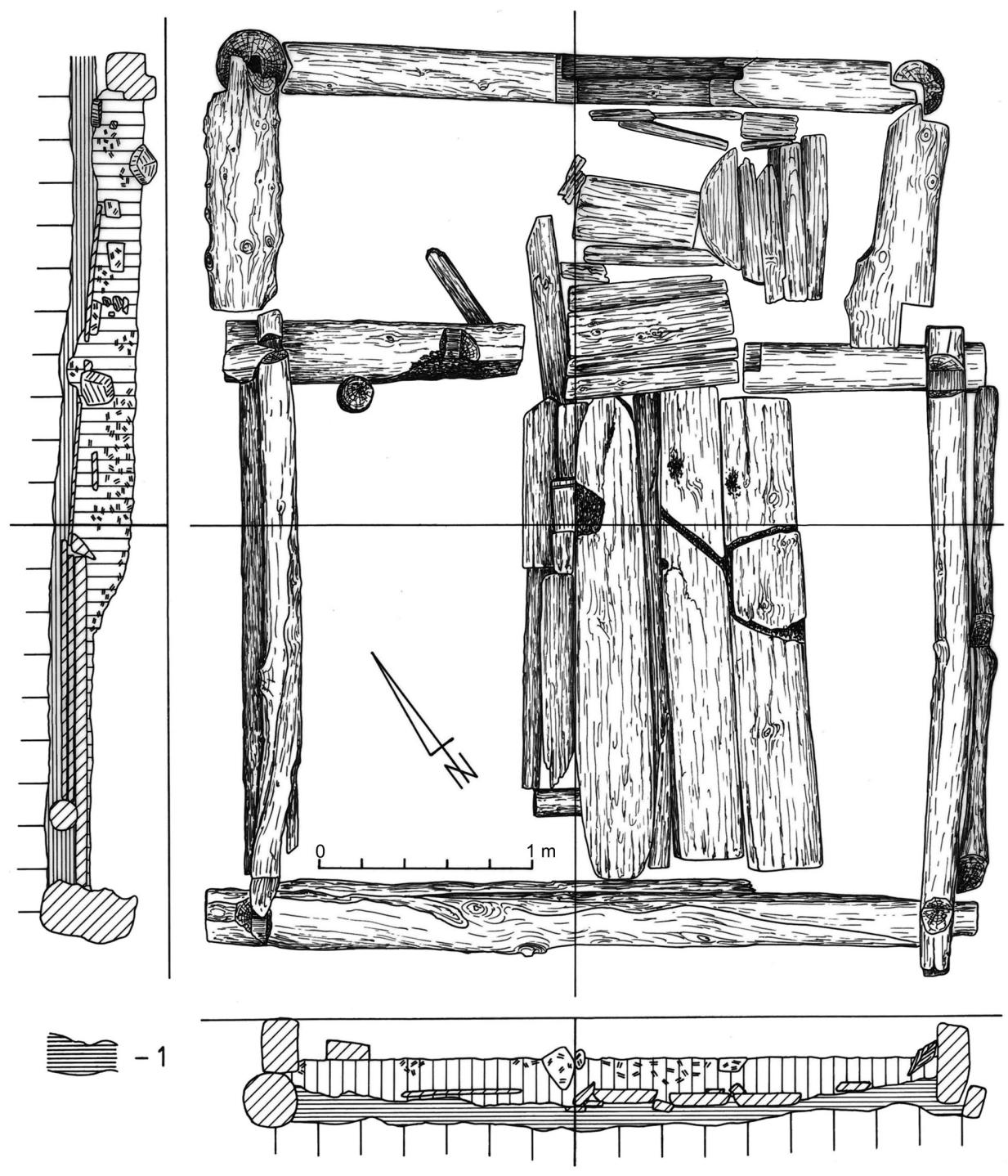

Fig. 22. Palffyodden, cabin B; Remains of the structure built from drift-wood - view after cleaning

sacralisation of the place and a votive offering for the success of the enterprise ${ }^{28}$. From the chronological perspective it no doubt marks the terminus post quem for building the station. There can be little doubt that the Schönningholmane station (unlike Palffyodden) was built in a single episode for the entire artel of hunters (cabin A - for the skipper, cabin B - for the rest of the crew, cabin $\mathrm{C}$ - as a bath), and served as a base (stanovaja izba) adapted to suit the needs

${ }^{28}$ The popularity of such sacra behaviours among the Pomor hunters is confirmed by numerous discoveries of relics of monumental Orthodox crosses in Svalbard, Nova Zemlja, or Bear Island (Keilhau 1831, 119; Bojarskij, Gusev et al. 1994, 23, 36-37; Filin, Frizin 2001, 166-198). 


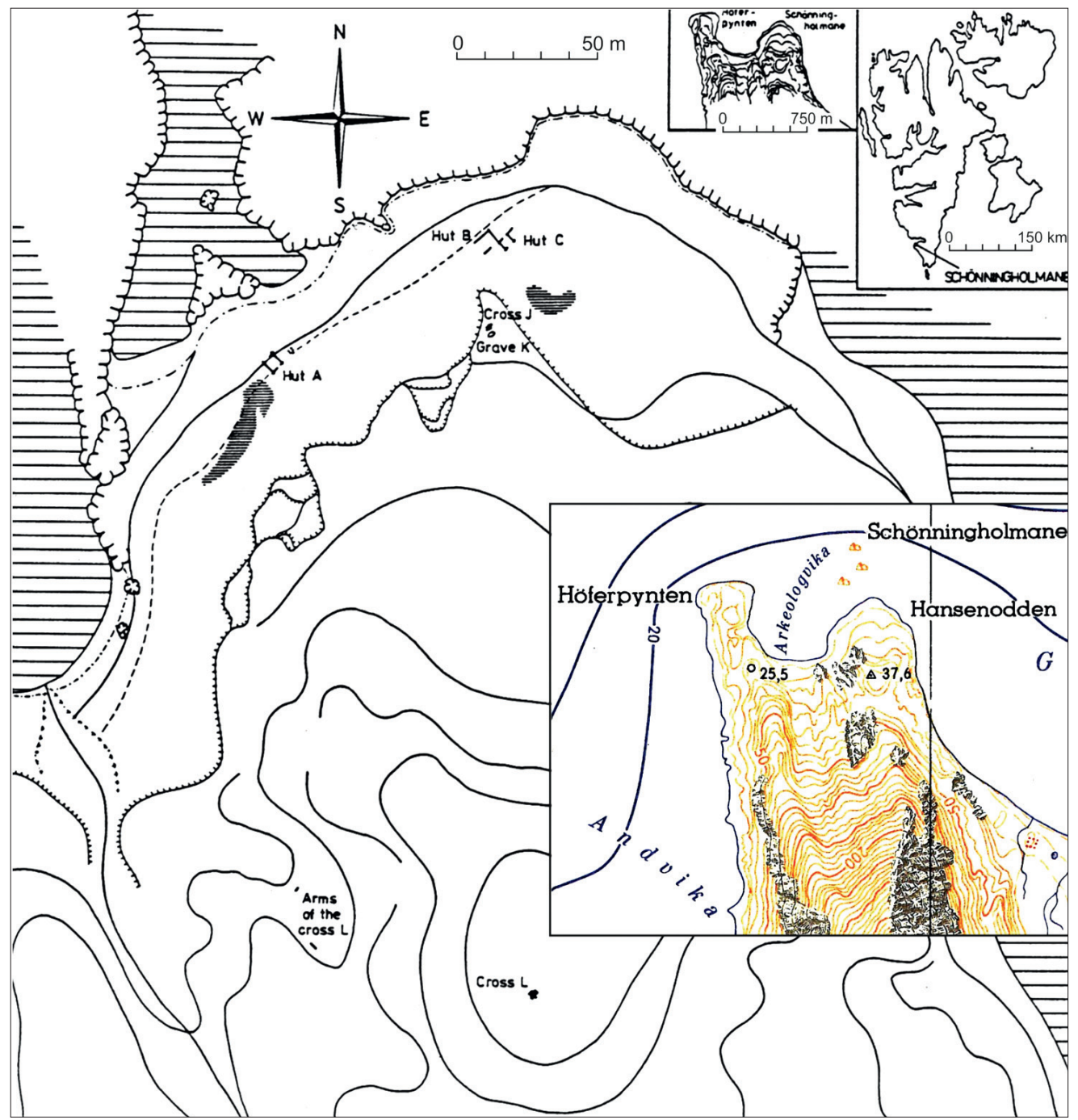

Fig. 23. Topography and arrangement of features within the Pomor station at Schönningholmane

of winter stay. A nearby bay ${ }^{29}$, very small but deep, well protected from the sea waves by the Höferpynten promontory and sheltered from the winds blowing from the fiord by the rocks of Schönningholmane, was a perfect anchorage for a small ship in the kind of grumantskoj koch typical of the Pomors (Starkov, Chernosvitov 1990, 168-181; Starkov 2012, 227-232). Only after the station had been abandoned (or burnt down in a fire), its best-preserved building (bath) was adapted as a dwelling, but this time for a small group or even a single hunter ${ }^{30}$.

\footnotetext{
${ }^{29}$ On the map published by the Institute of Geophysics of the Polish Academy of Sciences, Warsaw 1987, sheet 5 - Hornsund, the bay bears the name "Arkeologvika".

${ }^{30}$ It cannot be ruled out that near the station on Schönningholmane (Hansenodden), in the western part of Gåshamny, there also are ruins of yet another complex of Pomor buildings (two houses or a two-room
} 


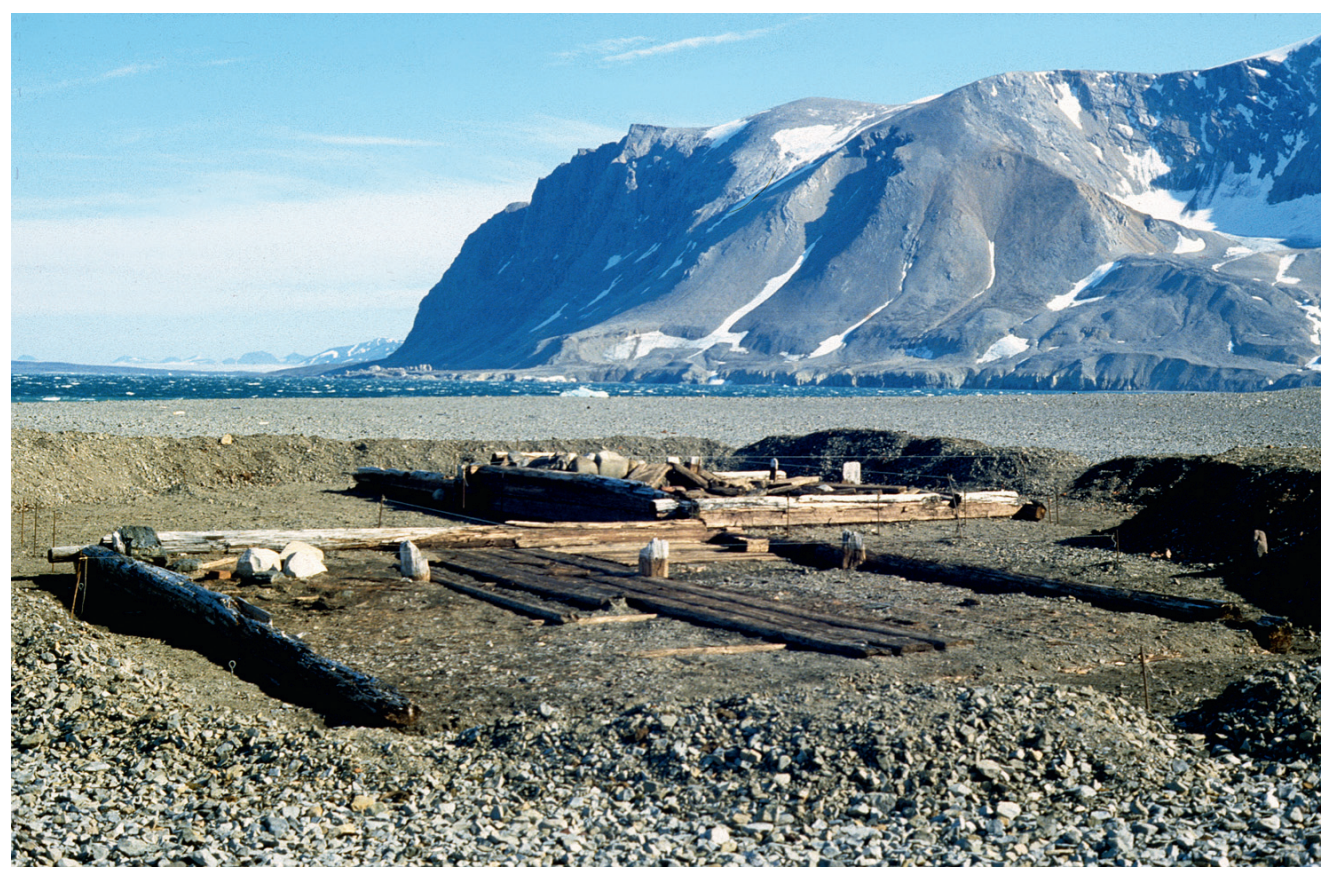

Fig. 24. Remains of cabins B (foreground) and C (background) at Schönningholmane - view after cleaning

Deeper into the fiord and on its northern shore, traces of the Pomor hunting activity are represented by a complex of two buildings on Gnålodden. They were built very close to each other behind a berm crest, on a small but navigable bay, at the feet of Gnålberget - an impressive precipice in the Sofiekammen range falling down to the fiord, the most distinct landmark of the Hornsund panorama ${ }^{31}$. One of the buildings (cabin A, $20.7 \mathrm{~m}^{2}$ in floor surface), explored by the Norwegian-Polish expedition in 1989 (Chochorowski, Jasinski 1993a, 1-23), represents a form slightly unusual for the region. It was erected in the timber-frame construction, from planks/laths about $8 \mathrm{~cm}$ thick, which generally precludes the possibility of its use during the winter season. In addition, the house did not have a wooden floor and was provided with a stone stove/hearth, typical for a bath rather than a dwelling. However, the nature and richness of the inventory discovered on the occupational level (which included, among other objects, kitchen accessories and chess pieces) leaves little doubt as to the residential function of the building. It was probably used only during a polar day, as a subsidiary station. The second, slightly smaller building (cabin C) was only preliminarily surveyed, and its very poor preservation made a closer description impossible. However, one cannot rule out that it was this building that served as a dwelling proper. The discovery of kaolinite pipes in cabin A allowed the time of the building's use to be determined as around the mid- $18^{\text {th }}$ century (Chochorowski, Jasinski 1993a, 23, fig. 7).

house). However, they are covered with a thick layer of sand and gravel, and their full identification would be extremely difficult without conducting geophysical surveys or excavations. Thus, it seems likely that the Pomor hunting operations in this region were carried out on a larger scale.

${ }^{31}$ The cliff is inhabited by numerous bird colonies, and its vicinity was no doubt a good place for setting fox traps. In this context, one should consider the activity of the hunters primarily in autumn (?). 


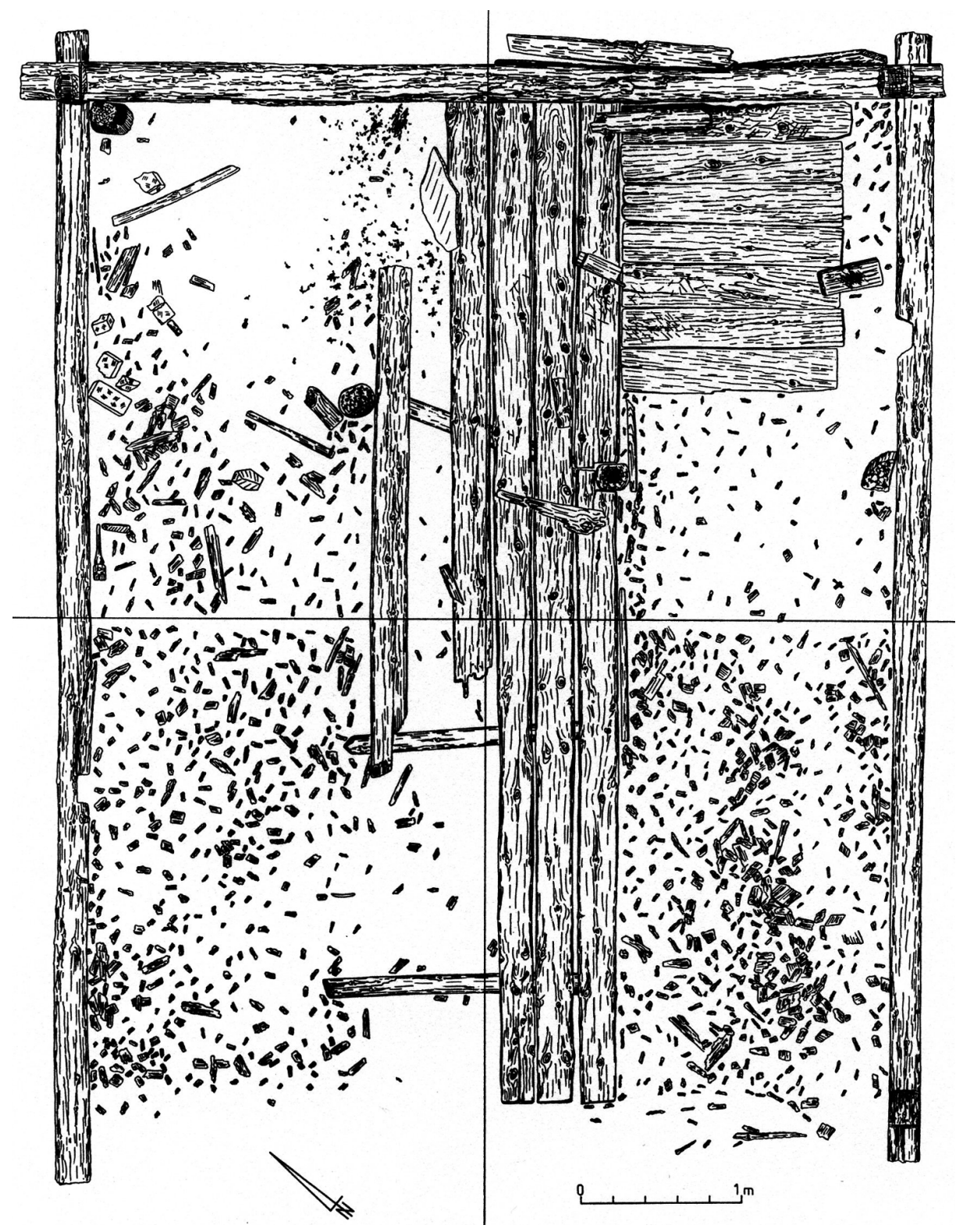

Fig. 25. Schönningholmane; remains of cabin B built from carefully hewn 'prefabricates' - view after cleaning

Little can be said about the Pomor cabin at Revela in Ariebukta, badly damaged by storm waves and dated dendrochronologically to "1639" (Chernykh 1987, pl. 2; Starkov 1998, pl. 3 and 4). It was comprised of a main room, about $8 \mathrm{~m}^{2}$ in floor surface, and a smaller entrance room. The ground beams were probably taken from driftwood, and the floor was made from shipwreck planks. The cabin was heated by a brick stove, and the nature of cultural deposits suggests prolonged use. 

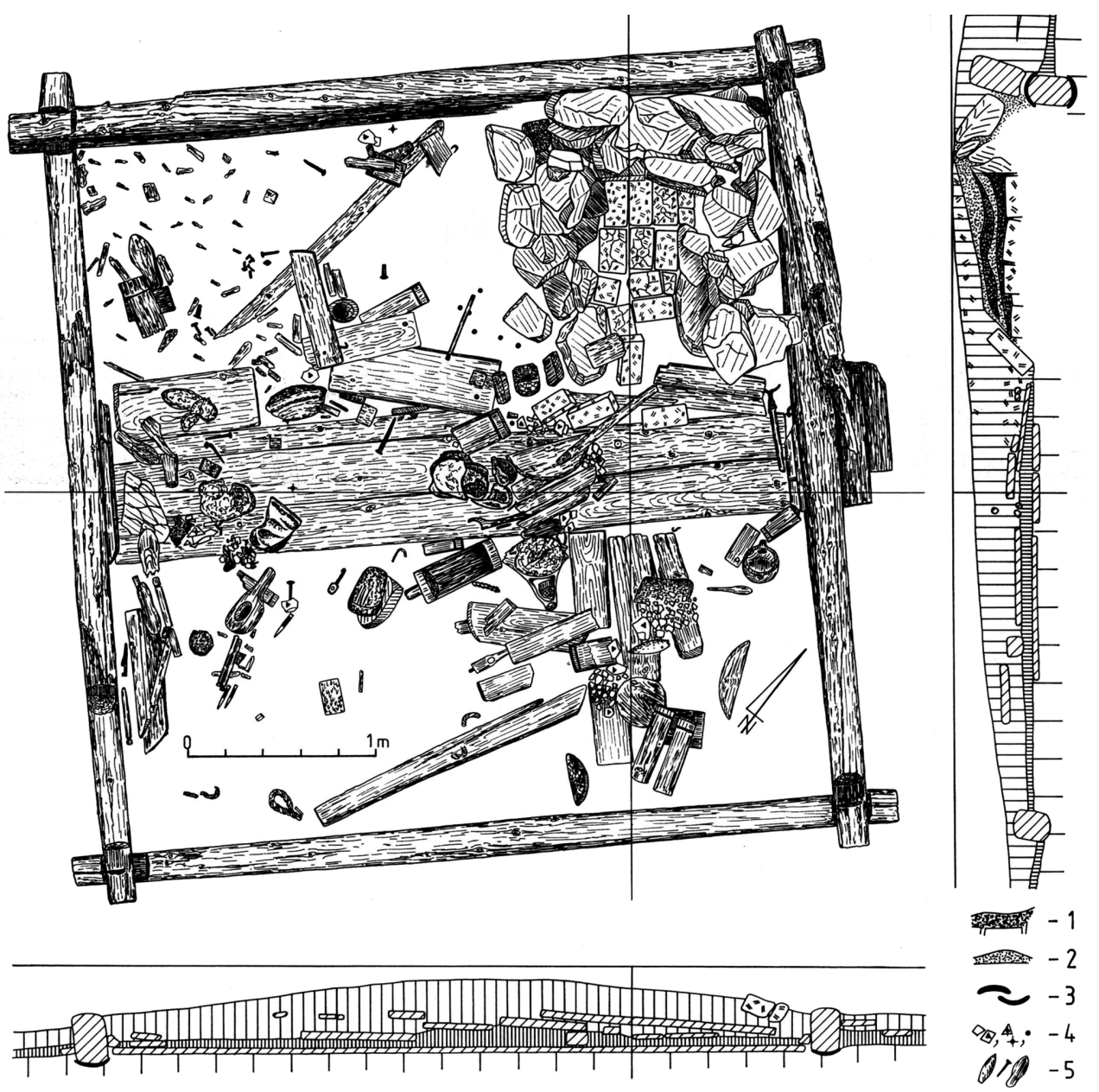

Fig. 26. Schönningholmane; occupational level in cabin $C$ built from 'prefabricates', with the ruins of stove/hearth and broken furniture

The house from Worcesterpynten on the northern side of the Hornsund's mouth, also explored by the Norwegian-Polish expedition in 1989 (Chochorowski, Jasinski 1993a, 36-49), stands out in this catalogue. It was a tiny $\left(5 \mathrm{~m}^{2}\right.$ in floor surface) cabin built from driftwood which had been little selected in terms of constructional usefulness (Fig. 31). The ground beams were made from massive, irregular tree trunks, only roughly hewn and cut askew. The construction also comprised shipwreck elements (e.g. a capstan drum used as a foundation for a brick stove), including details made from oak wood ${ }^{32}$. The cabin was built behind a monadnock, so that its eastern wall with the entrance was protected from the most vexing winds blowing from the fiord $\operatorname{side}^{33}$. From the north, a wall was erected from large boulders, which closed the area between

\footnotetext{
${ }^{32}$ Probably remains of ships of West European construction (possibly whalers).

${ }^{33}$ The place is quite far from the sea (about $80 \mathrm{~m}$ ) and more than 5 metres above its level.
} 


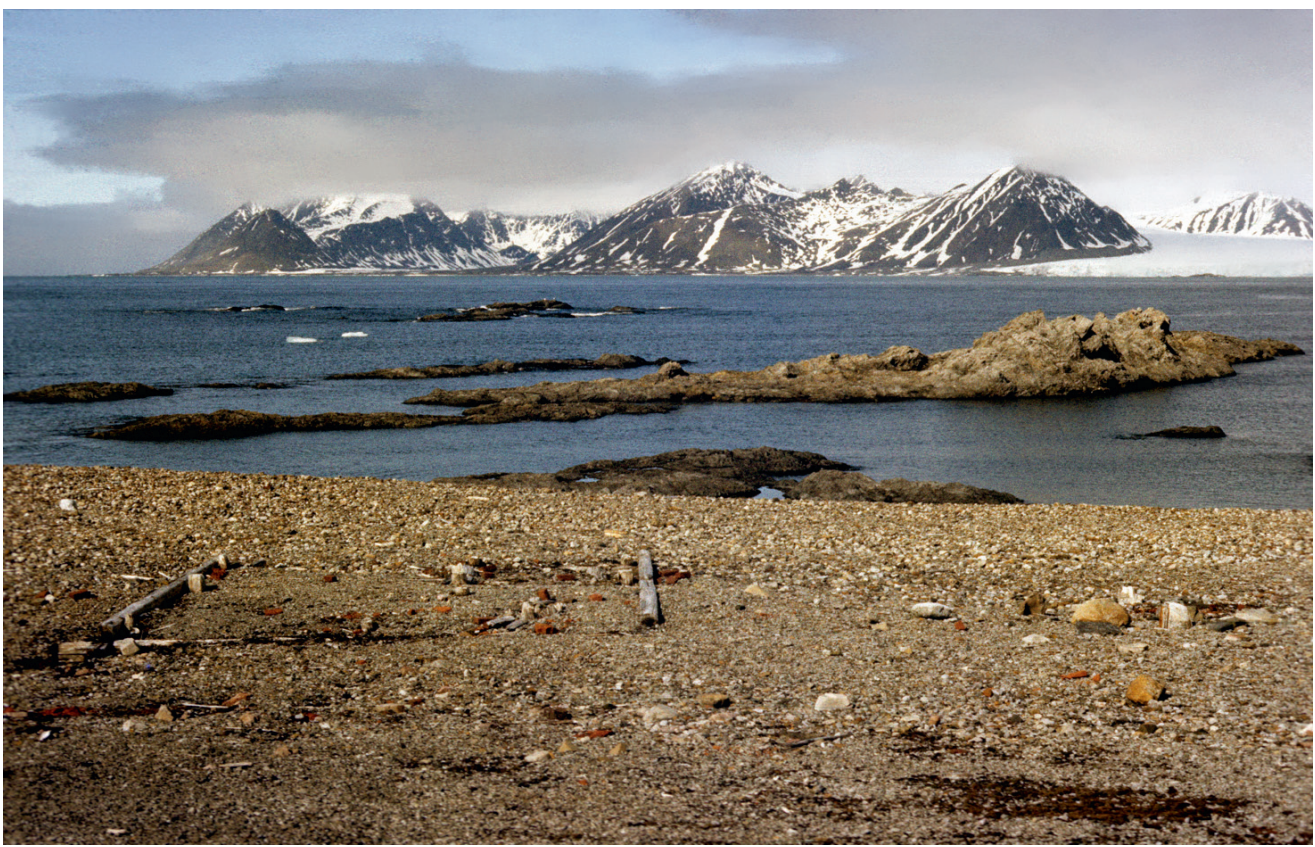

Fig. 27. Schönningholmane; cabin A situated vis-à-vis the navigable channel between the rocks - state of preservation at the ground surface level

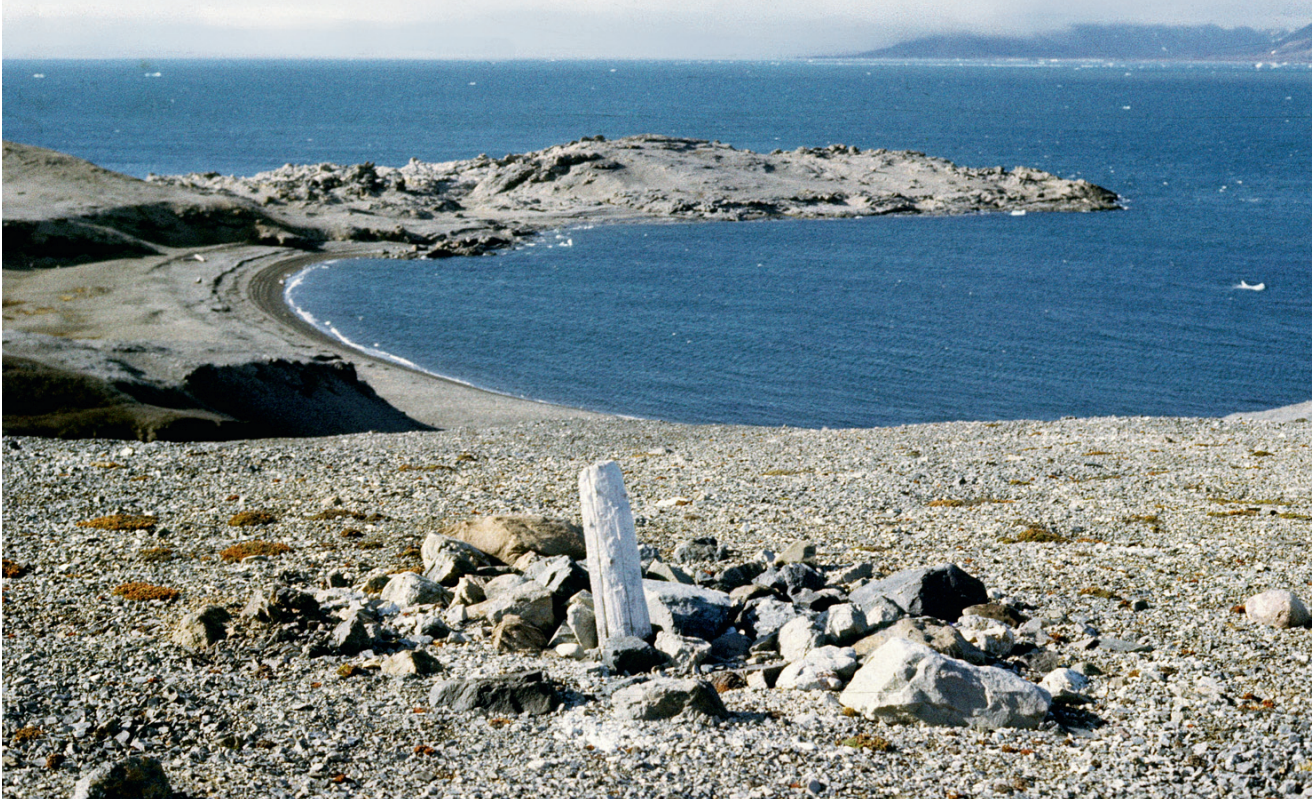

Fig. 28. Schönningholmane; remains of the monumental cross on a hill overlooking the station, with the view on the Hornsund mouth and Arkeologvika bay 

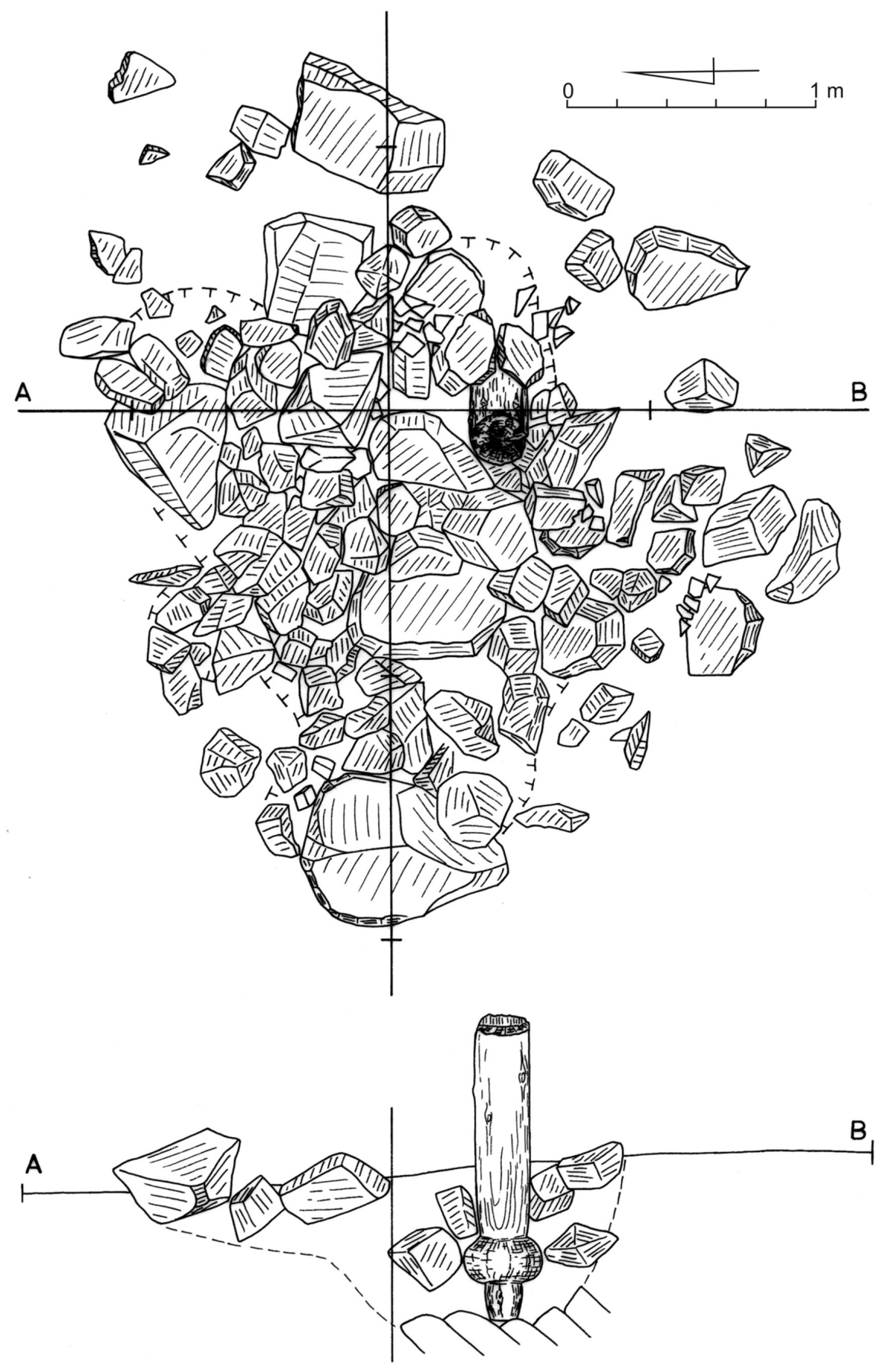

Fig. 29. Schönningholmane; plan and cross-section through the foundation of the cross set on a hill overlooking the station 


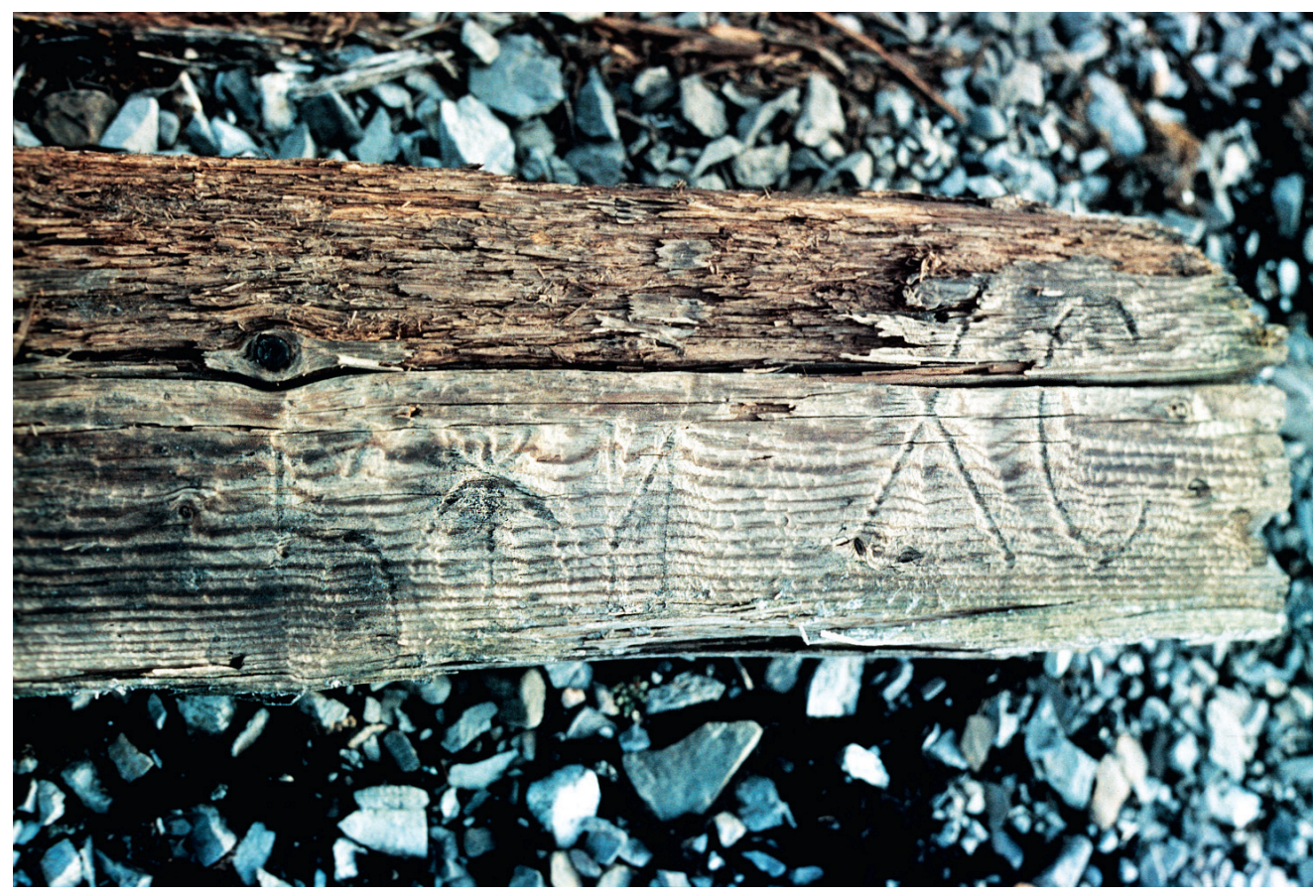

Fig. 30. Schönningholmane; inscription detail on the transversal arm of the cross

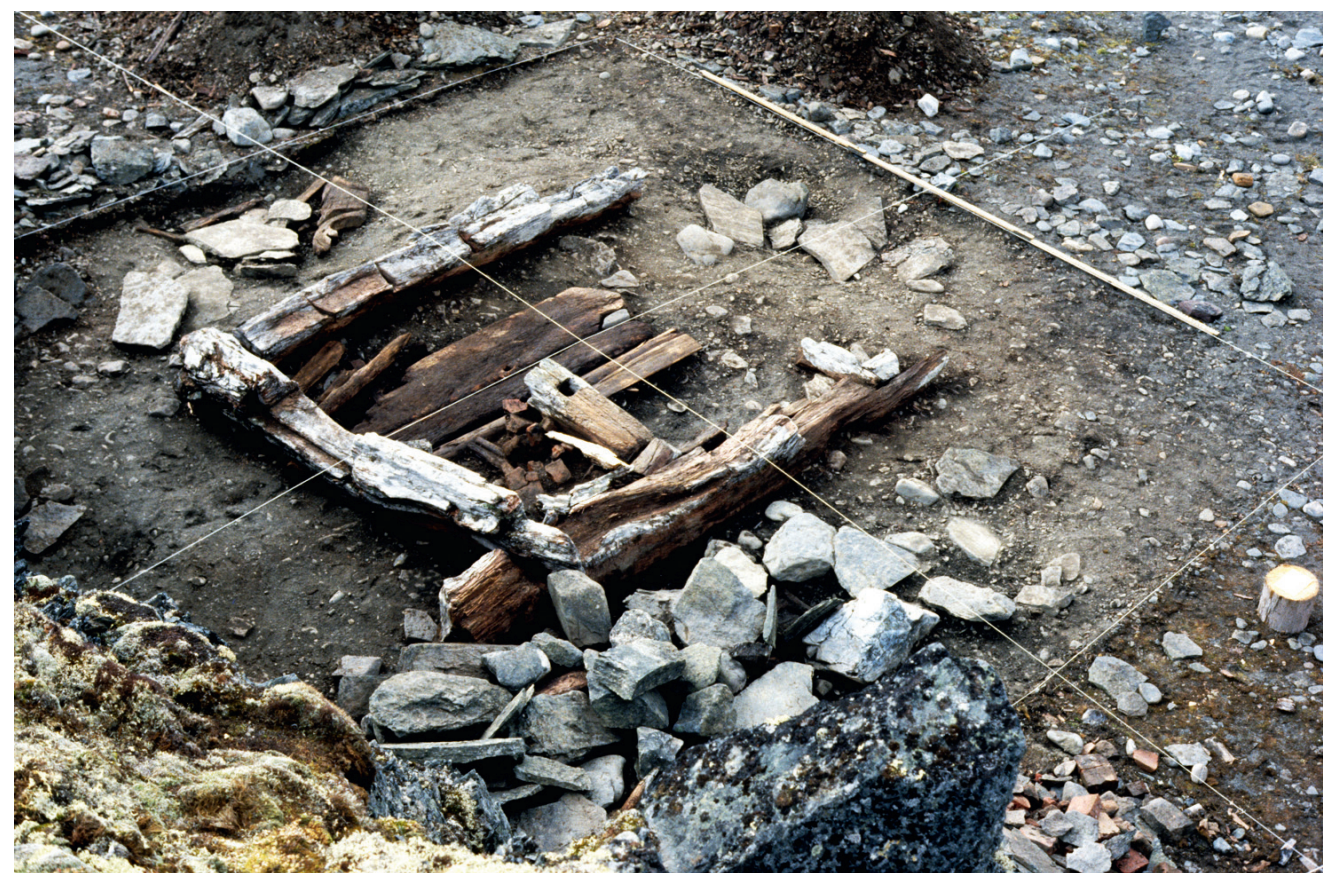

Fig. 31. Worcesterpynten; remains of cabin built from driftwood on the leeward side of a monadnock view after cleaning 
the entrance and the vertical wall of the monadnock, forming a kind of entrance hall, perhaps canopied. This solution much resembles what was recorded in cabin B on Palffyodden. It can be assumed that the building of the house was forced rather than pre-planned, perhaps under the pressure of time. The material used was driftwood, which did not even undergo any significant preselection from the perspective of its usefulness. On the other hand, the stove was built of bricks, which means the builders must have had access to such material as well. Perhaps it was recovered from an already damaged house, e.g. from the nearby cabin at the mouth of the Revelva. It is also worth noticing that the finds from the discussed cabin lacked artefacts associated with the typical production activity of hunters, such as shoemaker's lasts. But the finds did include an element of a musical instrument (balalaika's neck), and fragments of a primitive calendar, in the form of strips of wood with notches in regular arrangement: six transversal and one diagonal (Chochorowski, Jasinski 1993a, figs 23-24). The cabin's users (or user) had access to firearms, as evidenced by the discovery of lead balls, not completely finished - with traces of casting jets. The impression emerging from all of this is that the Worcesterpynten cabin was not directly associated with the realization of hunting strategy, reflecting instead some unplanned episode in the life of the Pomor hunters. If, however, it was to be interpreted as a kind of a hunting outpost ("stanok"), it would perhaps be linked with the "base" station (three-room building) on Russepynten ${ }^{34}$, about $6 \mathrm{~km}$ away from Worcesterpynten as the crow flies ${ }^{35}$, rather than with the groups operating on the southern side of Hornsund. Perhaps a similar role in relation to the large Russepynten station was also played by the one on Gnålodden, which marked the maximum range of its hunting area ${ }^{36}$ (which reached the northern coasts of Hornsund).

\section{Dendrochronology of timber from the Pomor stations in the Sørkappland and Horn- sund coasts}

The above review of Pomor stations in the Sørkappland and Hornsund coasts has revealed differences in their structure, in terms of the number of buildings, the time of their construction and exploitation, and the building materials used. Archaeological and historical data are insufficient for determining the chronological, and hence also functional, relationships among particular stations, which significantly hampers the assessment of basic indicators (e.g. chronological frameworks, frequency and intensity of operations) of Russian hunters' activity in the region, understood as an element of a broader historical process encompassing vast areas of the Arctic (Starkov 2008, 247-251). Perhaps, certain clues for such discussion could be derived from dendrochronological data, when used not as much for determining absolute chronology (which is extremely difficult given the diversity of building material, particularly in terms of its origin; let us mention for example drift wood - Häggblom 1982,

\footnotetext{
${ }^{34}$ The Russepynten station has been dated dendrochronologically by Russian scholars to AD 1775 (Starkov 1998, pl. 3 and 4).

${ }^{35}$ To the list of Pomor sites in this region one should add two base stations located on small islands (Fjørholmen and Store Dunøya) within the Dunøyane archipelago, to the north-west from the Hornsund mouth (Chochorowski, Jasinski 1995, 267-280). They were certainly used in the early $19^{\text {th }}$ century, as the Store Dunøya station was the scene of a tragic episode when 13 Russian hunters wintering there in 1818/1819 got murdered (Conway 1906, 270; Krawczyk 1995, 284-286).

${ }^{36}$ The borders of this area coincide with those which later developed in this region (i.e. between Hornsund in the south and the Torrel glacier in the north) within the frameworks of traditional Norwegian trapping (Rossnes 1990, 76-78, fig. 4).
} 
81-92; Eggertsson 1994, 4-8; Hellmann et al. 2013, 1-9) ${ }^{37}$ as temporal relationships between particular features. This particularly applies to the assessment of chronological cohesion of the building materials from particular buildings and stations, and potential contemporaneity (or its lack) of these sites. The problem is that the material used for constructing the stations in question was hugely diversified, in terms of both technological parameters and origin. As showed by the analysis of the remains of particular features, they were built from the following:

1. ready elements (prefabricates) in the form of carefully cut and hewn beams (and planks) brought from the continent, with all likelihood from the region of Pomorje ("Arkhangelsk north"') 38 ;

2. "raw", unworked beams most likely acquired from drift material, transported from the continent by sea currents ${ }^{39}$;

3. re-used elements of various constructions, in particular originating from damaged or dismantled ships ${ }^{40}$.

The above, unfortunately, does not exhaust the list of possible variants, since for each group one can theoretically consider many other options. The arising questions include the following:

1. were the prefabricates prepared from fresh material, or retrieved from some other buildings (brought from the continent - see e.g. Storå 1987, 127) by that time no longer needed?

2. could the "raw" beams resembling drift wood have been - for some reasons (e.g. as fuel - Starkov 1998, 48) - brought from the continent as well?

3. could the re-used ship elements have also been collected from drift material deposited on the shore (which could remain a valuable construction material for a long time), and not only from damaged or unnecessary and deliberately dismantled ships?

Therefore, the examination must also include the analysis of synchronicity (or the lack of such) between particular types of construction materials.

For the needs of a preliminary test, 26 wood samples were selected (Table 1) ${ }^{41}$, originating from the features explored by the Polish expedition in Sørkappland, and which covered the basic types of construction materials used by the Pomors in their hunting stations, namely:

- $\quad$ structural elements of houses looking like prefabricates brought from the continent (samples 7-9, 19, 21-23);

- "raw" drift wood most likely collected locally (samples 1, 20);

- $\quad$ planks from the boarding of grave 1 at Palffyodden (samples 24-25);

\footnotetext{
${ }^{37}$ The fundamental methodological problem can be formulated as follows: to what degree is the date of felling the tree, which means the dating of the construction material, tantamount to the date of erecting a building? (Chochorowski 1999, 11). The analysis of individual cases and the developed models indicate that regarding these two chronological facts as identical leads to creating a false picture.

${ }^{38}$ According to V. F. Starkov $(2008,250)$, nearly all of 113 samples originating from 36 Pomor buildings in Spitsbergen (except but one) point to the Arkhangelsk north as the place where the tree had been felled. ${ }^{39}$ One should take into account first of all the material transported by rivers which empty into the White (the Dźwina), Barents (the Peczora), and Kara Seas (in particular the Yenisei-Angara complex); see e.g. Eggertsson 1994, 1-9; 1994a, 9-10. The wood could have survived on the shores of Spitsbergen for many years without losing its value as a constructional material (e.g. Johansen 1998, 134-139), especially in emergency situations.

${ }^{40}$ In this case, it is difficult to determine whether this resulted from deliberate action or unpredictable coincidence.

${ }^{41}$ The small number of samples analysed resulted from logistical issues, i.e. the problems with transporting the samples to Poland in the circumstances of the 1980s when the research was being carried out, and from the preliminary nature of the test, whose main objective was to verify the reasonableness of such analyses.
} 
Table 1. Dendrochronological determinations for samples of construction material collected from sites investigated by the Jagiellonian University expedition in 1982-1987

\begin{tabular}{|c|c|c|c|c|c|}
\hline No. & Lab code & Sample description & Species & $\begin{array}{l}\text { Number of } \\
\text { rings }\end{array}$ & $\begin{array}{l}\text { Dating of the } \\
\text { sequence }\end{array}$ \\
\hline 1 & SPITS 7 & Schönningholmane, hut C, wall SW, beam & Larix sp. & 79 & \\
\hline 2 & SPITS 8 & Schönningholmane, hut C, wall NE, beam & Larix sp. & 88 & *115-202 \\
\hline 3 & SPITS 22 & Schönningholmane, hut C, wall NW, beam & Larix sp. & 134 & *71-204 \\
\hline 4 & SPITS 23 & Schönningholmane, hut C, wall NW, beam & Larix sp. & 130 & *73-202 \\
\hline 5 & SPITS 2 & Schönningholmane, shaft of monumental cross & Larix sp. & 157 & $* 5-161$ \\
\hline 6 & SPITS 26 & $\begin{array}{l}\text { Schönningholmane, diagonal arm of monumental } \\
\text { cross }\end{array}$ & Larix sp. & 58 & *103-160 \\
\hline 7 & SPITS 5 & Tørrflya, landing place 1 , wrecked boat, clamp & Pinus sp. & 109 & \#114-222 \\
\hline 8 & SPITS 6 & Tørrflya, landing place 1, wrecked boat, frame & Pinus sp. & 74 & \\
\hline 9 & SPITS 11 & $\begin{array}{l}\text { Tørrflya, landing place } 1 \text {, wrecked boat, deck } \\
\text { plank }\end{array}$ & Pinus sp. & 91 & \\
\hline 10 & SPITS 13 & Tørrflya, landing place 1 , wrecked boat, frame & Pinus sp. & 173 & \#1-173 \\
\hline 11 & SPITS 16 & Tørrflya, landing place 1 , wrecked boat, clamp & Pinus sp. & 128 & \\
\hline 12 & SPITS 18 & Tørrflya, landing place 1 , wrecked boat, frame & Pinus sp. & 54 & \#69-122 \\
\hline 13 & SPITS 1 & Bjørnbeinflyene, hut, beam from wall S & Larix sp. & 145 & *64-208 \\
\hline 14 & SPITS 12 & Bjørnbeinflyene, hut, floor & Pinus sp. & 54 & \\
\hline 15 & SPITS 20 & Bjørnbeinflyene, hut, beam from wall $\mathrm{N}$ & Larix sp. & 125 & \\
\hline 16 & SPITS 21 & Bjørnbeinflyene, hut, beam from wall $\mathrm{E}$ & Larix sp. & 202 & $* 1-202$ \\
\hline 17 & SPITS 15 & Bjørnbeinflyene, shaft of monumental cross & Pinus sp. & 173 & \#5-177 \\
\hline 18 & SPITS 9 & Palffyodden, hut A, beam from wall SW & Larix sp. & 94 & \\
\hline 19 & SPITS 14 & Palffyodden, hut A, floor, deck plank & Pinus sp. & 73 & \\
\hline 20 & SPITS 19 & Palffyodden, hut A, stove construction, post & Larix sp. & 73 & *64-136 \\
\hline 21 & SPITS 24 & Palffyodden, grave 1, plank from wooden frame & Larix sp. & 192 & *3-194 \\
\hline 22 & SPITS 25 & Palffyodden, grave 1, planks from wooden frame & Larix sp. & $42+55$ & \\
\hline 23 & SPITS 3 & Breineset, clamp from wrecked ship & Picea sp. & 142 & $1769-1910$ \\
\hline 24 & SPITS 4 & Breineset, clamp from wrecked ship & Picea sp. & 123 & 1787-1909 \\
\hline 25 & SPITS 17 & Breinesflya, detail from wrecked ship & Pinus sp. & 99 & \#105-203 \\
\hline 26 & SPITS 10 & Tørrflya, detail from wrecked ship & Pinus sp. & 70 & \\
\hline
\end{tabular}

- $\quad$ ship elements (deck planks) re-used when building a house (samples 12, 14);

- $\quad$ structural elements from a damaged boat (or small ship) from Tørrflya (samples 5-6, $11,13,16,18)$;

- $\quad$ structural elements of wrecked ships found scattered on the shore (samples $3-4,10,17)^{42}$.

${ }^{42}$ The dendrochronological analyses have been carried out in the Dendrochronological Laboratory in the Faculty of Geology, Geophysics, and Environmental Protection of the AGH-University of Science and Technology in Kraków. 
The analysis of these 26 wood samples (Table 1), representing nearly all possible categories of construction material and structural elements of damaged ships or boats, revealed certain diversity also in terms of tree species. All the samples originated from conifer trees, but three species were represented: larch Larix sp. (13 pcs), pine Pinus sp. (11 pcs) and spruce Picea sp. (2 pcs). The most popular material was larch, which prevailed among prefabricates brought from the continent. The majority (64\%) of the samples revealed long sequences of over 90 annual growth rings, and among them $20 \%$ were long-lived trees which grew for more than 150 years.

Correlations made using computer programmes (TSAP - Rinn 2005; TREE-RINGS package - Krawczyk, Krąpiec 1995), and visual comparisons of dendrograms allowed same-age sequences to be identified among samples representing particular tree species (Fig. 32). On this basis, the following chronologies were determined: SPITS_A3 (larch, 9 samples, 208 years), SPITS_B1 (pine, 5 samples, 222 years), and SPITS_C1 (spruce, 2 samples, 142 years). They were compared with the available standard curves both for driftwood and North Russian wood. The absolute chronology was established only for the spruce sequence, thanks to its correlation with the chronology of driftwood from Isfjorden $(\mathrm{t}=7)$, developed by Ó. Eggertsson and dated based on the chronological data from the Arkhangelsk region (Ó. Eggertsson pers. comm.). It spans the period of 1765-1910 AD (Table 1).

\section{Chronological relationships between buildings and stations in light of dendrochrono- logical data}

The obtained sequences are sufficiently long to attempt synchronisation of particular building episodes. They also facilitate the assessment of the Pomor activity in the discussed area. The data (Table 1; Fig. 32) show, for example, that larch beams used for the construction of cabin $\mathrm{C}$ (bath) in Schönningholmane originated from trees of virtually the same age (SPITS 8, 22, $23)^{43}$. As mentioned, the archaeological data clearly indicate that the three buildings of the Schönningholmane station were most likely erected in a single episode, from wood brought from the continent. The dendrochronological observations clearly support this view. Interestingly, however, the shaft of the monumental Orthodox cross (SPITS 2), raised at that time on a hill near the station, was made from the trunk of a larch tree cut down significantly earlier (by 43 years) ${ }^{44}$. A similar date (different by only 1 year) was also obtained for the diagonal arm of this cross (SPITS 26). In this case, either older beams were re-used or, more likely, a cross originally standing on the continent was dismantled and raised again near the $\operatorname{station}^{45}$, where

\footnotetext{
${ }^{43}$ Small differences (2 years) may stem from secondary processes (e.g. timber processing) and do not challenge the reliability of this observation. It is worth emphasising that the samples were cut out from the ground beams, so their connection with the moment of the station's construction raises absolutely no doubt. Furthermore, the building originally (i.e. when all the buildings were simultaneously used) served as a bath (bania), which means it was of strategic importance from the perspective of a group of a dozen or so hunters. One could even risk saying it was indispensable. One should not forget that, given the typical Russian mentality, the bath served not only utilitarian (hygienic), but also cultural (social) purposes.

${ }^{44}$ A hypothesis that the cross was set earlier, prior to the construction of the station, appears unlikely, since there are no features that could suggest a repeated use of this place by Russian hunters.

${ }^{45}$ As mentioned, the shape of the cross's lower termination, formed into what resembles a dome, argues for the second option. However, one cannot rule out that shaping the shaft's basis in this way had a symbolic meaning and reflects the great care and emotional investment in its execution; this would even more support the view that this was a special sign which accompanied the hunters undertaking the construction
} 


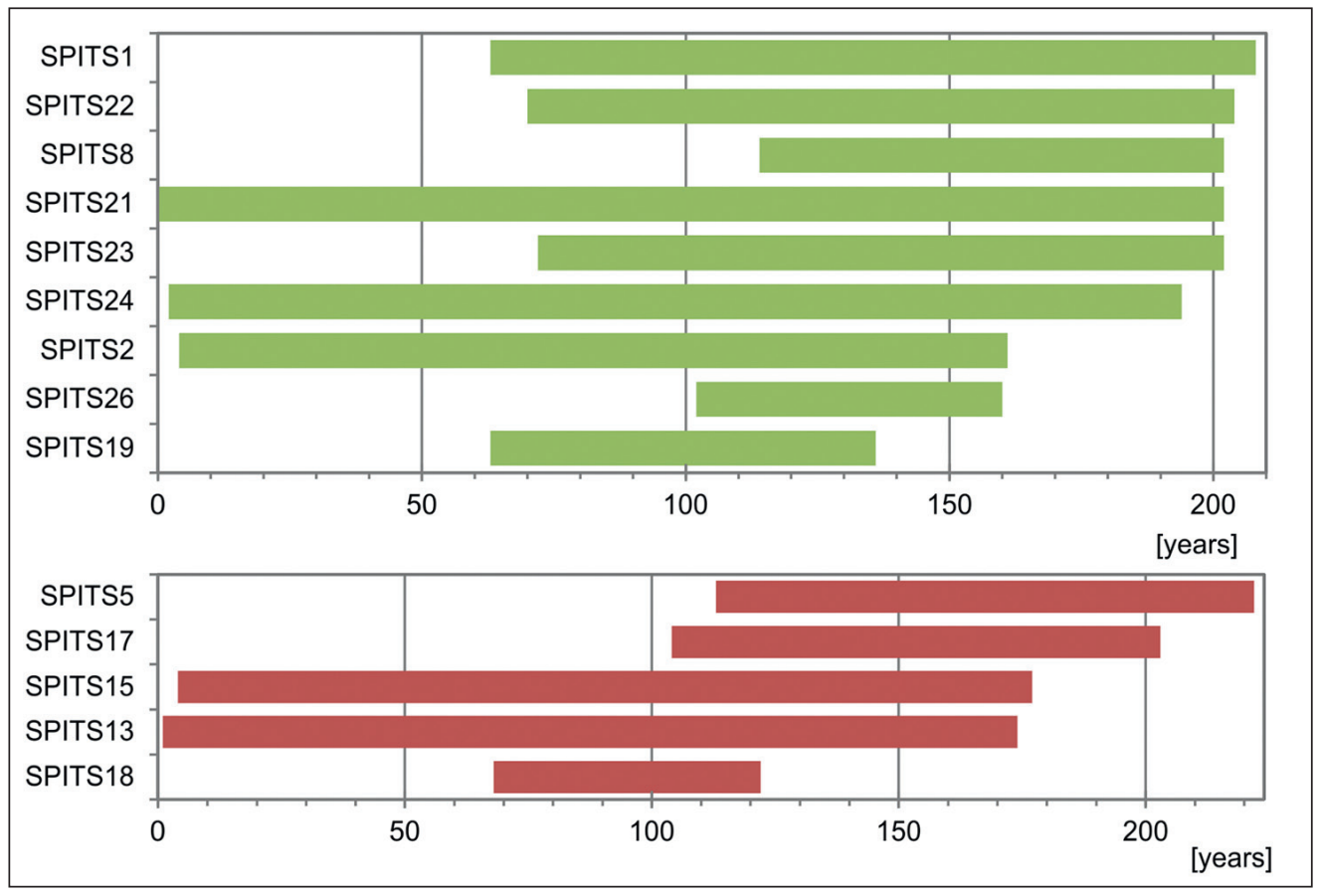

Fig. 32. Correlation block diagram of dendrochronological sequences of SPITS_A3 (larch - Larix sp., 208 years) and SPITS_B1 (pine - Pinus sp., 222 years) chronologies

it had a votive function and served as a navigational mark for sailors (Odintsov, Starkov 1985, 159-160).

The construction of the hunting cabin in Bjørnbeinflyene in the southern part of Sørkappland, near the Olsokbreen glacier that bars the access to the south along the coast, clearly synchronises with the building of the Schönningholmane station. A sill beam from this cabin (SPITS 21) produced the longest sequence (202 rings) and is same-age with two ground beams from cabin $\mathrm{C}$ in Schönningholmane (Table 1). Another sill beam from Bjørnbeinflyene (SPITS 1), which looks like an unworked, drift timber, is younger by 6 years. This may indicate that it was in fact brought from the continent, e.g. with another shipment of construction materials, or originated from "fresh" drift. Thus, it is possible that the Bjørnbeinflyene cabin, clearly an auxiliary location (stanok), was built a few years after the station on Schönningholmane as its subsidiary site allowing the extending of hunting operations over a much wider area ${ }^{46}$. It probably marked the southern border of the hunting area exploited by the hunters operating in the northern part of Sørkappland. However, it was also suited for winter stays and could have been used by small groups of hunters (or single hunters), who in their spare time engaged in shoe-making ${ }^{47}$. The importance of the place was emphasised by the monumental cross standing

of a new station from the very beginning. One could even consider its sacralisation by church officials on the continent (in Pomorje), in the place where the initiative for the enterprise appeared.

${ }^{46}$ The beam could have been brought with a new shipment of constructional material.

${ }^{47}$ As evidenced by numerous shoemaker's lasts found within the occupational layer deposited on the cabin's floor. 
nearby, which also served as a navigational mark ${ }^{48}$. The cross's shaft (SPITS 15) was made from the trunk of a pine (Pinus sp.), which makes its synchronisation with the constructional material (only Larix sp.) impossible. On the other hand, this allows for a comparison with the results obtained for the remains of a wrecked boat (small ship) recorded near Bjørnbeinflyene, in the Tørrflya site. The site was comprised of makeshift landing-places with mooring posts, and was no doubt used by the Pomor sailors and hunters during their hunting operations in this region $^{49}$. The promontory on which the Bjørnbeinflyene cabin was built is surrounded by shoals and skerries reaching far out into the sea, which makes direct approach and landing in that place virtually impossible. Therefore, the landing place at Tørrflya offered the only opportunity for the transport of timber for the construction of a cabin for hunters (as well as food and other supplies) ${ }^{50}$. What makes the Tørrflya finds particularly important is the discovery, next to landing place 1, of structural elements of a large boat or more likely a small ship (known as lodja) or karbas - sailboat. Discovered among the rubble of other elements were massive ribs, frames, deck planks, and hull planks "sewn" together with elastic twigs. All these elements no doubt belonged to the same vessel, built entirely of pine wood (Pinus sp.). The dendrochronological analysis allowed a relatively long sequence of 222 years to be compiled (Table 1). Major differences in the terminal sections of the sequence among the samples (with a maximum of 100 years - SPITS 5, 13,18) probably stem from considerable transformation of the elements during woodworking ${ }^{51}$, particularly necessary for the curved structural elements (ribs); at the same time, they indicate that the analysed elements were carved from relatively thick beams. It is also telling that a detail from a wrecked ship (SPITS 17) found on the Breinesflya coast (not far from Tørrflya) correlates with the above finds within the Pinus sp. sequence (105-203) (Table $1)^{52}$. Both sites probably reflect Pomor operations in this region at roughly the same time.

Thus, assuming that the landing place at Tørrflya and the wrecked ship link with a period when the Bjørnbeinflyene cabin was built and exploited, one can suppose that the youngest structural element from the ship (year 222 in the Pinus sp. sequence) is older than, or in an extreme case contemporary with, the youngest elements of the cabin (year 208 in the Larix sp. sequence). The ship, wrecked or possibly damaged and left on shore, was built before the construction of the Bjørnbeinflyene cabin rather than during this episode in the Pomor exploitation of Svalbard ${ }^{53}$. This would mean that the pine beam from which the monumental cross standing near the cabin was made (SPITS 15) is older by at least about 45 years than the material used

\footnotetext{
${ }^{48}$ At the base of the cross a shallow grave was discovered, with the burial partly damaged by animals (bears or foxes). It is a testimony to some, probably dramatic, events, as a lead ball was found between the ribs of the deceased (possibly a victim of murder or suicide).

${ }^{49}$ Today, the location is on the top of a high $(9-10 \mathrm{~m})$ terrace and is cut by a quite high cliff $(2-3 \mathrm{~m})$, about $100 \mathrm{~m}$ from the seashore. The landscape and the morphology of the coast changed due to the processes of accumulation and abrasion, whose dynamics probably relied on isoglaciostatic phenomena in the period of glacial transgression and then the deglaciation of Spitsbergen in the Little Ice Age (Starkov, Korjakin, Zav'jalov 1983, 110; Chochorowski 2002, 97-98).

${ }^{50}$ Among the finds from the cabin were large numbers of barrel staves and elements of other containers, whose transportation over larger distances (e.g. from Schönningholmane) was only possible by sea.

${ }^{51}$ They surely required more processing than simple beams used for making cabin walls.

${ }^{52}$ The dendrochronologically dated details from the Breineset shipwreck (SPITS 3 and 4) are most likely remains of a catastrophe that took place around 1910 (Fig. 34).

${ }^{53}$ It seems absolutely unlikely (given the position of the shipwreck in relations to the landing place, and taking into account the changes in the shoreline morphology in this place - see footnote 49) that the wreck was left there later or was an element of a natural drift of a younger date.
} 
for the cabin's construction. This need not come as a surprise if one recalls the situation recorded at Schönningholmane (with a difference of $43 / 44$ years within the Larix sp. sequence) ${ }^{54}$. The above may support the view that behaviours oriented towards sacralisation, such as setting crosses near hunting stations, referred to symbols that had already been considered important for the group prior to the undertaking of the enterprise ${ }^{55}$. Mounting a cross in a place chosen for the station was perhaps even the first act in a series of constructional and hunting operations, a sacral guarantee of success for the enterprise. The idea was not the sacralisation of the place alone (or even at all), but of the promysl as a tradition-sanctioned set of practices.

Placed centrally in the region, the Palffyodden station pre-dates the one at Schönningholmane by about 68 years in the Larix sp. sequence (Table 1). This, however, only applies to cabin A which, in light of the analysis of the topography and the constructional material, seems to be the oldest of the three dwellings (the same is suggested by the archaeological dating, estimated at ca. $1720 \mathrm{AD}^{56}$ ). Its correlation with other sites from Sørkappland whose relative positions within the Larix sp. sequence are known is unfortunately only possible thanks to one sample (SPITS 19), but an important one for the architecture of the building. The sample comes from a post which supported the platform on which the stove was built, which means it originates from an element connected with the initial phase of the cabin's construction ${ }^{57}$. As for the other two cabins from Palffyoddden, their chronological position in relation to cabin A cannot be precisely determined, but it seems certain that they are younger. A clue for determining the moment when the Palffyodden station ceased to function can be the position on the Larix sp. scale of a plank from the boarding of grave 1 (SPITS 24), which is 58 years younger than the post from cabin A. It all seems to indicate that the Palffyodden station continued to be used as long as around $1780 \mathrm{AD}$, with particular buildings successively added over the period. The small cemetery founded on a higher terrace (similarly to cabin A) was also successively used the five individual burials discovered there formed a complex stratigraphic sequence (Fig. 16). Two of them (graves 2 and 3), deposited on the ground surface, overlap with earlier graves dug into the gravel ${ }^{58}$.

\footnotetext{
${ }^{54}$ At the margin of this discussion a question arises whether the same explanation could possibly be proposed for the difference of 76 years between the dendrochronological dating of the cross from Skolteneset (1761 AD) and the historical dating of this station (1837 AD) confirmed by the discovery of the comb bearing the inscription "in 1837").

${ }^{55}$ In this context it is interesting to note a series of dendrochronological datings (Chernykh 1987, pl. 2; 1990, 116-117) from a Russian station at Russekeila in Isfjorden, linked with the activity of the legendary Pomor hunter Ivan Starostin, who had wintered there for 32 (Keilhau 1831, 239), or possibly even 39! (Conway 1906, 272-273) seasons (including 15 in a row), and died in 1826. Three buildings comprising the station produced the dates of 1753, $1762(1754,1759,1761 \times 2$ and $1762 \times 3)$ and 1778 (Kirchhefer 2003, 323), and four crosses were dated to 1757 (Russekeila 2), 1776, 1778, and 1782. This leaves no doubt that crosses could be erected during the exploitation of stations as well, perhaps in connection with subsequent stages of their development, but possibly also from ideological/symbolic reasons, sanctioned by the norms of religious life.

${ }^{56}$ This, at the same time, means that the cabin at Bjørnbeinflyene, erected (judging from the Larix sp. sequence) 72 years later, can be dated ca. $1790 \mathrm{AD}$, which corresponds well with the chronological frameworks determined for this cabin thanks to the discovery of a kaolinite tobacco pipe (1770-1810, with the focus on the late $18^{\text {th }}$ century).

${ }^{57}$ Of course, one cannot rule out that the stove was re-built in the already existing building, but this would make the cabin even older than suggested by the position of sample SPITS 19 on the Larix sp. scale.

${ }^{58}$ One explanation of the fact that some of the deceased were buried on the stone constructions of the older graves can be problems with digging a proper pit during the polar winter. Nevertheless, a chronological
} 
The above observations make it possible to present the most probable model of how the Palffyodden station was founded and functioned. First, cabin A was built around 1720 on a high berm crest, in a place which was prominent but at the same time exposed to strong winds ${ }^{59}$. At about the same time the first burials were deposited to the south-west of the cabin, and thus a small cemetery was founded. Next, in a much better sheltered place cabin $\mathrm{C}$ was built, which was used (as suggested by the fragments of kaolinite pipes discovered there) around 17501760 AD. Cabin B was built last, in a place sheltered by a monadnock from vexing fen winds blowing in from the fiord ${ }^{60}$. The chronological frameworks of the station can be established as no less than 60 years (more or less three generations of hunters), and this is also confirmed by the position of the post from cabin A (SPITS 19) in relation to the plank from grave 1 (SPITS 24) within the Larix sp. sequence. Thus, it seems likely that the station still remained in use in the period when the generation of hunters who built and exploited the Schönningholmane station and the auxiliary one at Bjørnbeinflyene was active.

\section{Chronology of the Pomor stations in the Sørkappland and Hornsund coasts in light of dendrochronlogical and radiocarbon analyses}

In the heyday of the Pomor promysl in Sørkappland, all these stations formed one system, exploited by an artel of hunters operating between the Hornsund fiord in the north and the Olsokbreen glacier in the south. The picture emerging from the dendrochronological analyses (a timespan of approx. 80/100 years for the functioning of the Pomor promysl in the north of Sørkappland) is to a large degree consistent with the chronological frameworks established for this phenomenon based on archaeological and historical data (from ca 1720 to 1837 AD), but clearly disagrees with the vision of a chronology which takes as a starting point the dendrochronological determinations of a pre-Barents date. Of course, what remains to be solved is the problem of the absolute dating of the analysed Larix sp. and Pinus sp. sequences. Since they could not be dated, as mentioned, on the basis of the available absolute chronologies of the larch and pine wood, the only way to approximately determine their age was by means of wiggle-matching. The method relies on the analysis of wood samples that have been previously relatively dated dendrochronologically. The radiocarbon analysis of such samples allows a "floating" fragment of the calibration curve to be developed, which is next matched with the main calibration curve, in our case IntCal13 (Reimer et al. 2013). The mathematical grounds

succession within a closer undetermined period of time leaves no doubt. However, grave 1 with the burial boarded with planks was not part of the mentioned stratigraphic sequence, so its chronological relationship with other burials cannot be stratigraphically determined. But it is interesting to note its social context - the grave held the remains of a well-built man approximately 173 tall, who died at the age of 30-40 years. He was wearing a splendid gilded cross on his neck, and his body (the only such case in the cemetery) was additionally secured with thick planks. Therefore, he could have been a person of outstanding status, perhaps acting as kormshchik of a group of hunters operating in the Palffyodden region (Chochorowski 2012, 669-670). This emphasises the role of Palffyodden as a base station (stanovishche) in the structure of the Pomor promysl in Sörkappland.

${ }^{59}$ The choice of Palffyodden as a central place of the Pomor hunting activity (in its early stage) was justified by its conspicuous location from the perspective of navigational conditions in the area. The place was easily recognisable due to the prominent massif of Hohenloehefjellet (614 m. a.s.l.), an excellent landmark for sailors.

${ }^{60}$ This is indicative of a good knowledge of local weather and (indirectly) shows the accumulation of experience resulting from the prolonged use of this place. 
of this method were described by Bronk Ramsey et al. (2001). Wiggle-matching allows for a precision much greater than with single radiocarbon dates.

The samples prepared for the radiocarbon analysis of the SPITS_A3 chronology (Larix sp.) included four samples from beams SPITS 1 (ground beams from Bjørnbeinflyene) and SPITS 2 (the shaft of the Schönningholmane cross), 10 tree-rings each, with the middles of ranges falling respectively to year 5, 105, 145, and 195 in the sequence (Table 2$)^{61}$. The results show that the youngest rings of the larch sequence cannot be earlier than ca $1751 \mathrm{AD}$ (Figs 33 and 34), and their most probable dating is to the second half of the $18^{\text {th }}$ century $(1751-1798$ AD $-95.4 \%$ probability). Given that the samples were taken from the construction of the Bjørnbeinflyene cabin (archaeologically dated to 1770-1810) and the cross from the Schönningholmane station (built at roughly the same time) which pre-dated the station's foundation by about 43 years, the consistency of the results seems very far reaching. The same procedure was applied to the pine wood chronology SPITS_B1 (Pinus sp.). Also in this case, four sequences of tree-rings were collected from samples SPITS 13 (a rib from the Tørrflya shipwreck), SPITS 15 (the shaft of the monumental cross from Bjørnbeinflyene), and SPITS 17 (a detail from a damaged ship - driftwood from Breinesflya), with the middles of the ranges falling in year 3, 101, 163, and 197 in the SPITS_B1 sequence (Table 2). Wiggle-matching results (Figs 35 and 36) allow one

Table 2. Sample description and conventional ages obtained for selected tree-rings from the analysed wooden elements belonging to SPITS_A3 (*) and SPITS_B1 (\#) chronologies

\begin{tabular}{|l|l|l|l|}
\hline \multicolumn{1}{|c|}{ Sample description } & \multicolumn{1}{c|}{ Lab code } & \multicolumn{1}{c|}{${ }^{14} \mathrm{C}$ age $(\mathrm{BP})$} & \multicolumn{1}{c|}{ Position in tree-ring chronology ${ }^{\mathrm{a}}$} \\
\hline SPITS2/1 & MKL-2749 & $330 \pm 50$ & $* 1-10$ \\
\hline SPITS2/2 & MKL-2750 & $180 \pm 30$ & $* 101-109$ \\
\hline SPITS1/4 & MKL-3116 & $110 \pm 30$ & $* 141-149$ \\
\hline SPITS1/3 & Ki-11304 & $170 \pm 50$ & $* 191-199$ \\
\hline SPITS13/1 & Ki-11302 & $380 \pm 50$ & $\# 1-5$ \\
\hline SPITS13/2 & Ki-11303 & $230 \pm 50$ & $\# 97-105$ \\
\hline SPITS15/2 & MKL-3117 & $170 \pm 30$ & $\# 150-177$ \\
\hline SPITS17/1 & Ki-11305 & $70 \pm 50$ & $\# 193-201$ \\
\hline
\end{tabular}

${ }^{\text {a }}$ Position of tree rings in chronology SPITS_A3 (*) and SPITS_B1 (\#), used in wiggle-matching analysis

to claim that the dating of the youngest rings of the pine sequence falls within between 1718 and $1760 \mathrm{AD}$ (31.1\% probability), 1772-1808 (31.7\% probability), or $1837-1869 \mathrm{AD}(32.6 \%$ probability). Taking into account the archaeological and historical data about the activity of the Pomir sailors in the region, the first and second of these options seem most plausible, although the last one does not contradict historical facts either. The results also confirm that the traces of sailing activity on Tørrflya and nearby Breinesflya, where the wrecked Pomor kocha ships were found, are indeed linked with the episode of the Bjørnbeinflyene cabin construction (1770-1810). A general conclusion emerging from these findings is that the oldest datings basically do not go back beyond the early $18^{\text {th }}$ century.

${ }^{61}$ The analyses have been carried out by N. Kovaljukh and V. Skripkin in the Kiev laboratory (Ki-1130211305) and by M. Krąpiec in Kraków (MKL-2749-2750 and 3116-3117). 


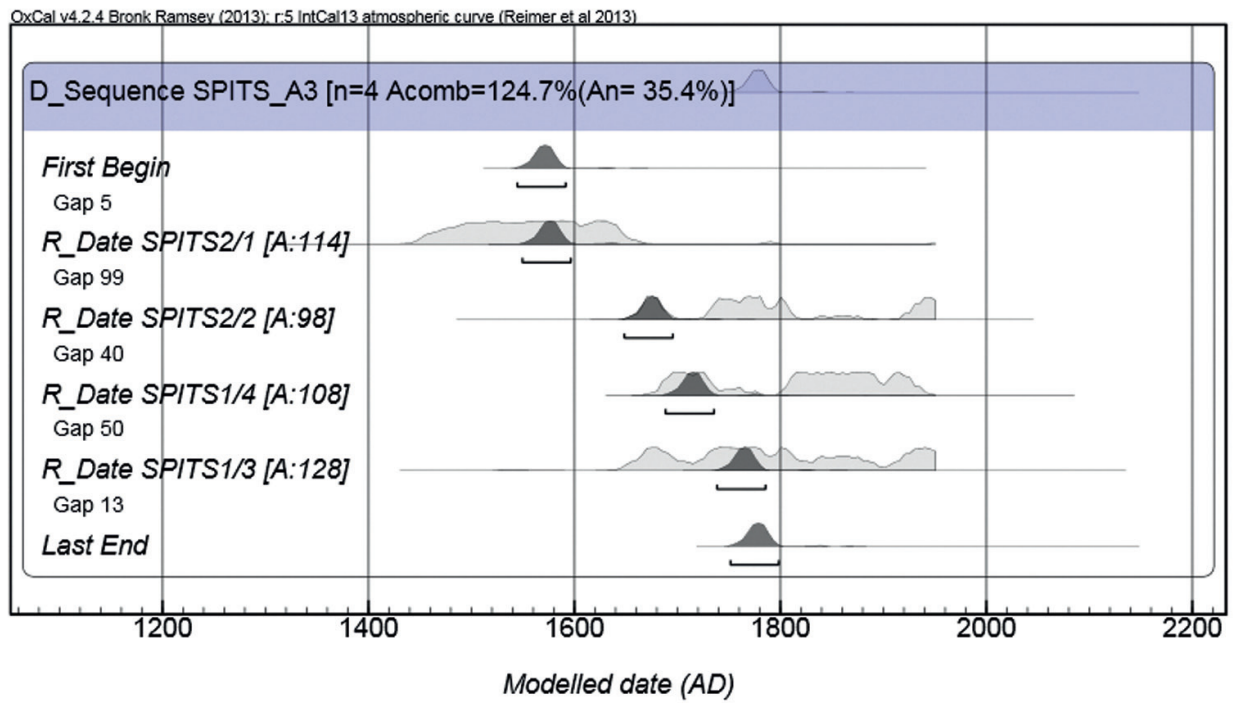

Fig. 33. Wiggle-matching results for the floating chronology SPITS_A3. The lower diagram presents probability distribution and calibrated position of cutting down the trees of the larch chronology

\section{Diagnosis}

The relics of Russian hunting stations on the coasts of Sørkappland, between the Olsokbreen glacier in the south and the Hornsund fiord in the north, are the material remains of a functionally autonomous organism, whose genesis and historical development were marked by internal logic and rationality. In the initial period of their activity, Pomor sailors and hunters exploring the coastal hunting grounds of the southern Spitsbergen choose as their base station the Palffyodden promontory on the southern side of the Hornsund mouth, stretching into the sea and highly conspicuous due to the characteristic cone of the Hohenlohefjellet massif (614 m. a.s.1.). In doing so, they somehow repeated the choice made by West European sailors who in the very same area, in Hornsund, made their first landing on the Svalbard shores in 1610. The Palffyodden vicinity, dotted with skerries, rocky islands, and promontories but also with sheltered beaches in small bays, most likely abounded in walruses and was regularly crossed by polar bears, although it did not provide safe anchorage. Probably in the early $18^{\text {th }}$ century (ca 1720?) the first cabin was built in Palffyodden, which at any rate was situated in a rather inconvenient place exposed to strong winds blowing in from both the sea and the fiord side. Nevertheless, its strategic location meant that Plafyodden remained a good starting point for subsequent generations of hunters in their exploitation of coastal hunting grounds, both towards the fiord and to the south, down to the barrier of the Olsok glacier ${ }^{62}$. For this reason, other cabins were subsequently built (cabin C - ca. 1750-1760; cabin B - at the close of the $18^{\text {th }}$ century?), each time better fitted into the landscape and better protected from harsh weather. The long duration and successive nature of the operations are symbolised by the small

\footnotetext{
${ }^{62}$ In the same place, in Palffyodden, in a later period Norwegian trappers hunting primarily for polar bears and foxes built their hus dwellings.
} 


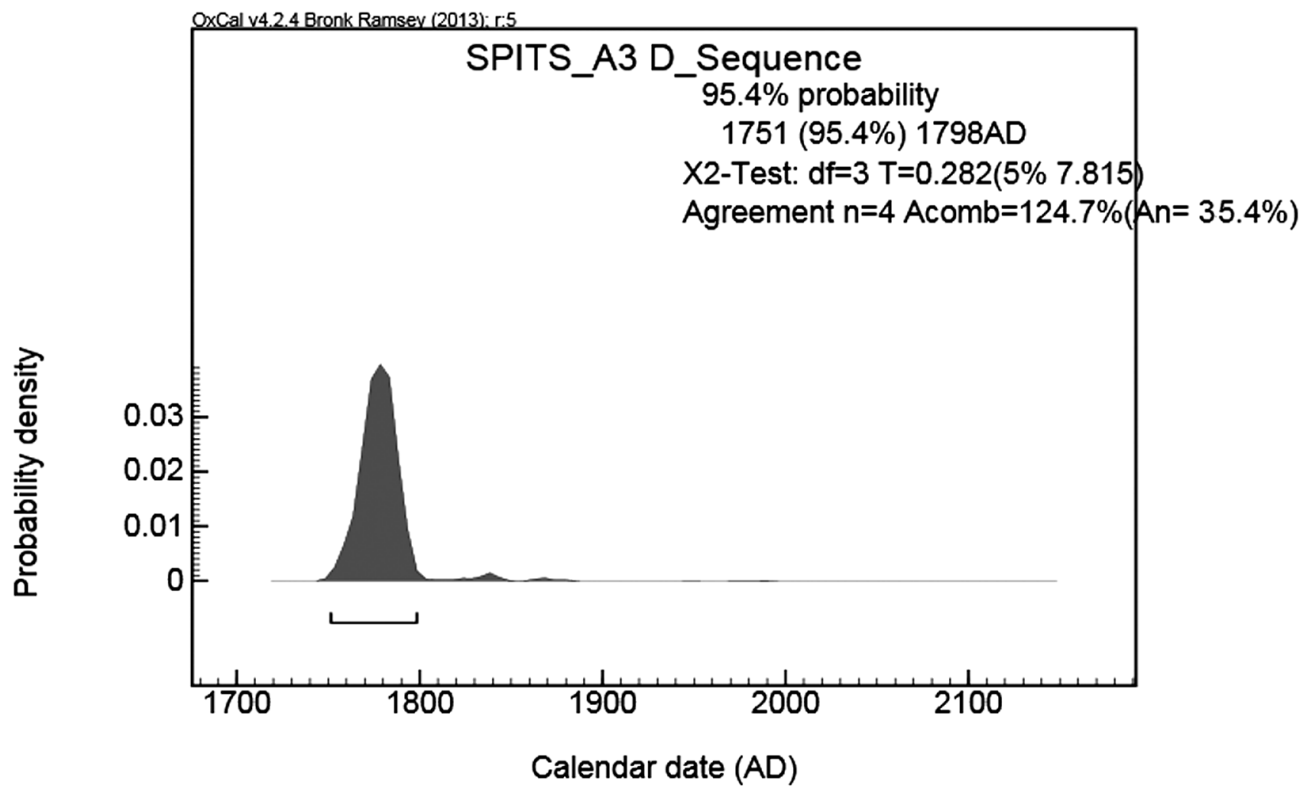

Fig. 34. Probability distribution and calibrated position of cutting down the trees of the larch chronology (Larix sp.) SPITS_A3

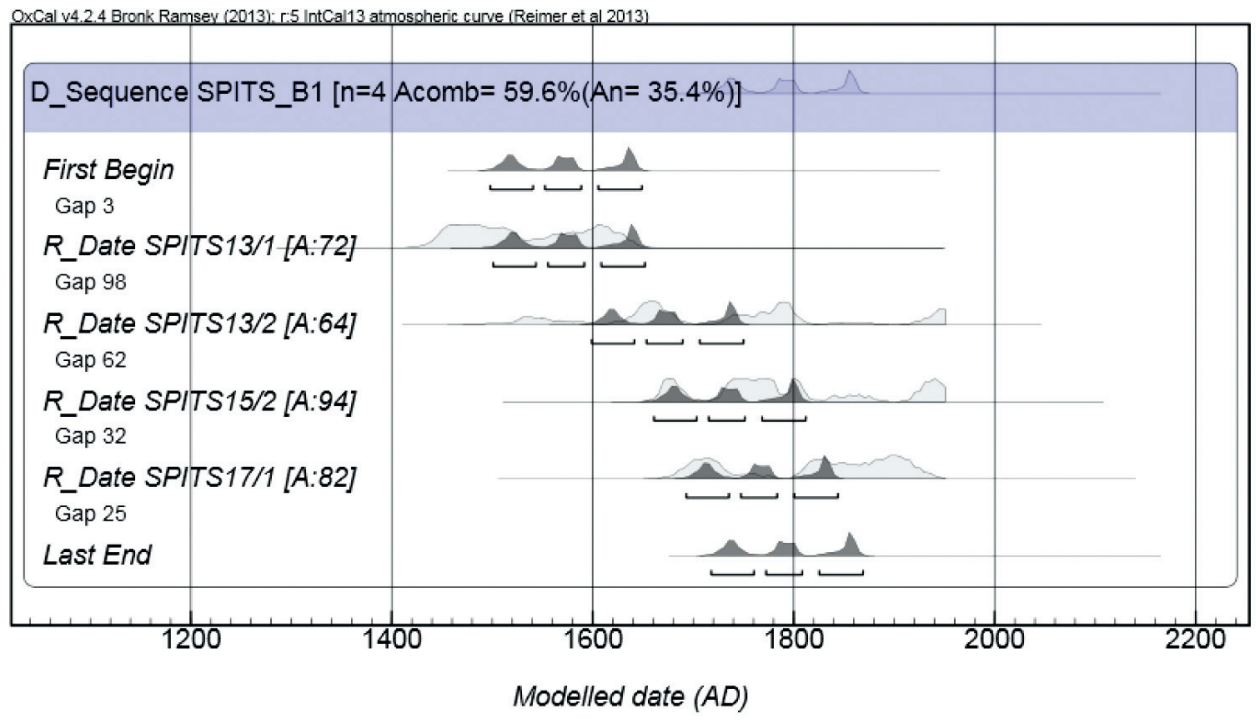

Fig. 35. Wiggle-matching results for the floating chronology SPITS_B1. The lower diagram presents probability distribution and calibrated position of cutting down the trees of the pine chronology 


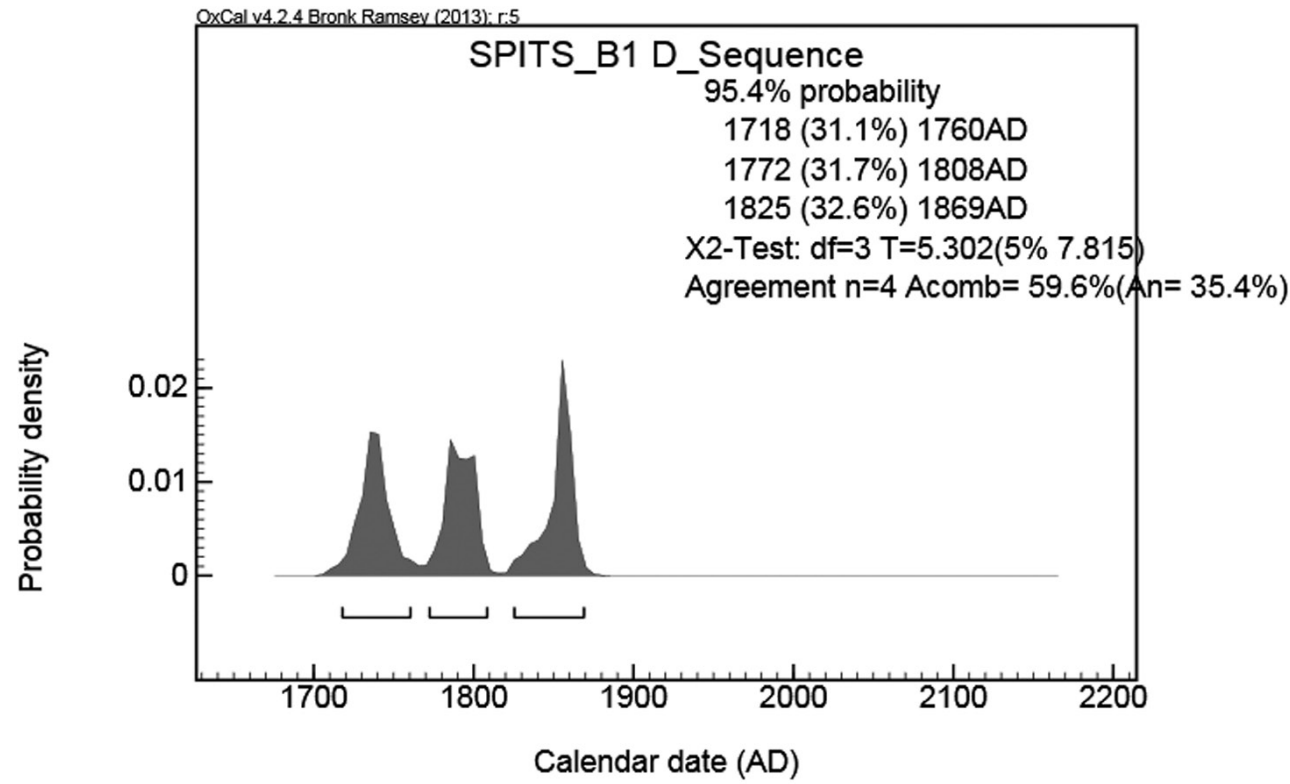

Fig. 36. Probability distribution and calibrated position of cutting down the trees of the pine chronology (Pinus sp.) SPITS_B1

cemetery established near the station buildings, in a topographic position corresponding to the oldest dwelling (cabin A). A successive exploitation of the place by hunters from the same group (possibly family or lineage) is also suggested by the accumulation of experience and knowledge about local weather and topographic conditions. It was probably exactly thanks to this accumulation of knowledge about the topography, hunting opportunities, and navigational conditions in this part of Sørkappland, that in the last decades of the $18^{\text {th }}$ century, in the heyday of their hunting operations, the Pomors established a new station at Schönningholmane. This time they choose perhaps the best suited place, near an excellent anchorage in Arkeologvika. This new location was at the same time one of the most conspicuous places in the Hornsund landscape, at the extension of the massive range of Wurmbrandegga (494 m. a.s.1.), and offered a good starting point for developing operations both along the Sørkappland coast and into the fiord. This time a large base station was built in a single episode, which served for an organised group (artel) of hunters. The extent of hunting operations was probably broadened by auxiliary stations: the youngest building at Palffyodden (cabin B) and - built purposely on the southern fringes of the hunting territory - the Bjørnbeinflyene cabin. Incidentally, these borders of the Pomor hunting territory on the southern side of Hornsund (Figs 14 and 37) were later repeated in the operations of Norwegian trappers (Rossnes 1990, fig. 4). All this enterprise was not only pre-planned and carried out with a flourish, but also sacredly sanctioned in line with the norms typical of the religious beliefs of the Pomors ${ }^{63}$. It seems quite likely that the final episode in the

${ }^{63}$ It is worth recalling here that a significant part of the Pomor hunters operating in Svalbard (Grumanlany) originated from the Old Believers community (Chochorowski 2012, 670-675). 


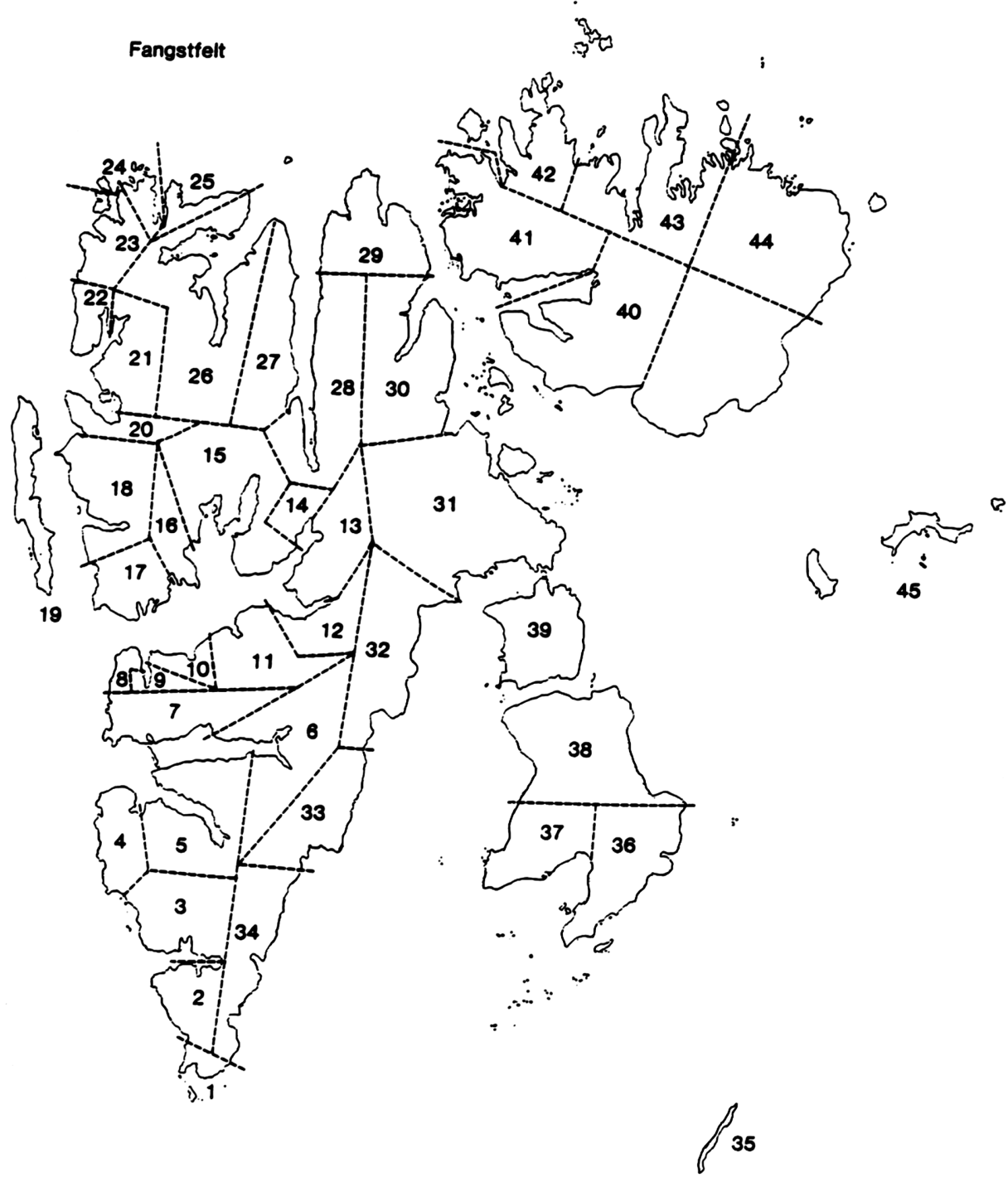

Fig. 37. Hunting ranges of Norwegian trappers, after G. Rossnes (1990) (no 2 - northern Sørkappland/ southern side of Hornsund)

Russian promysl in this region, dated probably to the first quarter of the $19^{\text {th }}$ century, was the activity of small groups or single hunters, who exploited the single cabins that were still usable and suited for wintering (e.g. Bjørnbeinflyene, cabin C at Schönningholmaene, or cabin B at Palffyodden). This is well illustrated by the 32 (Keilhau 1831, 239), or even 39! (Conway 1906, 272-273) winterings (including 15 in a row) of the nestor of Russian promyshlenniki Ivan Starostin, who died in 1826 and was buried next to his station at the southern side of the Isfiord mouth (Russekeila near Starostin Kapp - Ovsiannikov, Starkov 1985-1986, 123). In this way, the focus of the Pomor hunting activity gradually shifted from 'industrial scale' enterprises, 
which lost their economic rationale ${ }^{64}$, towards individual actions, later typical of the Norwegian trappers (Rossnes 1990), which were primarily oriented towards furs and hides (bear, fox, reindeer), and eider down feather. It was Pomor hunters, after all, who accompanied the first Norwegian trappers where the latter first appeared in Svalbard hunting grounds in 1775 (Keilhau 1831, 232; Conway 1906, 268-276; Löwenigh 1989, 124; Lønø 1991, 9-11) in an attempt to explore the still not fully depleted natural resources of the archipelago. Thus, the picture of the Russian promysl and its development emerging from the dendrochronological determinations is generally consistent with what is known about the chronology of this phenomenon based on historical data (Arlov 1988, 140, Jasinski 1993, 35-36; Hultgreen 2000, 267-280, Dadykina et al. 2017, 50-69) ${ }^{65}$.

\section{Struktura i chronologia rosyjskich stacji łowieckich na wybrzeżach Sørkapplandu i w strefie Hornsundu (Spitsbergen)}

Według opublikowanych przez badaczy radzieckich danych dendrochronologicznych (Zav'jalov, Starkov 1987, 248), a także istniejących informacji historycznych, ramy chronologiczne pomorskiego łowiectwa, tzw. promysla, w południowej części Spitsbergenu, miały wynosić około 274 lata. Najstarsza data dla drewna ze stanowiska Mosvatnet 2 na Sørkappøya to „1563 rok”, zaś informacja historyczna o ostatnim w tym rejonie zimowaniu rosyjskich łowców w stacji Skoltenestet, odnosi się do ,roku 1837”' (Conway 1906, 275 276). Przesłanki te nie są jednak wystarczające dla ustalenia wzajemnych relacji chronologicznych, a co za tym idzie - również funkcjonalnych, pomiędzy poszczególnymi stacjami. Niewątpliwie punktem wyjścia takiej refleksji mogłaby być analiza struktury (liczba i charakter obiektów, rodzaj budulca - Chochorowski, Jasinski 1993, 1-33) oraz dendrochronologiczne datowanie pomorskich stacji bazowych (stanovishch) i pojedynczych domków (stankov), a także śladów aktywności żeglarskiej, zidentyfikowanych w południowej części Spisbergenu; na wybrzeżach Sørkapplandu i fiordu Hornsund. Celem pozyskania i analizy oznaczeń dendrochronologicznych byłoby nie tyle określenie chronologii absolutnej poszczególnych obiektów (co jest niezwykle trudne wobec różnorodności budulca, zwłaszcza jego pochodzenia, szczególnie np. drewna

\footnotetext{
${ }^{64}$ Mainly due to the shrinking numbers of walruses which were the primary (though not only) target of the Russian promysl. The last episode in the history of the organised promysl was the tragic winter stay of an artel of 18 men in Raudfjorden (north-western part of West Spitsbergen) in the 1851/52 season, of which only six people returned home (Carlheim-Gyllensköld 1900, 156; Conway 1906, 275-276).

${ }^{65}$ Important for the assessment of the credibility of this claim are the results recently published in Acta Borealia (Dadykina et al. 2017, 50-69). They show that the oldest information in the Russian archives which concern Pomor ships departing for Svalbard (Grumant) originate from 1709 (a ship of the Menshikov company sent from Arkhangelsk with a crew of Russians and foreigners). According to the archive data, in the $18^{\text {th }}$ century the shipment going to Grumant made up $1 \%$ of an overall Pomor hunting activity. The information collected by the quoted authors (Dadykina et al. 2017, table 3) confirms that in the heyday of Russian hunters' activity, at the close of the $18^{\text {th }}$ century, the largest number of crews departed in 1790 (maximum of 13 ships carrying 179 hunters). Unfortunately, this information has become available for us only after this paper was written, so the findings published by Dadykina, Kraikovski, and Lajus have not been commented on here in more detail. To assess the scale of Russian promysl in Svalbard one should also take into account the number of Pomor stations identified on the Svalbard coasts. According to the map published by V. F. Starkov (1998, fig. 36) these are 43 sites dated to the $17^{\text {th }}-18^{\text {th }}$ century, to which one should add a large station at Bettybukta on the eastern coast of Sørkappland, lacking in Starkov's publication (Ziaja 1993, 121-123).
} 
dryftowego - Häggblom 1982, 81-92; Eggertsson 1994, 4-8; Hellmann et al. 2013, 1-9), ile wzajemnych relacji czasowych pomiędzy różnymi obiektami i przejawami aktywności.

Przeprowadzenie takiego testu w postaci wykonania 26 analiz wyselekcjonowanych próbek drewna, reprezentujących wszystkie możliwe kategorie budulca i elementów rozbitych statków czy łodzi, pozwala stwierdzić, iż materiał budowlany jest również zróżnicowany pod względem gatunkowym (głównie Larix sp., ale też Pinus sp. i Picea sp.). Najbardziej popularnym materiałem budowlanym był modrzew (Larix sp.), który dominuje wśród przywożonych z kontynentu, gotowych do zmontowania ,prefabrykatów”. Dla niego uzyskano sekwencję liczącą 208 lat, pozwalającą synchronizować poszczególne przedsięwzięcia budowlane i określać ich charakter. Sekwencja uzyskana dla sosny (Pinus sp.), licząca 222 lat, synchronizuje z kolei działania budowlane z przejawami aktywności żeglarskiej Pomorców w tej części archipelagu. Ponieważ nie zdołano tych sekwencji wydatować w oparciu o dostępne chronologie absolutne drewna modrzewiowego i sosnowego, szansę na przybliżone ustalenie ich wieku dawały jedynie analizy radiowęglowe z wykorzystaniem metody dopasowania krzywych (wiggle-matching) (Bronk Ramsey et al. 2001, 381-389). Jako generalny rezultat przeprowadzonych w tym trybie analiz, należy przyjąć fakt, iż najwcześniejsze z uzyskanych oznaczeń dla najmłodszych słojów w analizowanych sekwencjach, nie są starsze niż przełom wieku XVII i XVIII AD.

W efekcie przeprowadzonych procedur badawczych, uzyskano - jak się wydaje - spójny obraz rozwoju pomorskiego promysla w północnej części Sørkapplandu. Relikty rosyjskich stacji łowieckich na wybrzeżach północnej części Sørkapplandu, ograniczonej od południa barierą lodowca Olsokbreen a od północy fiordem Hornsund, są pozostałością autonomicznego funkcjonalnie organizmu, którego genezę i historyczny rozwój cechuje wewnętrzna logika i racjonalność działań. W początkowym okresie aktywności, pomorscy żeglarze i łowcy penetrujący przybrzeżne łowiska południowego Spitsbergenu, wybrali na miejsce bazowe przylądek Palffyodden po południowej stronie wejścia do Hornsundu, wysunięty w morze i rzucający się w oczy charakterystycznym położeniem. Rejon Palffyodden usiany szkierami, skalistymi wysepkami i przylądkami, ale też zacisznymi plażami w małych zatoczkach, obfitował w siedliska morsów, był też zwornikiem, przez który prowadziły trasy wędrówki białych niedźwiedzi, choć nie zapewniał dogodnego, bezpiecznego kotwicowiska. Zapewne gdzieś w początkach XVIII wieku (około 1720?), zbudowano na Palffyodden pierwszy domek (chata A), usytuowany zresztą w miejscu niezbyt dogodnym, wystawionym na silne wiatry wiejące tak z morza, jak i fiordu. Strategiczne położenie spowodowało jednak, iż dla kolejnych generacji łowców stacja na Palffyodden stanowiła dogodny punkt wyjścia dla penetracji łowisk zlokalizowanych wzdłuż wybrzeża, tak w stronę fiordu Hornsund, jak i na południe, do bariery lodowca Olsok. Stąd sukcesywnie budowano tu kolejne chaty (chata C - około 1750-1760 i chata B - zapewne pod koniec XVIII wieku?), coraz to lepiej wkomponowywane w krajobraz i zabezpieczone przed uciążliwością warunków atmosferycznych (osłonięte ostańcami skalnymi). Długotrwałość i sukcesywność działań symbolizuje cmentarzyk założony w pobliżu zabudowań stacji, a użytkowany do ostatnich dziesięcioleci XVIII wieku. Intensyfikacja aktywności łowieckiej i kumulacja wiedzy dotyczącej warunków topograficznych, logistycznych - żeglugowych itp., w tej partii wybrzeży Sørkapplandu spowodowały, iż zapewne w ostatnich dziesięcioleciach XVIII wieku Pomorcy założyli tu nową stację zlokalizowaną w najdogodniejszym bodaj miejscu, na Schönningholmane, w sąsiedztwie znakomitego kotwicowiska w Arkeologvika lub w pobliskiej Gåshamna. Jest to równocześnie jeden z najbardziej charakterystycznych punktów krajobrazu Hornsundu, dogodny dla rozwijania działalności tak wzdłuż wybrzeża Sørkapplandu, jak i w głąb fiordu. Tym razem była to duża, jednorazowo zbudowana stacja bazowa, stanowiąca kompleksowe zaplecze dla zorganizowanej grupy (artelu) łowców. Jej placówkami pomocniczymi, poszerzającymi zasięg działalności łowieckiej, były zapewne: najmłodszy z budynków na Palffyodden (chata B) i - zbudowany specjalnie na południowych rubieżach rewiru - domek na Bjørnbeinflyene. Całe to przedsięwzięcie było nie tylko z góry zaplanowane i przeprowadzone z rozmachem, ale usankcjonowane sakralnie wznoszeniem obok stacji monumentalnych krzyży, zgodnie z normami właściwymi dla mentalności religijnej Pomorców, z przewagą zachowań właściwych 
dla konfesyjności staroobrzędowców. Obraz rozwoju rosyjskiego promysla w północnej części Sörkapplandu, zarysowany przy uwzględnieniu wartości poznawczych datowań dendrochronologicznych, jest więc zasadniczo zbieżny z ramami chronologicznymi tego procesu identyfikowanymi w oparciu o przesłanki historyczne (Arlov 1988, 140; Jasinski 1993, 35-36; Hultgreen 2000, 267-280; Dadykina et al. 2017, 50-69).

\section{References}

Albrethsen S. E., Arlov T. B., 1988 The discovery of Svalbard - a problem reconsidered, Fennoscandia archaeological, 5, pp. 105-110.

Arlov T. B., 1988 Svalbard 1596-1650 i historiografisk lys, Oslo.

Bojarskij P. V., Gusev S. V., Evseev V. F., Zakharov Ju. S., Kaljakin V. N., Korjakin V. S., Mazurov Ju. L., Serebrjannyj L. R., 1994 Kontseptsja formirovanija sistemy osobo okhranjaemykh prirodnykh i istoriko-kul'turnykh territorij na Novoj Zemle, (in:) P. V. Bojarskij (ed.), Novaja Zemlja, 3, Trudy Morskoj arkticheskoj kompleksnoj èkspeditsii, Moskva, pp. 12-37.

Braat J., 1984 Dutch Activities in the North and the Arctic during the Sixteenth and Seventeenth Centuries, Arctic, 37/4, pp. 473-480.

Bronk Ramsey C., van der Plicht J., Weninger B., 2001 'Wiggle-matching' radiocarbon dates, Radiocarbon, 43 (2A), pp. 381-389.

Carlheim-Gyllensköld V., 1900 På åttionde breddgraden. En bok den svensk-ryska gradmätningen på Spitsbergen, Stockholm.

Chernykh N. B., 1987 Nekotorye itogi dendrokhronologicheskogo izuchenija dereva postroek s arkhpelaga Shpitsbergen, (in:) J. Repelewska-Pękalowa, M. Harasymiuk, K. Pękala (eds.), XIV Sympozjum Polarne Lublin, pp. 252-259.

1988 The problem of dendrochronology of Russian buildings on Spitsbergen (- some notes regarding the discussion), Fennoscandia archaeological, 5, pp. 117-118.

1990 Rezultaty dendrokhronologicheskogo izuchenija dereva iz raskopok na arkhipelage Shpitsberegen (in:) V. F. Starkov, R. L. Rozenfel'd, V. I. Zavjalov (eds.), Ocherki istorii osvoenija Shpitsbergena, Moskva, pp. 107-123.

1996 Dendrokhronologia i arkheologija, Moskva.

Chochorowski J., 1988 Pomor settlement complexes in north-western Sørkappland (West Spitsberegen) in the light of Polish archeological exploration, Tromura, Kulturhistorie, 11, pp. 123-144.

1989 The Hornsund whaling station - exploration and conservation problems, Acta Borealia, 1-1989, pp. 21-42.

1989a Some major problems of the archaeological exploration of north-western Sørkapp Land (Spitsbergen), Prace Geograficzne 81, pp. 179-266.

1992 Dendrochronologie der russischen Jägerstationen auf Spitzbergen und historische Tatsachen, (in:)

J. Pusztay, E. Saveljeva (eds.), Specimina Sibirica, t. V, Savariae, pp. 53-62.

1999 Problems of the Dendrochronology of Russian Hunting Stations on Spitsbergen, Kraków. 
2002 The influence of changes of the natural environment on the state of preservation of archaeological monument complexes in Sørkappland, (in:) W. Ziaja, S. Skiba (eds.), Sørkappland landscape structure and functioning (Spitsbergen, Svalbard), Kraków, pp. 87-106.

2008 Odkrywcy i grabieżcy Spitsbergenu, Alma Mater, 99, pp. 245-251.

2012 Russian ortodox pendant crosses from Polish archaeological research on Spitsbergen, (in:) M. Salamon, M. Wołoszyn, A. Musin, P. Špeher (eds.), Rome, Constantinopole and Newly-Converted Europe. Archaeological and Historical Evidence, 2, Kraków - Leipzig - Rzeszów - Warszawa, pp. 655-680.

Chochorowski J., Jasinski M. E., 1988 Traces of Pomor nautical penetration on the coasts of northwestern Sørkappland, West Spitsbergen, Acta Borealia, 1988/1-2, pp. 50-69.

1993 Topography, Structure and Chronology of Russian Hunting Stations on the West Coast of Spitsbergen, (in:) M. E. Jasinski (ed.), Pomors in Grumant. Archaeological Studies of Russian Hunting Stations in Svalbard, vol. II, Trondheim - Tromsø, pp. 1-33 (112-144).

1993a Archaeology of Svalbard - Excavations of Russian hunting stations in the Hornsund area, Spitsbergen, (in:) M. E. Jasinski (ed.), Pomors in Grumant. Archaeological Studies of Russian Hunting Stations in Svalbard, vol. II, Trondheim - Tromsø, pp. 1-53 (59-111).

1995 Relics of Russian hunting stations on Dunöyane (West Spitsbergen), Polish Polar Research, 16 (3-4), pp. 267-280.

sir Conway M., 1906 No Man's Land. A History of Spitsbergen from its discovery in 1596 to the beginning of the scientific exploration of the Country, Cambridge (reprint, Oslo/Gjøvik, 1995).

Dadykina M., Kraikovski A., Lajus J., 2017 Mastering the Arctic Marine environment: organizational practices of Pomor hunting expeditions to Svalbard (Spitsbergen) in the eighteenth century, Acta Borealia. A Nordic Journal of Circumpolar Societies, 34(1), pp. 50-69.

Eggertsson Ó., 1994 Driftwood as an indicator of relative changes in the influx of Arctic and Atlantic Water into the coastal areas of Svalbard, Polar Research, 13 (2), pp. 209-218.

1994a Origin of the Arctic driftwood - a dendrochronological study, Lundqua Thesis, 32, pp. 1-13.

Filin P. A, Frizin N. N., 2001 Krest v promyslovoj kul 'ture pomorov Russkogo Severa, (in:) S. V. Gnutova (ed.), Stavrograficheskij Sbornik, 1, Moskva, pp. 166-198.

Grove J. M., 1988 The Little Ice Age, London - New York.

Hacquebord L., 1981 De walvisvaart: historie van een bedrjfstak, (in:) L. Hacquebord, R. de Bok (eds.), Spitsberegen $79^{\circ}$ N.B., Amsterdam - Brussel, pp. 9-43.

1984 Smeerenburg. Het verblijf Nederlandse walvisvaarders op de westkust van Spitsbergen in de 17 e eeuw, Amsterdam.

Heintz A., 1966 Russian opinion about the Discovery of Spitsbergen, Årbok 1964, Oslo, pp. 93-118.

Helberg B. H., 1998 Svalbards arkeologiske historie, Tromura. Kulturhistorie, 30, Tromsø.

Hellmann L., Tegel W., Eggertsson O., Schweingruber F. H., Blanchette R., Kirdyanov A., Gärtner H., Büntgen U., 2013 Tracing the origin of Arctic driftwood, Journal of Geophysical Research: Biogeosciences, 118, doi: 10.1002/jgrg. 20022, pp. 1-9. 
Höggblom A., 1982 Driftwood in Svalbard as an indicator of sea ice conditions, Geografiska Annaler, 64A (1-2), pp. 81-94.

Hultgreen T., 2000 (2003) Den russiske fangsten på Svalbard. En reanalyze av arkeologiske og historiske kilder, Tromsø.

Jasinski M. E., 1993 Russian hunting in Svalbard - the fourth model, (in:) M. E. Jasinski, Pomors in Grumant. Archaeological Studies of Russian Hunting Stations in Svalbard, vol. II, Trondheim - Tromsø, pp. 1-75 (191-266).

Johansen S., 1998 The origin and age of driftwood on Jan Mayen, Polar Research, 17 (2), pp. 125-146.

Jørgensen R., 2017 Slutten på en epoke. Pomorenes fangststasjonen på Kapp Lee, Svalbard, Viking, Norsk Arkeologisk Årbok, 80, pp. 203-222.

Keilhau B. M., 1831 Reise i Öst- og Vest-Finmarken samt til Beeren-Eiland og Spitsbergen I Aarene 1827 og 1828 , Christiania.

Kirchhefer A., 2000 (2003) Dendrokronologisk datering av fangsthytter på Svalbard v/Chernyk 1987 og 1990, (in:) T. Hultgreen (ed.), Den russiske fangsten på Svalbard. En reanalyze av arkeologiske og historiske kilder, Tromsø, pp. 323 (1-4).

Koltjakov V. M., Gordienko F. G., 1982 Izotopnaja i geokhimicheskaja gljatsiologija, Leningrad.

Krawczyk A., 1995 Data for the history of the Dunöyane, Spitsbergen, Polish Polar Research 16 (3-4), pp. 281-288.

Krawczyk A., Krąpiec M., 1995 Dendrochronologiczna baza danych, Materiały II Krajowej Konferencji: Komputerowe wspomaganie badań naukowych, Wrocław, pp. 247-252.

von Löwenigh B., 1989 Barto von Löwenigh, (in:) G. Grümmer (ed.), Nördlich von Europa. Reisen deutschsprachiger Forscher nach Grönland, Spitzbergen und anderen Inseln der Arktis in den Jahren zwischen 1760 und 1912, Berlin, pp. 115-124.

Lønø O., 1991 Norske fangstmenns overvintringer på Svalbard, Jan Mayen og Frans Josef Land, Oslo.

Odintsov V. A., Starkov V. F., 1985 Nekotorye problemy arkticheskogo moreplavanija i pochody russkikh na archipelag Shpitsbergen, Letopis Severa, 11, pp. 147-161.

Ovsjannikov O. V., Starkov V. F., 1982 Rabota sovetskoj arkheologicheskoj èkspeditsii na arkhipelage Shpitsbergen, Priroda i Khozjajstvo Severa, 10, pp. 72-86.

1985-1986 Russernes arkeologiske aktivitet fra 1978-80, (in:) B. Amundsen (ed.), Svalbard Boka 198586, Oslo, pp. 121-133.

Reimer P. J., Bard E., Bayliss A., Beck J. W., Blackwell P. G., Bronk Ramsey C., Buck C. E., Cheng H., Edwards R. L., Friedrich M., Grootes P. M., Guilderson T. P., Haflidason H., Hajdas I., Hatt E. C., Heaton T. J., Hoffmann D. L., Hogg A. G., Hughen K. A., Kaiser K. F., Kromer B., Manning S. W., Niu M., Reimer R. W., Richards D. A., Scott E. M., Southon J. R., Staff R. 
A., Turney C. S. M., van der Plicht J., 2013 IntCal13 and Marine13 radiocarbon age calibration curves 0-50,000 years cal BP, Radiocarbon, 55 (4), pp. 1869-1887.

Rinn F., 2005 TSAP-Win. Time series analysis and presentation for dendrochronology and related applications. User Reference, Heidelberg.

Rossnes G., 1990 “Den statistiske fangstmann”. Norsk overvintringsfangst på Svalbard 1895-1940, (in:) Forskning om mennesker på Svalbard. Rapport fra et seminar 3.-6. Mai 1989, Oslo, pp. 71-94.

Schilder G., 1988 Spitsbergen in de spiegel van de kartografie. Een verkenning van de ontdekking en kartering, (in:) L. Hacquebord, I. W. Vroom (eds.), Walvisvaart in de Gouden Eeuw. Opgravingen op Spitsbergen, Amsterdam, pp. 30-48.

Starkov V. F., 1987 Russkoe arkticheskoe moreplavanie i pokhody na Shpitsbergen v XVI veke, (in:) J. Repelewska-Pękalowa, M. Harasymiuk, K. Pękala (eds.), XIV Sympozjum Polarne, Lublin, pp. 236-241.

1988 Russian sites on Spitsbergen and the problem of chronology, Fennoscandia archaeological, 5, pp. 111-116.

1990 Khronologija i periodizatsija russkikh pamjatnikov na Shpitsbergene, (in:) V. F. Starkov, R. L. Rozenfel'd, V. I. Zavjalov (eds.), Ocherki istorii osvoenija Shpitsbergena, Moskva, pp. 124-133.

1998 Ocherki istorii osvoenija Arktiki, t. I. Shpitsbergen, Moskva.

2008 Udalennye severorusskie promysly v sisteme pomorskoj kul'tury XVI-XVIII vv., (in:) M. P. Chernaja (ed.), Vremja i kul'tura $\mathrm{v}$ arkheologo-ètnograficheskikh issledovanijakh drevnikh i sovremennykh obshchestv Zapadnoj Sibiri i sopredel'nykh territorij: problemy interpretatsii i rekonstruktsii, Tomsk, pp. 247-251.

2012 Novye dannye o severorusskikh sudakh XVI-XVIII w. (in:) V. V. Bobrov et al. (eds.), Arkheologoètnograficheskie issledovanija Severnoj Evrazii, Tomsk, pp. 227-232.

Starkov V. F., Chernosvitov P. Ju., 1990 Ostatki sudna na ostrove Printsa Karla, (in:) V. F. Starkov, R. L. Rozenfel'd, V. I. Zavjalov (ed.), Ocherki istorii osvoenija Shpitsbergena, Moskva, pp. 168-181.

Starkov V. F., Korjakin V. S., Zav’jalov V. I., 1983 Russkie poselenija XVI v. na Shpitsbergene, Vestnik Akademii Nauk SSSR, 12/1983, pp. 109-113.

Storå N., 1987 Russian Walrus Hunting in Spitsbergen, Études Inuit Studies, 11(2), pp. 117-137.

Tegengren H., 1962 Der Handel mit Walroßzähnen und die russischen Fangstationen auf Spitzbergen im 17. und 18. Jahrhundert, Deutsches Jahrbuch für Volkskunde, 8(2), pp. 312-337, pl. 23-26.

Zav'jalov V. I., Starkov V. F., 1987 Arkheologicheskie pamjatniki ostrova Serkap (arkhipelag Shpitsbergen), (in:) J. Repelewska-Pękalowa, M. Harasymiuk, K. Pękala (eds.), XIV Sympozjum Polarne, Lublin, pp. 242-248.

Ziaja W., 1993 Discovery of remains of settlement in Bettybukta, SE Sørkapp Land, Spitsbergen, (in:) J. Repelewska-Pękalowa, K. Pękala (eds.), XX Polar Symposium, Lublin, pp. 121-123.

1995 Enviromental Changes and Remains of Human Activity in the South-Eastern Spitsbergen, Il Polo. Revista Trimestrale dell'Istituto Geografico Polare "Silvio Zavatti”, 4, pp. 38-43. 